This report was prepared as an account of work sponsored by an agency of the United States Government. Neither the United States Government nor any agency thereof, nor any of their employees, makes any warranty, express or implied, or assumes any legal liability or responsibility for the accuracy, completeness, or usefulness of any information, apparatus, product, or process disclosed, or represents that its use would not infringe privately owned rights. Reference herein to any specific commercial product, process, or service by trade name, trademark, manufacturer, or otherwise does not necessarily constitute or imply its endorsement, recommendation, or favoring by the United States Government or any agency thereof. The views and opinions of authors expressed herein do not necessarily state or reflect those of the United States Government or any agency thereof.

\title{
HEPA FILTER LEACHING CONCEPT VALIDATION TRIALS AT THE IDAHO CHEMICAL PROCESSING PLANT
}

\author{
Ambika C. Chakravartty
}

Published April 1995

\section{Idaho National Engineering Laboratory Lockheed Idaho Technologies Company \\ Idaho Falls, Idaho 83415}

\author{
DISTRIBUTIO
for the \\ Prepared for the \\ U.S. Department of Energy \\ Assistant Secretary for Environmental Management \\ Under DOE Idaho Operations Office \\ Contract DE-AC07-941D13223
}




\section{DISCLAIMER}

Portions of this document may be illegible in electronic image products. Images are produced from the best available original document. 


\section{ABSTRACT}

The enclosed report documents six New Waste Calcining Facility (NWCF) HEPA filter leaching trials conducted at the Idaho Chemical Processing P1ant using a filter leaching system to validate the filter leaching treatment concept. The test results show that a modified filter leaching system will be able to successfully remove both hazardous and radiological constituents to RCRA disposal levels. Based on the success of the filter leach trials, the existing leaching system will be modified to provide a safe, simple, effective, and operationally flexible filter leaching system. 
. 


\section{SUMMARY}

Six New Waste Calcining Facility (NWCF) spent HEPA filters were leached using the existing filter leaching system to validate the HEPA filter leaching treatment concept developed at the Idaho Chemical Processing Plant (ICPP). The leaching system includes three leach cycles in $1-3 \mathrm{M}$ nitric acid at $176^{\circ} \mathrm{F} \pm 15^{\circ} \mathrm{F}$ for 40 minutes per cycle, followed by two water rinse cycles at ambient temperature for 15 minutes per cycle. During the leaching process, minor operational problems were experienced. (Modifications to correct these problems are expected to start in early 1995.)

Post-leach filter media sampling results for all six NWCF spent filters show that both hazardous and radiological constituents levels were reduced and that the filters can be disposed of as low-level radiological waste.

The liquid waste volume generated during the filter leaching trials using the existing system averaged 678 gallons for each filter. After the existing system is modified, the liquid waste volume generation will be reduced by approximately 225 gallons per filter. In addition, the modified leaching system will be designed to leach all filter sizes including Waste Calcining Facility (WCF), Special Power Excersion Reactor Test (SPERT), Fluorinel Dissolution Process (FDP), and NWCF spent filters.

Chemical analysis of the leachate and rinsate samples from cell drain hold tank VES-NCD-123 revealed that chloride concentration in the liquid waste was higher for filters \#2 and \#5 and did not meet the Process Equipment Waste (PEW) evaporator acceptance criteria. Liquid waste analysis of the leachate and rinsate for filters \#1, 3, 4, and 6 met PEW evaporator acceptance criteria. It is suggested that the leachate and rinsate solution of VES-NCD-123 be mixed with similar waste to reduce chloride concentration for disposal to the PEW evaporator. Assuming the composite samples of leachate and rinsate will meet the PEW evaporator acceptance criteria, it is estimated that only 15 gallons of waste solution from the PEW evaporator bottoms per treated filter will go to the tank farm during leaching in the modified system. 
The average leaching time is approximately ten hours for each large filter. With no anticipated delays, and considering equilpment downtime and intermittent operation of the leach system (assuming $50 \%$ downtime), it is estimated that eight large filters could be leached per month in the modified leaching system. 


\section{ACKNOWLEDGEMENTS}

The author wishes to thank D. S. Andreason, D. D. Grover, S. R. Gokey, W. K. Kline, K. F. Smith, and K. R. Shackelford for their outstanding efforts in the operations of the filter leach trials. For valuable technical exchange, the author also thanks K. N. Brewer, C. W. McCray, and K. L. Shifty. It was a particularly pleasurable experience to discuss the filter leach project with former Section Manager, J. G. Burton, and receive her guidance and support. Special thanks are due to M. R. Greene, Supervisor of the Decontamination Facility, for his direct participation and effective $p l$ anning in the Filter Leach Project. Finally, the author wishes to acknowledge the contributions made by R. L. Lane, R. A. Braga, and R. B. Morgan for the remote tool design and technical assistance on the project; to Dr. S. V. Raman of the Waste Form Development Group for the optical microscopy of the HEPA filter; to L. A. Powell, who translated the original manuscript with care and word processing skills; and to M. T. Hamilton, who edited and prepared the final manuscript for printing. 


\section{CONTENTS}

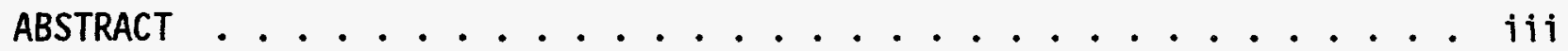

SUMMARY ........................ v

ACKNOWLEDGEMENTS .............................. vi

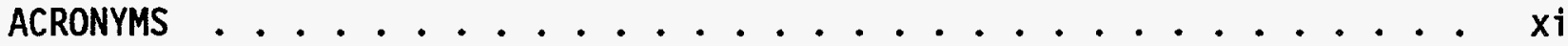

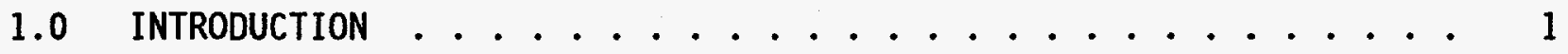

2.0 CONCEPT VALIDATION TRIALS . . . . . . . . . . 7

3.0 LEACHING SYSTEM DESCRIPTION . . . . . . . . . . . . 8

4.0 OPERATION OF EXISTING SYSTEM .............. 10

5.0 LEACHING OF NWCF SPENT FILTERS . . . . . . . . . . . 12

5.1 Leaching of Filter \#1 .............. 13

5.2 Leaching of Filter \#2 ............... 14

5.3 Leaching of Filter \#3 ............... 15

5.4 Leaching of Filter \#4.............. 15

5.5 Leaching of Filter $\# 5 \ldots . . . \ldots . . . . . . .16$

5.6 Leaching of Filter $\# 6 \ldots \ldots 16$

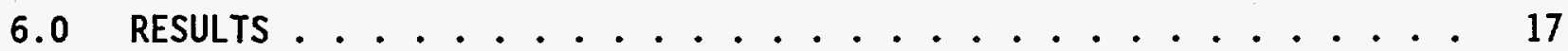

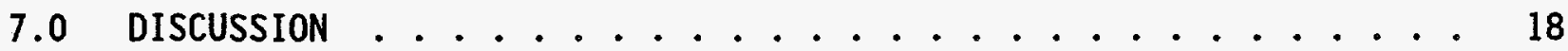

8.0 MODIFICATION OF PRESENT SYSTEM ............... 20

9.0 FILTER THROUGHPUT ................... 23

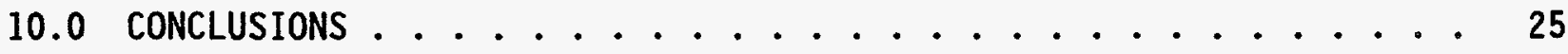

11.0 RECOMMENDATIONS . . . . . . . . . . . . . . 25

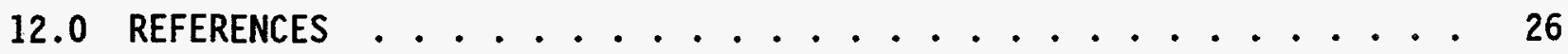

Appendix A--Filter Leach Trials Data .............. A-1

Appendix B--Design of Leach Basket and Support Frame ......... B-1 


\section{FIGURES}

1. Typical HEPA filter ...................... . . . 2

2. Photomicrograph of the HEPA filter media ............. 3

3. Decontamination area plan view ............... 5

4. Existing filter handling cell ................. 6

5. Existing filter leaching system ................... 9

6. Modified filter leaching system plan view . . . . . . . . . . 21

7. Modified filter leaching system flow chart . . . . . . . . . . 24

B-1. Sketch of assembled basket ................. B-3

B-2. Sketch of basket bail . . . . . . . . . . . . . . . B-4

B-3. Plan view of basket top assembly (screen and bail

omitted for clarity) ................... . B-5

B-4. Plan view of base assembly (screen omitted for clarity) . . . . . B-6

B-5. Isometric sketch of folded sheet metal box . . . . . . . . . B-7

B-6. 3-D Isometric view of base assembly (screen omitted for clarity) . B-8

B-7. Side view of basket support assembly (bail omitted for clarity). . B-9

B-8. Top view of basket support assembly . . . . . . . . . . . B-10

B-9. Section view through side of basket support (bai1 omitted) . . . B-11

B-10. Detail of top frame of basket support ............... B-12

B-11. Detail of bottom frame of basket support . . . . . . . . . . B-13

B-12. Sketch of bail assembly for basket support . . . . . . . . . B-14

\section{TABLES}

1. Maximum TCLP limits . . . . . . . . . . . . . . . . 4

2. Nitric acid molarity for filter leach . . . . . . . . . . . . 12

3. Number of spent HEPA filters currently at the ICPP . . . . . . . 22

4. Pre-leach filter condition ............... A-3

5. Post-leach filter drying parameters, filter media conditions and sampling ................ . . A-4

6. HEPA filter leach/rinse cycles (Filter 1) .......... . A-5

7. HEPA filter leach/rinse cycles (Filter 2) ........... A-6

8. HEPA filter leach/rinse cycles (Filter 3) . . . . . . . . . A-7

9. HEPA filter leach/rinse cycles (Filter 4) . . . . . . . . . A-8

10. HEPA filter leach/rinse cycles (Filter 5) ............ A-9

11. HEPA filter leach/rinse cycles (Filter 6) . . . . . . . . . . . A-10

12. Acid/water volume consumed and waste volume generated

during filter leach ........................A-11

13. Analysis of leachate and rinsate from VES-NCD-123 . . . . . . A-12

14. Filter handling and leaching time ............... A-13

15. Activity schedule for batch throughput . . . . . . . . . . A-14

16. TRU results on HEPA filter media ................ A-15

17. Six HFLS filter media samples analyzed for RCRA metals in 1994 . . A-16

18. Six HFLS filter rinsate samples analyzed in 1994 for RCRA metals . A-17

19. HFLS 1994 six filter media samples ran for total

analysis by GC/MS ...................... . . . . . . . . . . . .

20. HFLS 1994 initial six filter media samples extracted by ZHE

and analyzed by GC/MS ........................ . . . 


\section{TABLES (CONT.)}

21. HFLS 1994 filter media samples repulled and ran for total

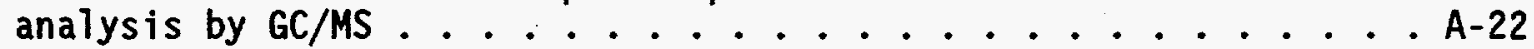

22. Six HFLS filter leachate/rinsate samples analyzed in 1994

for RCRA volatile organic carbons . . . . . . . . . . . . A-24

23. Six HFLS filter media samples analyzed for RCRA semi-volatile

$$
\text { organic carbons in } 1994 \text {. . . . . . . . . . . . . . A-26 }
$$

24. Six HFLS filter leachate/rinsate samples analyzed in 1994 for

RCRA semi-volatile organic carbons ............... A-28

25. HEPA filter leaching system (HFLS) initial six filter last process rinse sample ......................... 


\section{ACRONYMS}

$\begin{array}{ll}\text { CMA } & \text { Crane Maintenance Area } \\ \text { FDP } & \text { Fluorinel Dissolution Process } \\ \text { HEPA } & \text { High Efficiency Particulate Air } \\ \text { Hg } & \text { Mercury } \\ \text { HFLS } & \text { HEPA Filter Leach System } \\ \text { ICPP } & \text { Idaho Chemical Processing Plant } \\ \text { INEL } & \text { Idaho National Engineering Laboratory } \\ \text { NWCF } & \text { New Waste Calcining Facility } \\ \text { PTS } & \text { Pneumatic Transport System } \\ \text { PEW } & \text { Process Equipment Waste } \\ \text { RWMC } & \text { Radioactive Waste Management Complex } \\ \text { RAL } & \text { Remote Analytical Laboratory } \\ \text { RCT } & \text { Radiological Control Technician } \\ \text { RCRA } & \text { Resource Conservation and Recovery Act } \\ \text { SPERT } & \text { Special Power Excersion Reactor Test } \\ \text { SVOC } & \text { Semi-Volatile Organic Compound } \\ \text { TC } & \text { Toxic Characteristic } \\ \text { TRU } & \text { Transuranic } \\ \text { TCLP } & \text { Toxic Characteristics Leaching Procedure } \\ \text { VOC } & \text { Volatile Organic Compound } \\ \text { WCF } & \text { Waste Calcining Facility } \\ \beta & \text { Beta radiation } \\ \gamma & \text { Gamma radiation }\end{array}$




\section{HEPA FILTER LEACHING CONCEPT VALIDATION TRIALS AT THE IDAHO CHEMICAL PROCESSING PLANT}

\subsection{INTRODUCTION}

This report describes the nitric acid leaching of six spent New Waste Calcining Facility (NWCF) high efficiency particulate air (HEPA) filters to validate the modified filter leaching concept developed at the Idaho Chemical Processing P1 ant ${ }^{1}$ (ICPP) within the Idaho National Engineering Laboratory (INEL). HEPA filters are used to remove radioactive and hazardous contaminants. Contaminated HEPA filters are generated in the final stages of the calciner off-gas cleanup system and in similar off-gas clean up systems throughout the INEL.

A cross-section view of a typical HEPA filter is presented in Figure 1. An optical photomicrograph of the HEPA filter media is shown in Figure 2. The corrugated filter media is a mixture of fire resistant glass fibers, special acid-resistant material (Kevlar/Nomax), and a chemical binder. The corrugated media is folded back and forth and sealed on the edges of the metal housing with high temperature resistant silicone. The typical filter housing is made of 14 gauge 300 series austenitic stainless steel. Most filters have a plastic mesh on the top and a stainless steel screen on the bottom to ensure the filter media remains intact.

Contaminated spent HEPA filters are transuranic mixed waste. Untreated HEPA filters could be disposed of at the Waste Isolation Pilot Plant (WIPP) facility as transuranic mixed waste, but the limited storage space and high disposal costs make alternate disposal methods highly desirable. Disposal at the Radioactive Waste Management Complex (RWMC) at the INEL would be more cost effective. However, RWMC cannot accept contaminated filters unless transuranic, radioactive, and hazardous contaminants are below regulatory limits. Nitric acid leaching is regarded as an effective tool to remove these contaminants.

The purpose of the HEPA Filter Leaching System (HFLS) is to reduce transuranic and radioactive contaminant levels in the spent HEPA filters to allow disposal as low-level radioactive waste at the RWMC. The existing filter leach 


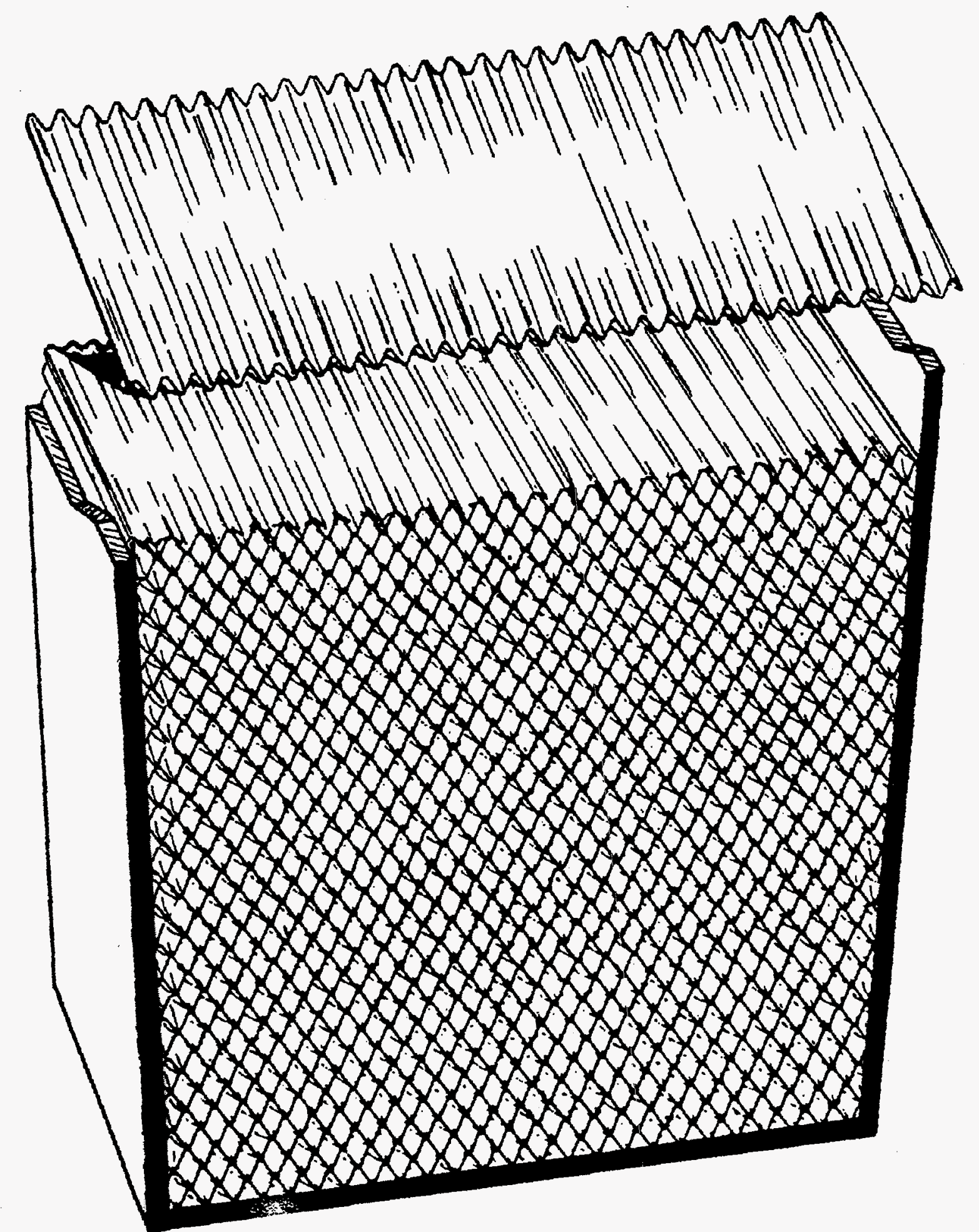

Figure 1. Typical HEPA filter. 

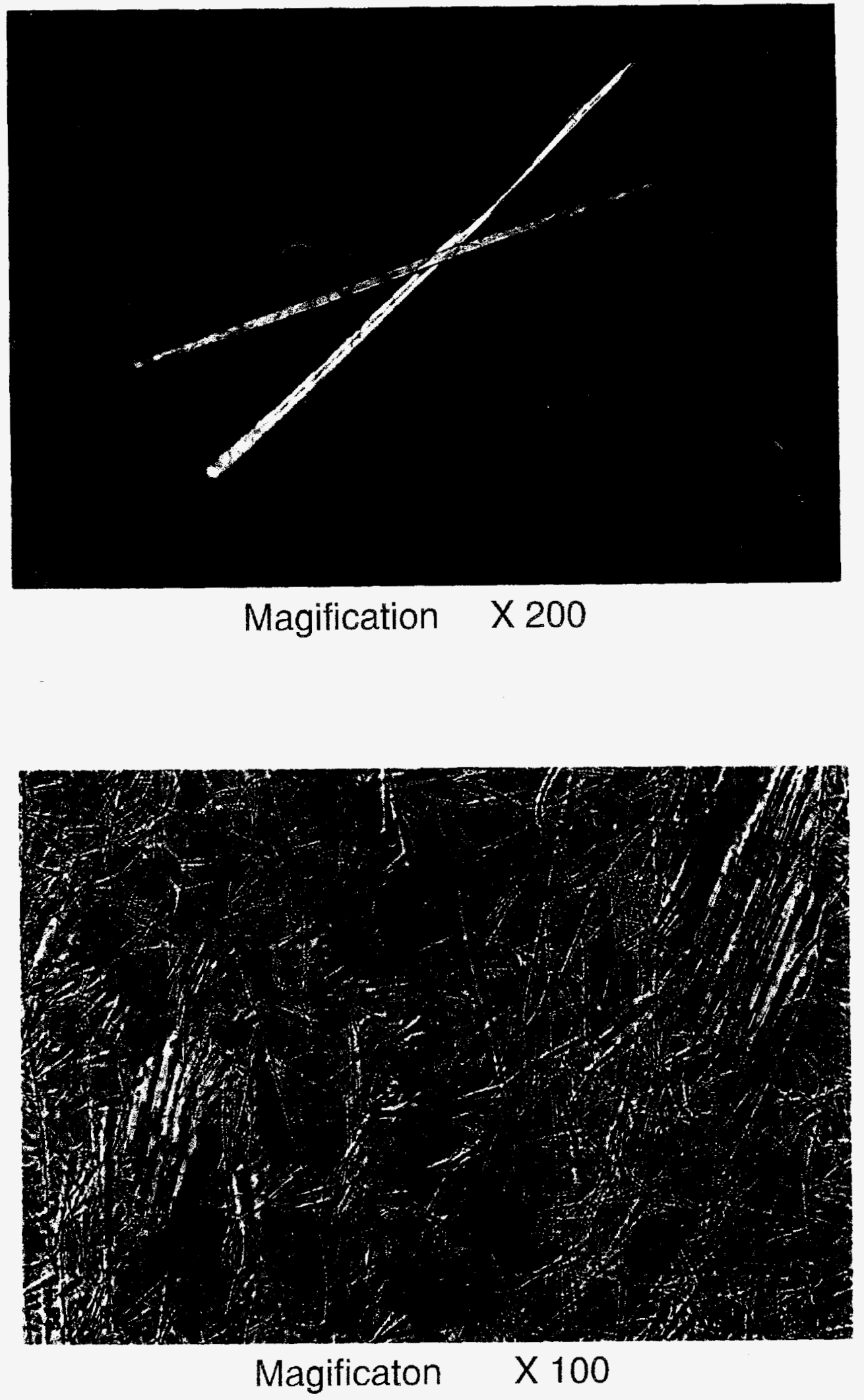

Figure 2. Photomicrograph of the HEPA filter media (Courtesy of Dr. S. V. Raman, Waste Form Development Group). 
system was built and installed in mid-1988 in the filter handling cell in the decontamination area of the NWCF (see Figures 3 and 4). The Resource Conservation and Recovery Act (RCRA), 40 CFR parts 260 through 270, requires removal of hazardous materials from solid waste prior to disposal as non-hazardous low-level radioactive waste. Hazardous materials limits are specified in the Toxic Characteristic Leaching Procedure (TCLP) and are indicated in Table 1 below:

Table 1. Maximum TCLP limits.

\begin{tabular}{|c|c|}
\hline Toxic Metal & Concentration (ppm) \\
\hline Arsenic & 5 \\
\hline Barium & 100 \\
\hline Cadmium & 1 \\
\hline Chromium & 5 \\
\hline Lead & 5 \\
\hline Mercury & 0.2 \\
\hline Selenium & 1 \\
\hline Silver & 5 \\
\hline
\end{tabular}

Initial testing of the HFLS indicated that leaching would reduce transuranic elements as well, as most hazardous contaminants to regulatory disposal 1 imits but would not consistently remove mercury and cadmium to acceptable levels. Moreover, severe operational problems were experienced during the initial leaching trials ${ }^{1}$. Filter media was partially destroyed and pieces of the filter media plugged the vessel drain and clung to the interior of the leach vessel. A testing effort was initiated to optimize leaching process parameters so that RCRA disposal limits could be met and the operational problems experienced during the previous trial could be eliminated ${ }^{2}$.

The ICPP designed, built, and tested a HFLS mock-up in the pilot plant area of the CPP-637 high bay. The leaching system was designed to perform testing on Fluorinel Dissolution Process (FDP) filters which measure 8 inches $\times 8$ inches $x$ 6 inches. These filters were contaminated with hazardous constituents but were not radioactive. 


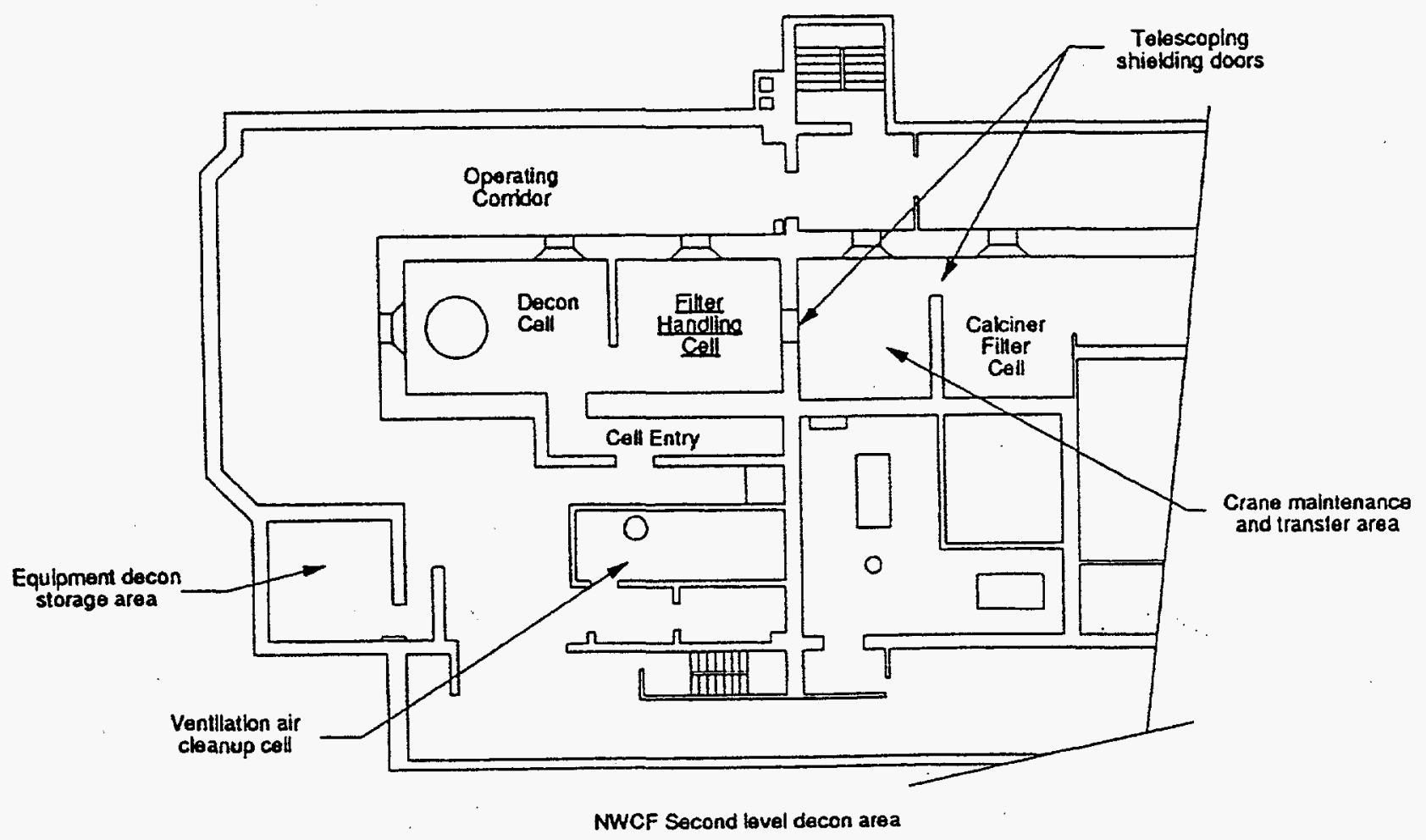

Figure 3. Decontamination area plan view. 


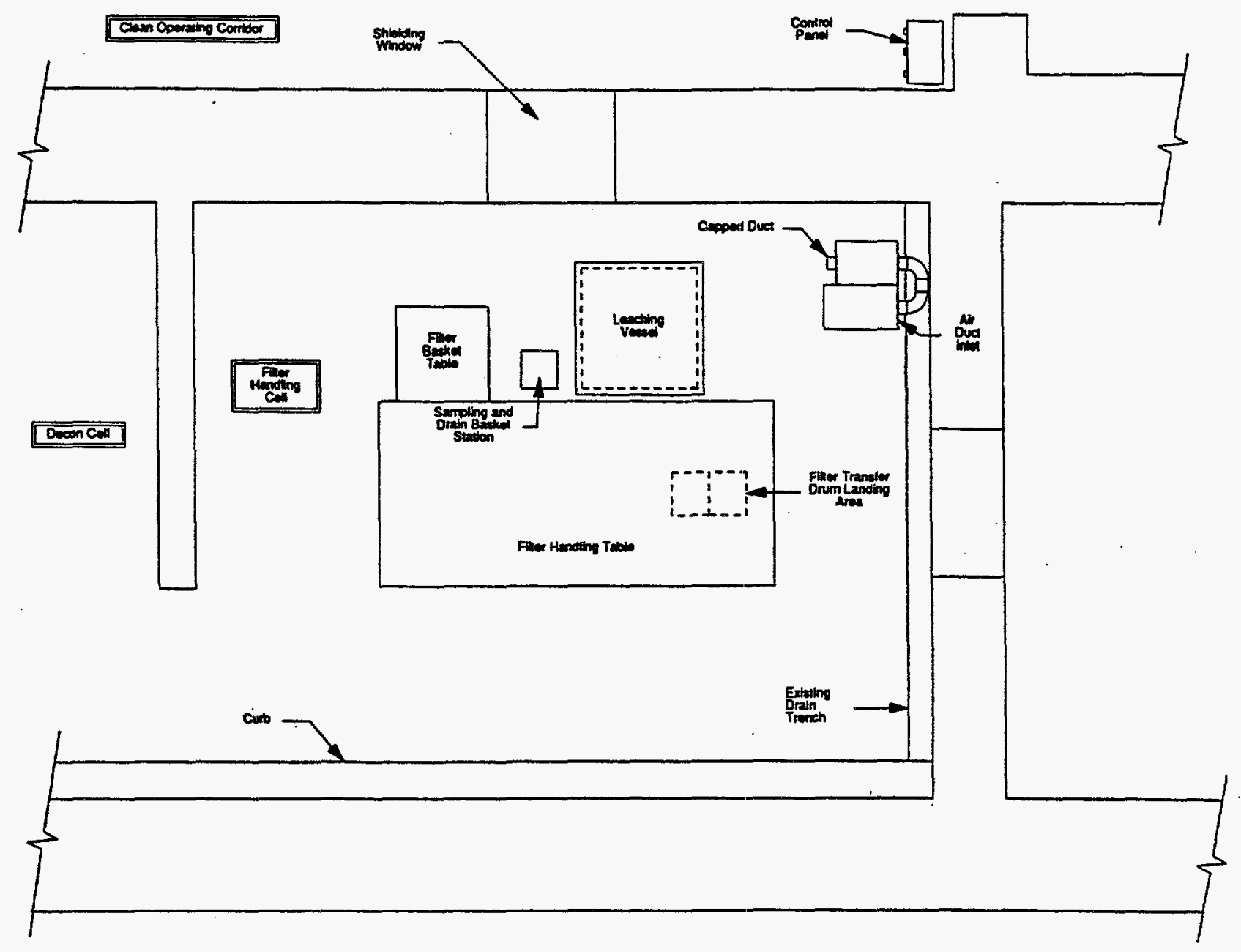

Figure 4. Existing filter handling cell. 
This developmental work identified process parameters that allowed satisfactory leaching of filters to meet RCRA disposal criteria. The test results also indicated that the original method of leaching filters should be modified. The filters should be placed face down in the leaching vessel, (stainless steel screen side up) and only one filter should be leached at a time. The filter media should be breached prior to leaching, to aid in the leaching process. Recirculation of the nitric acid is not necessary during leaching, but air sparging might be necessary to promote agitation. The nitric acid molarity should be in the range of 1-3M. The leach solution temperature should be approximately $176^{\circ} \mathrm{F}$ during start-up of the leach operation. It was also recommended that five leach cycles and two rinse cycles be used. These test results and recommendations were confirmed by leaching NWCF hot filters using the existing leach facility with the modified operating parameters. This report describes the validation trials which were conducted in the existing leaching facility at NWCF.

\subsection{CONCEPT VALIDATION TRIALS}

HEPA filter leaching tests were conducted in the existing filter leaching system to validate the modified HEPA filter leaching treatment concept. Six spent radioactive NWCF HEPA filters were leached. After treatment in the existing HFLS, representative filter media samples were collected and transported to the Remote Analytical Laboratory (RAL) for analysis.

The purpose of the analysis was to show that treated filters were not characteristically and radiologically hazardous and to obtain data on any organic residuals. The analysis tested TCLP metal and selected volatile organic levels. The organics that were analyzed correspond to waste codes that are not "soluble to at least $5 \%$ by weight in the water solution or $5 \%$ by weight in the emulsion, as applicable" (57FR 37230, August 18, 1992). The results of these tests indicated that the extent of contamination by these organics was extremely small, and the HEPA filter was no longer considered hazardous and could be disposed of as low-level radioactive waste. The results will be submitted to the State of Idaho for a regulatory determination. A regulatory determination for this treatment methodology is supported by a new regulatory provision to exclude low-hazard debris from subtitle $C$ regulations under those circumstances. [40 CFR 261.3(f)(2), 57 FR 37264]. 
During the filter leach treatment validation trial, the following process parameters were selected by the Operations Department after reviewing the HEPA filter leach system technical base report ${ }^{1}$. Leaching of filters included three leach cycles in $1-3 \mathrm{M}$ nitric acid at $176^{\circ} \mathrm{F} \pm 15^{\circ} \mathrm{F}$ for 40 minutes per cycle, followed by two water rinses at ambient temperature for 15 minutes per cycle. The acid and water volume should just submerge the HEPA filter during leaching and rinsing cycles with an air sparge rate of 12 to $30 \mathrm{scfm}$ to promote agitation. No circulation of acid or water was required. The filters were air dried at $425^{\circ} \mathrm{F}$ for 12 to 18 hours.

\subsection{LEACHING SYSTEM DESCRIPTION}

The previous leaching trials ${ }^{2}$ conducted at the filter handling cell produced severe filter media disintegration during leaching. The disintegrated, loose filter media caused severe plugging of the leach vessel drain line. It was decided that during this leaching trial, each filter would be placed in a disposable basket which completely encompassed the filter to preclude vessel drain plugging during leaching. The top and bottom of the basket was constructed of 14 mesh stainless steel screens with 0.053 inch openings to retain the loose filter media. Appendix $B$ shows the detailed design of the leach basket along with the support frame.

The existing filter leaching system is shown in Figure 5 and consists of a leaching vessel, two work tables, and associated piping and instrumentation. The leach vessel and work tables are located in the filter handling cell. Piping lines pass through the cell wall to utility service lines in the clean operating corridor. Remote handling capabilities are available within the cell via a pair of master-slave manipulators located on either side of the window, an overhead crane, and an electro-mechanical PaR with a robotic arm.

The filter leaching vessel (VES-NCD-155) is fabricated from 304L stainless steel and has a capacity of 175 gallons with a normal working volume of 110 gallons. The outside dimensions of the vessel are approximately 43 inches $x 43$ inches $\times 60$ inches high. The interior of the vessel measures 30 inches $x$ 30 inches $\times 45$ inches deep. The bottom 8 inches of the vessel cannot be used for leaching because of piping interferences. The floor of the leaching vessel is sloped to the vessel drain, which is then piped through a screen basket into a 


\section{Filter Leaching System}

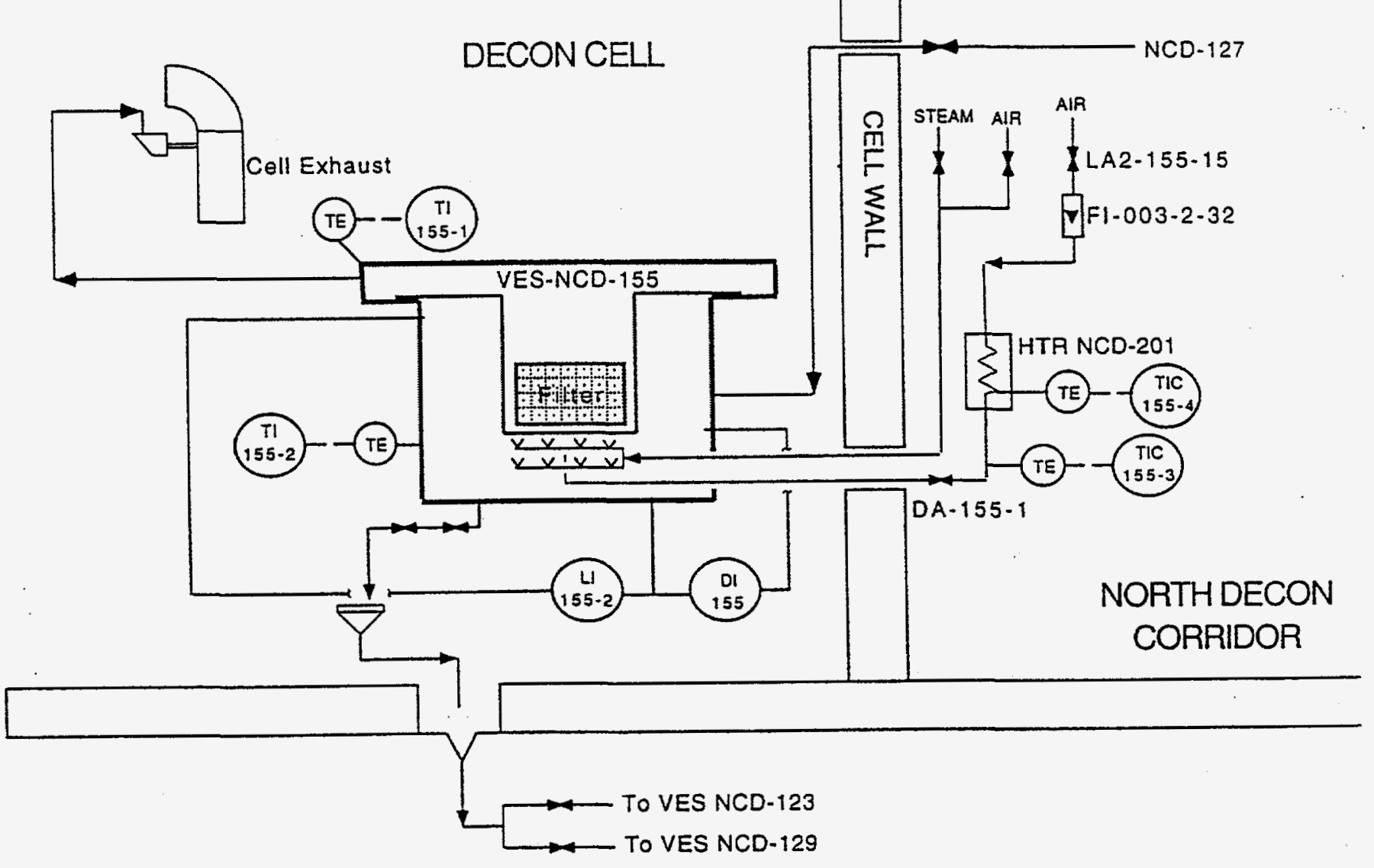

Figure 5. Existing filter leaching system. 
cell drain via the cell drain trench. There are pipes into the lower section of the vessel to allow it to be filled with nitric acid or water, sparged with steam or air, or dried with heated air. Other connections into the lower sections of the vessel include three air lifts, a sample port, level/density port, and a thermowel1. The top portion of the vessel includes piping connections for venting, overflow, and level indications. A second thermowell is also located at the top of the vessel. The leaching vessel has a removable lid which fits tightly on the vessel so that a slight vacuum is maintained in the vessel by the ventilation system during leaching, rinsing, and drying cycles.

The sampling station is located next to the filter leaching vessel and is designed for pulling liquid samples from the leach vessel. Process samples (water rinse \#2) are taken from the sampling station and hand-carried to the Remote Analytical Laboratory (RAL) under Radiological Control Technician (RCT) escort. Liquid wastes are collected in cell drain hold tank VES-NCD-123 where RCRA samples are taken remotely and sent to the RAL for analysis via the pneumatic transfer system (PTS).

The filter handling table is located behind the leaching vesse 7 and is directly under the filter handling cell hatch cover. The dimensions are 10.75 feet $\times 5$ feet $\times 5.5$ feet high. The table is constructed of stainless steel with an open grating working surface. It serves as the primary work surface for filter handling operations.

\subsection{OPERATION OF EXISTING SYSTEM}

This section describes how the existing leach system is operated to leach spent radioactive filters.

A contaminated filter is transferred into the filter handling cell through the PaR parking area and shielding doors using the filter handling tool and decon cell crane. The filter is then placed inside the top half of the leaching basket so that the stainless screen side is facing upward. The open leach basket is placed on the filter handling table. The filter is then mechanically breached using a breaching tool to make holes in the filter media for effective leaching and rinsing operations. The lid of the basket is then closed and locked using 
the cell crane, PaR, or manipulator. The leach basket and filter are then placed on the basket support inside leaching vessel VES-NCD-155.

1-3M nitric acid is made up in VES-NCD-127 where it is heated to $110^{\circ} \mathrm{F} \pm 15^{\circ} \mathrm{F}$. The volume of the acid per leach cycle is estimated to be approximately 140 gallons which is enough to submerge the HEPA filter. The leaching operation begins when the acid solution is transferred to the leach vessel and heated by steam to $176^{\circ} \pm 15^{\circ} \mathrm{F}$ keeping the vessel lid closed. Air sparging at $12 \mathrm{scfm}$ is initiated immediately. The filter is leached for 40 minutes. The leachate waste solution is then drained to VES-NCD-123. Second and third leach cycles follow the first leach cycle.

After completion of the three leach cycles, two water rinses are conducted at ambient temperature for 15 minutes each. The volume of water per rinse cycle is approximately 130 gallons. The last rinsate sample is collected from the leach vessel sample port and the rinsate is drained to VES-NCD-123.

After transferring all leachate and rinsate to VES-NCD-123, liquid composite samples are collected from VES-NCD-123 for RCRA characterization through dedicated sampling station SAM-NCC-620 and sent to the RAL via the PTS for analyzing TC Metals, VOC/SVOC, Hg, TRU, and acidity.

After completion of the leaching and rinsing cycles, the filter is dried in the leaching vessel. The drying operation is performed by forcing air through an air heater to raise the air temperature to $425^{\circ} \mathrm{F}$. The air is then forced into the bottom of the vessel, through the filter, and out to the vent at the top of the leach vesse1. The drying air temperature is controlled by a thermocouple downstream of the air heater. Two additional thermocouples monitor the air temperature at the leaching vessel air inlet and the leaching vessel vent outlet. Drying time is 12 to 18 hours.

After the filter is dried, the leaching basket containing the leached filter is removed from the leaching vessel by the cell crane and placed on the filter handling table for media sampling. The basket is rotated upside down with the in-cell remotely operated equipment, so that the fiber glass screen is upward. The lid of the leach basket is then opened for media sampling. 


\subsection{LEACHING OF NWCF SPENT FILTERS}

This section describes the nitric acid leaching trials of six NWCF spent filters using the existing filter leaching facility and employing the leaching process parameters described in the section 3.0. The details of the six pre-leached NWCF filters are described in Appendix A, Table A-4.

In the course of the trials, it was observed that the average time of filter transportation from the PaR parking area to the filter handling cell was approximately 45 minutes. Breaching time was approximately 15 minutes. During filter breaching, the sharp spikes of the breaching tool did not fully penetrate inside the filter media as designed. Additional forces by the PaR were necessary for full penetration of the sharp spike into the filter media.

Prior to the start up of the leaching trials, VES-NCD-123 was flushed with 2000 gallons of water to clean out as many contaminants as possible. RCRA samples from the heel of VES-NCD-123 were collected and sent to the RAL via the PTS to analyze for TC Metals, Hg, VOC/SVOC, TRU, and acidity.

The molarity of the nitric acid used in the leaching trials is presented in Table 2 below:

Table 2. Nitric acid molarity for filter leach.

\begin{tabular}{|c|c|}
\hline Fitter ID & Molarity \\
\hline NWT-1 & 1.5 \\
\hline NWT-2 & 1.38 \\
\hline NWT-3 & 1.5 \\
\hline NWT-4 & 1.6 \\
\hline NWT-5 & 2.0 \\
\hline NWT-6 & 1.75 \\
\hline
\end{tabular}

At the conclusion of the leaching and rinsing cycles, the leachate and rinsate was drained to VES-NCD-123. The filters were then dried for 12-18 hours inside the leach vesse1. Appendix A, Tables A-6 through A-11, fully describe the process parameters for each of the six filters. 
RCRA samples for the leachate and rinsate were taken remotely from VES-NCD-123 through SAM-NCC-620 and sent to the RAL via the PTS. It is to be noted that a total of 517 liquid sample bottles of $15 \mathrm{ml}-\mathrm{glass}$ were sent to the RAL for analysis for this entire test.

Post-leach filter media was too loose and brittle for core sampling. (See Appendix A, Table A-5.) Samples were placed in two 8 oz glass bottles using the master-slave manipulators. The average radiation level in the sample bottles for all six filters was below $100 \mathrm{mr} / \mathrm{hr}-(\beta / \gamma)$. The sample bottles, along with trip blanks, were transported by hand to the RAL for RCRA analysis of TC Metals, Hg, acidity, Gamma scan, TRU, VOC, and SVOC.

At the conclusion of the trials, two leached filters, along with the leach basket, were placed within a wooden box which measured 6.1 inches $\times 31.5$ inches $x 16.5$ inches inside the decon cell. Two of the wooden boxes were sized to fit inside a standard waste box ( $4 \mathrm{ft} \times 4 \mathrm{ft} \times 8 \mathrm{ft}$ ) for removal to waste staging building CPP-1617 prior to transport to RWMC.

\subsection{Leaching of Filter \#1}

The filter was transported from the PaR parking area to the filter handling ce11 and positioned inside the leach basket. The maximum radiation level was measured to be $19.6 \mathrm{R} / \mathrm{hr}(\gamma)$. The condition of the filter media along with the housing appeared to be normal. Calcine particles were noticed on the fiber glass screen side of the filter. After breaching, the filter, along with the leach basket, was placed inside leach vessel VES-NCD-155 for leaching. After completion of leaching, the rinsate (2nd cycle) was sampled from VES-NCD-155. Average acid heatup time in VES-NCD-155 was 58 minutes. Both leach cycles were completed without any difficulties. The air sparge rate was 12-30 scfm. During the acid heatup for the third cycle, the low pressure steam valve (LS-155-1) handle was broken. After the handle had been repaired, all remaining leach and rinse cycles were completed. The average leachate/rinsate drain time from VES-NCD-155 to VES-NCD-123 was approximately 36 minutes. The rinsate sample (2nd cycle) radiation level was $4 \mathrm{mR} / \mathrm{hr}(\beta / \gamma)$ and was hand-carried to the RAL under RCT escort. RCRA samples from VES-NCD-123 were sent to the RAL via the PTS. 
The leached filter was dried inside the leach vessel for 16 hours. After the completion of the drying cycle, the leach basket was pulled out from the leach vessel and placed over the filter handling table. The basket was rotated upside down so that the fiber glass screen side was in the upward position and the basket lid was open. The filter media and fiber glass screen were intact. The filter media was brittle and loose. The sample tool was unable to collect a cored sample due to the brittle condition of the filter media. The filter media samples were collected by grab sampling in random locations and packed inside two $8 \mathrm{oz}$ glass bottles (>20 gm each bottle) using the master-slave manipulator. The radiation level of the media sample bottles was $50 \mathrm{mR} / \mathrm{hr}(\beta / \gamma)$. The sample bottles and trip blank $(>30 \mathrm{gm})$ were hand-carried to the RAL under RCT escort.

\subsection{Leaching of Filter \#2}

The second filter was transferred to the filter handling cell from the PaR parking area. The filter condition was not good. The filter media was disintegrated and the filter housing was separated from the filter media. The fiber glass screen was found torn. The radiation level was measured to be $5 \mathrm{R} / \mathrm{hr}(\gamma)$. The filter media was breached and $\mathrm{placed}$ inside VES-NCD-155 for leaching.

After the completion of the first leach cycle, the leachate could not be drained from leach vessel VES-NCD-155 to VES-NCD-123 due to plugging of the drain line by the disintegrated filter pulp which came out of the leach basket. A temporary blow back 1 ine was connected to the drain line and the plugged drain line was cleared using low pressure nitrogen gas. A11 leach and rinse cycles were completed without any problems. The average nitric acid heatup time was 44 minutes and the vessel drain time following the leach/rinse cycle was 46 minutes (excluding leach \#1 drain time). During leaching and rinsing, disintegration of the filter media occurred, which probably resulted due to the poor condition of the filter media. Some of the filter media came out of the leach basket in slurry form. The radiation level in the second rinsate sample was $5 \mathrm{mR} / \mathrm{hr}(\beta / \gamma)$. It was hand-carried to the RAL under RCT escort. RCRA samples for the leachate and rinsate were collected and sent to the RAL via the PTS. The filter was dried in the leach vessel for 16 hours. The leach basket was pulled out from the leach vessel and placed upside down on the filter handling table. 
The lid of the basket was opened for media sampling. Severe disintegration of the media samples was evident. Most of the disintegrated filter media (99\%) stayed inside the leach basket. Media samples were taken in two 8 oz glass bottles $(60 \mathrm{mR} / \mathrm{hr}(\beta / \gamma)$ and hand-carried to the RAL under RCT escort.

\subsection{Leaching of Filter \#3}

This spent filter was used in the last campaign (H3) of NWCF. The pre-leach radiation level was $85 \mathrm{R} / \mathrm{hr}(\gamma)$ and it was in very good condition. The filter was transported to the filter handling cell from the PaR parking area for leaching. The acid heatup rate was 39 minutes. The average vessel drain time was 29 minutes. The filter was breached and leached without any problems. The radiation level for the second rinse sample was $5 \mathrm{mR} / \mathrm{hr}(\beta / \gamma)$. The filter was dried for 16 hours. The media sample $35 \mathrm{mR} / \mathrm{hr}(\beta / \gamma)$ was collected and handcarried to the RAL along with the media trip blank and rinsate sample under RCT escort. The RCRA samples for the leachate and rinsate were collected from VES-NCD-123 and sent to the RAL via the PTS.

\subsection{Leaching of Filter \#4}

This spent filter was also used in the last campaign (H3) of NWCF. It was received in very good condition with a radiation level at $90 \mathrm{R} / \mathrm{hr}(\gamma)$. The filter was breached and leached without any problems. The average acid heatup time for each leach cycle was 36 minutes. The average vessel drain time was 29 minutes. The filter was dried for 18 hours. The leach basket was opened for media sampling. It was noticed that the stainless steel screen of the basket was separated from the basket frame on which the screen was riveted. Also, the latch of the basket lock was dissolved during leaching. It was observed that the rivets in the leach baskets were mistakenly made of aluminum alloys. Leach baskets \#5 and \#6 were reworked to replace aluminum rivets with stainless steel materials. After collecting media samples in glass bottles, the filter was put inside a wooden waste box ( $p$ laced in the cel1) with the help of the filter handling tool.

The radiation level of the filter media sample was $30 \mathrm{mR} / \mathrm{hr}(\beta / \gamma)$ and that of the second rinsate sample was below $5 \mathrm{mR} / \mathrm{hr}(\beta / \gamma)$. All samples were 
hand-carried to the RAL under RCT escort. The RCRA samples for leachate/rinsate were pulled from VES-NCC-123 remotely and sent to the RAL via the PTS.

\subsection{Leaching of Filter $\# 5$}

This filter was received in good condition from the PaR parking area. It also was used in the last (H3) NWCF campaign. The maximum radiation level was $120 \mathrm{R} / \mathrm{hr}(\gamma)$ in pre-leach condition. The filter was leached with the stainless steel screen side down. The average acid heatup time was 48 minutes for each leach cycle. During vessel draining for both second and third leach cycles, drainline strainer plugging was experienced and it resulted in a longer drain time of 62 minutes for the second leach and 40 minutes for the third leach cycle. The average vessel drain time was 41 minutes. The filter was dried for 16 hours in the leach vesse1. After drying, the leach basket was pulled out and placed over the filter handling table. The lid of the basket was opened for sampling. It was observed that the fiber glass screen was completely destroyed. Severe disintegration of the filter media had also occurred. The filter media was collapsed; especially in the mid-section of the filter. It is to be noted that this filter was leached with the stainless steel screen side down. During leaching, coupled with air sparging, the fiber glass screen at the top of the HEPA filter could not sustain the hydrodynamic pressure of the leaching solution, which resulted in the failure of the fiber glass screen of the filter. Some of the filter media (2\%) was dispersed into the leach/rinse solution as a slurry mass and plugged the vessel drain strainer during the second and third leach cycle. The media samples were taken in two glass bottles $80 \mathrm{mR} / \mathrm{hr}(\beta / \gamma)$ and handcarried to the RAL under RCT escort with the second rinsate sample $5 \mathrm{mR} / \mathrm{hr}(\beta / \gamma)$. The RCRA samples for leachate and rinsate were collected from VES-NCD-123 and sent to the RAL via the PTS.

\subsection{Leaching of Filter \#6}

The maximum radiation level of this filter was measured to be $18 \mathrm{R} / \mathrm{hr}(\gamma)$ in pre-leach condition. The filter condition was good and it was breached and leached without any problem. The average acid heatup time was 38 minutes for each leach cycle. The average vessel drain time was 42 minutes. The filter was dried for 16 hours. It was noticed that the latch of the basketlock dissolved completely. Media samples $90 \mathrm{mR} / \mathrm{hr}(\beta / \gamma)$ were collected and hand-carried to the 
RAL along with the second rinse sample $<5 \mathrm{mR} / \mathrm{hr}(\beta / \gamma)$ under $\mathrm{RCT}$ escort. RCRA samples for leachate and rinsate were collected from VES-NCD-123 and sent to the RAL via the PTS.

\subsection{RESULTS}

The six NWCF spent HEPA filters were successfully leached in the existing leach facility. During the leaching process, some operational problems were experienced which are not insurmountable. These problems will be corrected during the modification of the existing leaching system which is expected to commence in early 1995.

Post-leach media sample analysis results were below regulatory levels for the toxic characteristics (40 CFR 261.24). The TRU and non-TRU radiological characteristics of the leached filter media sample met RWMC disposal criteria for low-level radioactive waste. The volatile/semi-volatile organic constituents were analyzed but the results of the analysis were not accepted due to the expiration of holding times per regulatory requirements. All six filters were resampled for volatile and semi-volatile organic compounds analysis. The results of the analysis showed that the extent of contamination by those organics was extremely small and the HEPA filters can be disposed of as 10 - 1 evel radioactive waste. The results of the testing are being submitted to the State of Idaho for a regulatory determination which is made possible pursuant to a regulatory provision to exclude low-hazard debris from RCRA requirements [40 CFR 261.3(f)(2)]. After treatment in the HFLS, the leachate and rinsate will be considered hazardous waste and will be sampled for characterization purposes. Detailed chemical analysis of the media samples and composite samples of leachate and rinsates for all six filters is presented in Appendix A, Tables A-16 through A-25.

Two leached filters along with the leach baskets were $\mathrm{placed}$ in a wooden waste box. Two of the wooden waste boxes containing filters $\# 1,2,3$, and 4 were placed in a standard waste box. The radiological level $(\beta / \gamma)$ was measured to be $120 \mathrm{mR}$ at contact and $10 \mathrm{mR}$ at a 3 foot distance. The other standard waste box contained only one wooden box (filters $\# 5$ and 6 along with the leach baskets) and the radiation level $(\beta / \gamma)$ was reported to be $50 \mathrm{mR}$ at contact and $15 \mathrm{mR}$ at a 
3 foot distance. Both standard wooden waste boxes containing the leached filters met RWMC disposal criteria for shipment.

\subsection{DISCUSSION}

A11 six HEPA filters were leached under similar conditions except filter \#5 which was leached upside down with the fiber glass screen side up. The pre-leach and post-leach filter conditions are described in Appendix A, Tables A-4 and A-5. Post-leach media sample analyses revealed that all six filters treated in the HFLS were below regulatory levels for the toxic characteristic. (See Table 1).

TRU and non-TRU radiological analysis showed that the leached filters met INEL low-level radioactive waste acceptance criteria (DOE/ID-10112, Rev. 5). The volatile organics were analyzed per 57FR37230, August 18, 1993. All media sample analyses will be submitted to the State of Idaho. Filter leach test results have shown that the extent of organic contamination is extremely small and will conform to "debris treatment" so that the leached filters can be disposed as low-level non-hazardous waste (40 CFR 268). A11 chemical and radiological analysis is presented in Appendix A, Tables A-16 through A-25.

During leaching and rinsing of the filters, it was evidenced that small disintegrated filter particles in pulp form were coming out of the leach basket. The phenomenon was observed to the greatest extent during the leaching of filters \#2 and \#5. Filter \#2 was received in a disintegrated form and filter media was separated from the stainless steel housing. During the leaching of this filter, the VES-NCD-155 drainline became clogged by escaping filter pulp from the leach basket after the first leach cycle. The clogged drainline was cleared by connecting a temporary air blow down line in the drainline. Filter \#5 was leached in the upside down (fiber glass screen side up) position. Test results showed that leaching efficiency was as good as that of the other filters. It appeared that filter orientation did not have any affect on leaching efficiency. However, destruction of the fiber glass screen and severe filter media disintegration were evidenced during the leaching of filter \#5. The fiber glass screen could not sustain the air sparged liquid pressure during the leaching/rinsing cycles and tore apart. Most (98\%) of the disintegrated filter media was contained in the leach basket. Some of the filter pulp came out of the 
leach basket and clogged the leach vessel drain strainer resulting in longer vessel drain time.

During filter leach operations \#1 through \#6, filter particulates in the form of pulp were evidenced during the leaching and rinsing cycles and they came out of the leach basket. The use of smaller screen mesh in the leach basket may not be a viable solution to preclude escaping of filter pieces out of the leach basket. The filter pieces may clog the leach basket screen and affect leaching efficiency. It is suggested to install a permanent blow back system in the vessel drainline of the modified leaching system to clean the clogged drainline. During leaching of filter \#4, the latch in the locking mechanism of the basket was completely dissolved. The stainless steel screen mesh became separated from the basket frame due to the dissolution of the aluminum rivets by the nitric acid. During leaching of filter \#6, the latch of the basket locking mechanism was also dissolved which probably resulted from incompatible materials.

In the modified leaching system design, there is no provision for a blow down mechanism in the leach vessel drainline. Moreover, the drainline is designed in such a manner that post-leach disintegrated solid filter media will be drained out along with the leachate and rinsate to VES-NCD-123. This is unacceptable; therefore, incorporation of a permanent blow back mechanism in the vessel drainline and redesign of the vessel drain system are essential to preclude clogging of the leach vessel drainline and also to avoid the transfer of disintegrated filter media into VES-NCD-123.

The waste volume produced in the filter leaching trials is shown in Appendix A, Table A-12. The waste volume of leachate and rinsate generated during the leaching of each filter was 678 gallons in the existing filter leach system. As mentioned in section 3.0, the piping occupies the bottom 8 inches of the existing leaching vessel. Therefore, the existing leaching system is generating 45 gallons of unnecessary waste per leach/rinse cycle. As a result, 225 gallons of liquid waste generation will be minimized per filter leached in the modified leaching system (see section 8 ).

The leachate and rinsate waste generated during the course of the leaching trials was transferred to the PEW evaporator except during filter \#2 leach, where the liquid waste was transferred to VES-NCC-119 due to high chloride content. 
That process waste was sent to the PEW evaporator after being combined with a lower chloride waste solution in VES-NCC-119. The composite sample analysis of leachate and rinsate is shown in Appendix A, Table A-13.

The process analysis results of the leachate and rinsate for filters \#1, 3, 4, and 6 met the PEW evaporator acceptance criteria for disposal. The leachate and rinsate analysis of filters \#2 and \#5 showed higher chloride content which did not conform to the PEW evaporator acceptance criteria. The other constituents $\left(\mathrm{Fl}^{-}, \mathrm{SO}_{4}^{--}\right.$, and $\mathrm{Hg}^{++}$) in the leachate and rinsate solution of all six filters were well below the PEW evaporator acceptance limit. It is suggested that the leachate and rinsate solution be mixed with another similar waste prior to disposal to the PEW evaporator to minimize chloride content. It had been expected that the leachate and rinsate waste solution would go to the tank farm, but it was transferred to the PEW evaporator which resulted in a substantial savings in tank farm volume.

Assuming the composite samples of the leachate and rinsate will meet PEW acceptance criteria, a total of 453 gallons of waste volume would be produced per filter leach in the modified filter leach system and transferred to the PEW evaporator. Due to lower molarity of the acid solution used in the filter leaching operation, a 30.1 reduction ratio in the PEW evaporator is assumed. Thus, 15 gallons of waste solution from the PEW evaporator bottom will go to the tank farm per filter leach under the modified filter leach system.

The average leaching time in the existing process included filter handling from the PaR parking area, breaching, leaching, and rinsing activities. It is estimated that 10 hours total leaching time will be required to leach a spent NWCF filter without anticipating any delays. Appendix A, Table A-14 presents a comprehensive breakdown of filter handling and leaching time requirements.

\subsection{MODIFICATION OF PRESENT SYSTEM}

The majority of facility modifications are within the filter handling cell and would not require additional penetrations in the wall between the filter handling cell and the clean operating corridor. Figure 6 shows a sketch of the proposed modifications which include removal of the existing leaching vessel; replacement with a new leaching vessel; modifications to the filter handing 


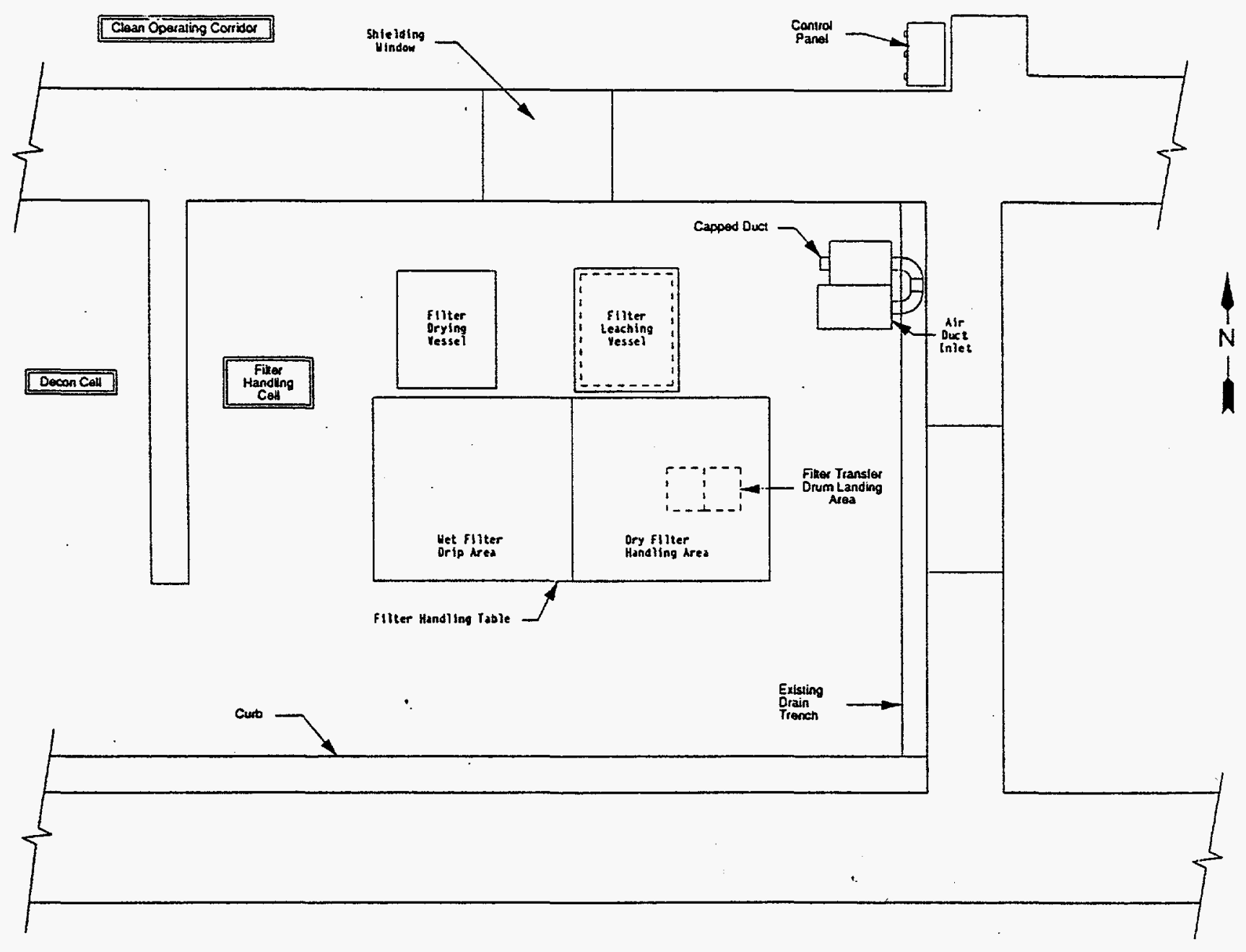

Figure 6. Modified filter leaching system plan view. 
table so that rinsed filters can be partially drip dried; removal of the existing sampling station and filter basket table; and installation of a separate filter drying vessel.

The existing leaching vessel has performed all functions required for filter leaching, but there are mitigating factors which support a replacement. The existing vessel produces 45 gallons of unnecessary liquid waste per filter leach because eight inches of the leaching vessel bottom is occupied by piping. In addition, the height of the existing leaching vessel obstructs the operator's view of almost half of the filter handling table which adversely affects the operability of the system. Finally, the leaching vessel is designed to accommodate filters up to 24 inches $\times 24$ inches $\times 12$ inches high. There are at least ten filters at the ICPP which measure 30 inches $\times 24$ inches $\times 12$ inches, and more of the same size at SPERT. The existing vessel cannot be used for the leaching of those filters. The new filter leaching vessel is designed to leach all filters sizes (one filter at a time for large filters, and four filters at a time for small filters). The total number of spent HEPA filters stored at the ICPP is presented in Table 3 below:

Table 3. Number of spent HEPA filters currently at the ICPP.

\begin{tabular}{|l|c|c|c|}
\hline \multicolumn{1}{|c|}{ Source } & $\begin{array}{c}\text { Radiation } \\
\text { Level }\end{array}$ & Inventory & $\begin{array}{c}\text { Filter } \\
\text { Dimensions }\end{array}$ \\
\hline $\begin{array}{l}\text { Fluorinel Dissolution Process } \\
\text { (FDP) }\end{array}$ & $\begin{array}{l}20-30 \mathrm{R} \\
20-30 \mathrm{R}\end{array}$ & $\begin{array}{c}129(\mathrm{DOG})^{\prime} \\
2-4(\mathrm{COG})^{2}\end{array}$ & $\begin{array}{l}8^{\prime \prime} \times 8^{\prime \prime} \times 6^{\prime \prime} \\
8^{\prime \prime} \times 8^{\prime \prime} \times 6^{\prime \prime}\end{array}$ \\
\hline $\begin{array}{l}\text { New Waste Calcining Facility } \\
\text { (NWCF) }\end{array}$ & $>50 \mathrm{R}$ & 113 & $2^{\prime} \times 2^{\prime} \times 1^{\prime \prime}$ \\
\hline $\begin{array}{l}\text { Radioactive Waste Management } \\
\text { Complex (RWMC) }\end{array}$ & $>50 \mathrm{R}$ & 34 & $2^{\prime} \times 2^{\prime} \times 1^{\prime \prime}$ \\
\hline $\begin{array}{l}\text { Atmospheric Protection } \\
\text { SystemNessel Off-Gas } \\
\text { (APSNOG) }\end{array}$ & $>10 \mathrm{R}$ & 9 & $2^{\prime} \times 2^{\prime} \times 1^{\prime}$ \\
\hline $\begin{array}{l}\text { Atmospheric Protection } \\
\text { System/Cell Off-Gas (APS/COG) }\end{array}$ & $>5 \mathrm{R}$ & 100 & $2^{\prime} \times 2^{\prime} \times 1^{\prime \prime}$ \\
\hline Waste Calcining Facility (WCF) & $>25 \mathrm{R}$ & $10-12$ & $28^{\prime \prime} \times 24^{\prime \prime} \times 8^{\prime \prime}$ \\
\hline $\begin{array}{l}1 \text { Dissolver Off-Gas } \\
\text { Cell Off-Gas }\end{array}$ & & & \\
\hline
\end{tabular}


The modified leaching system is designed to minimize the volume of leaching and rinsing solution requirements by el iminating much of the wasted volume at the bottom of the leach vessel. Stainless steel filler blocks could also be used to displace volume when leaching all but the largest filters. The modified leaching vessel would be shorter than the existing vessel by approximately one foot which would provide better operator visibility of the leach vessel interior and the filter handling table. A schematic of the modified leaching system is shown in Figure 7.

The proposed leaching system modification does not include a vessel blow down mechanism and the vessel drainline goes directly to the cell drain trench. The present validation test of the six NWCF HEPA filters experienced both vessel drainline and strainer plugging by filter media. This phenomena suggests that a permanent blow down mechanism in the vessel drainline, coupled with a drain pan with strainer (like the existing system), should be considered to prevent drainline clogging and transfer of disintegrated filter media to VES-NCD-123.

\subsection{FILTER THROUGHPUT}

Several factors will significantly affect the HEPA filter leaching throughput rate including drying time, manpower availability, sampling requirements, sample analysis turnaround, equipment failure rate, and releaching of filters. It is difficult to quantify the filter throughput for the HEPA filter leaching system. The following approach makes a reasonable estimate of filter throughput. A batch of four large filters (or sixteen small filters) could be processed in a batch mode through the modified leaching system in five working days with two shifts in operation. (See Appendix A, Table A-15.) Time estimates for each step are based on the experience obtained in the leaching test. (See Appendix A, Table A-14.) It is assumed all four filters would be leached without any interruptions and all leachate and rinsate would be transferred to VES-NCD-123. The estimated volume of leachate and rinsate would be 1812 gallons which could then be sampled for disposal. The waste volume might need to be added to another waste stream to lower the chloride content to meet the PEW evaporator acceptance criteria.

A processing rate of four filters per week would equate to a monthly throughput rate of seventeen large filters per month. The above monthly 


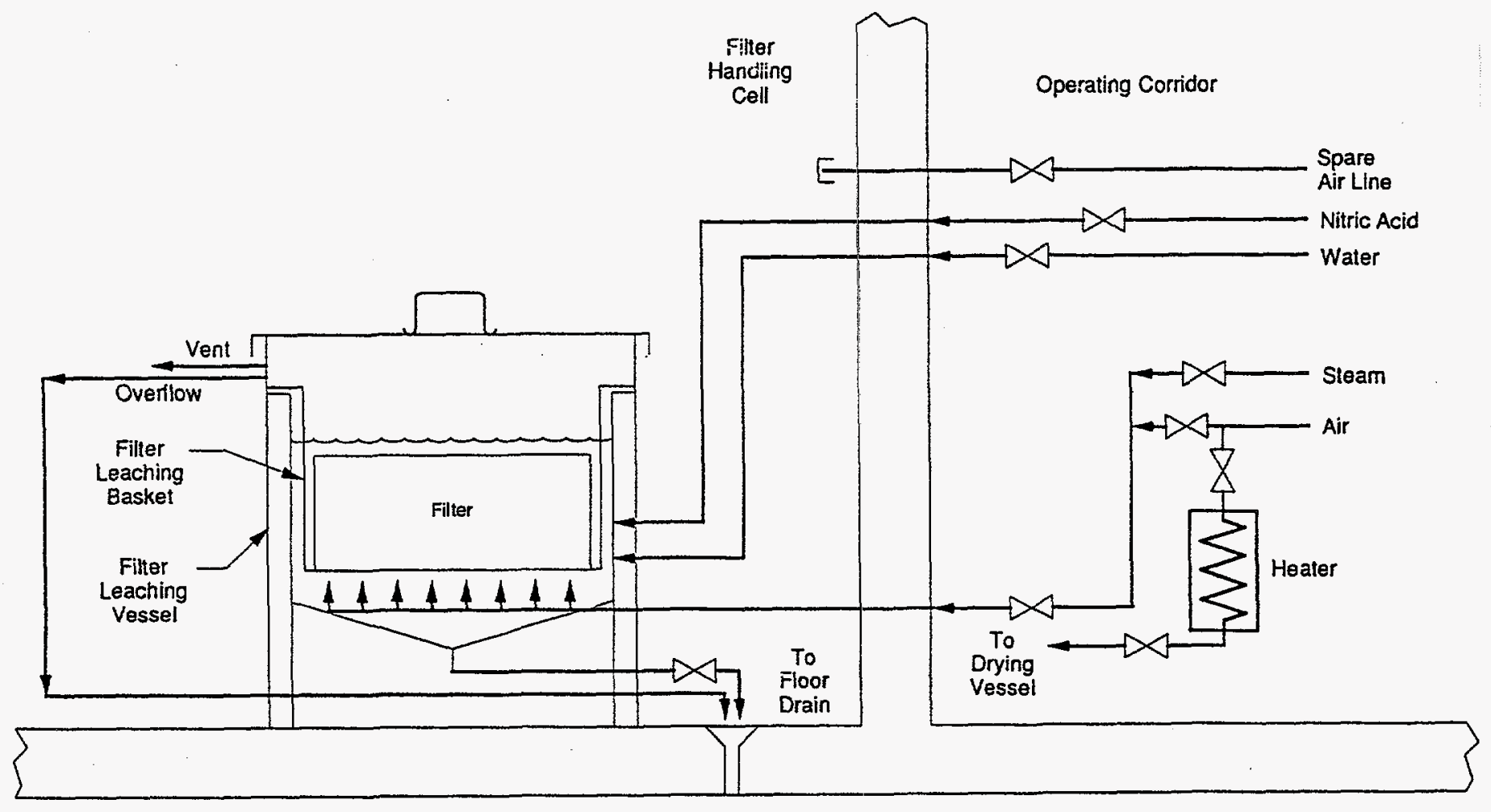

Figure 7. Modified filter leaching system flow chart. 
throughput value assumes ful1-time operation of the system and does not consider lost time to equipment breakdown, repair, or other related constraints. Considering equipment downtime and intermittent operation of the leach system (50\% downtime) it is estimated eight large filters could be leached per month.

\subsection{CONCLUSIONS}

After completion of leaching of all the six hot filters, the following results were derived:

- $\quad$ Six NWCF HEPA filters were leached successfully without any major problems using the existing leaching system.

- Most ( $>98 \%)$ of the loose post-leach filter media stayed inside the leach basket.

- During leaching, disintegrated filter media in the form of "pulp" was evidenced in the leaching solution. It had escaped from the leach basket and plugged the vessel drainline during the leaching of filters \#2 and \#5.

- Media sample analysis revealed that the filter leach concept (with modified process parameters) met both RCRA and radiological criteria for disposal as low-level waste.

- Filter orientation does not have any affect on leaching to remove hazardous and radiological particulates; however, severe media disintegration was evidenced due to the destruction of the fiber glass screen of the HEPA filters.

- The breaching tool did not perform effectively.

\subsection{RECOMMENDATIONS}

Leaching activities of the six hot filters determined that the following steps should be taken for the success of the HEPA filter leaching process: 
- Installation of a blow down mechanism and a drain pan with strainer is highly recommended to minimize restricted drainlines and undissolved solids (filter media) in VES-NCD-123.

- The material compatibility of the latch in the locking system of the leaching basket must be ensured.

- It is desirable to collect post-leach media samples employing batch sampling techniques because core sampling is impractical.

- The filter should be leached stainless steel screen side up to prevent severe filter media disintegration.

- The need for breaching filters should be evaluated.

- The breaching tool should be redesigned and rebuilt for easy penetration inside the filter media during mechanical breaching.

- A sampling station outside the leach vessel should be added.

\subsection{REFERENCES}

1. G. W. Hogg Letter (HOGG-23-92) to L. F. Ermold, "HEPA Filter Leach Technical Bases and Operating Recommendation"

2. Thornton H. Waite, Design and Installation of a Radioactive Filter Leaching System at the Idaho Chemical Processing Plant. Proceedings, 36th Conference on Remote System Technology, 1988, Volume 2. 


\section{ApPendiX A}

Filter leach Trials Data

A-1 

Table 4. Pre-leach filter condition.

\begin{tabular}{|c|c|c|c|c|c|c|}
\hline Filter No. & Filter ID & $\begin{array}{c}\text { Medla } \\
\text { Condition }\end{array}$ & $\begin{array}{l}\text { Housing } \\
\text { Condition }\end{array}$ & $\begin{array}{l}\text { Screens } \\
\text { Condition }\end{array}$ & $\begin{array}{l}\text { Maximum } \\
\text { Radiation } \\
\text { Level }(\gamma) \\
\end{array}$ & Remarks \\
\hline NWT - 1 & Not avallable & Good & Good & Good & $20 \mathrm{R} / \mathrm{hr}$ & $\begin{array}{l}\text { Large particles of calcine noticed } \\
\text { (blue tint color) }\end{array}$ \\
\hline NWT - 2 & Not avaflable & Fair & Warped & $\begin{array}{l}\text { Fiberglass } \\
\text { screen } \\
\text { damaged }\end{array}$ & $5 \mathrm{R} / \mathrm{hr}$ & $\begin{array}{l}\text { No evidence of calcine material } \\
\text { over the filter media }\end{array}$ \\
\hline NWT - 3 & $\begin{array}{l}8-27-93 \\
\# 2 \text { pre-filter }\end{array}$ & Good & Good & Good & $85 \mathrm{R} / \mathrm{hr}$ & $\begin{array}{l}\text { Large particles of calcine not tced } \\
\text { (blue tint color) }\end{array}$ \\
\hline NWT -4 & $\begin{array}{l}8-27-93 \\
\# 2 \text { middle } \\
\text { filter } \\
\end{array}$ & Good & Good & Good & $90 \mathrm{R} / \mathrm{hr}$ & $\begin{array}{l}\text { No evidence of calcine material } \\
\text { over the filter media }\end{array}$ \\
\hline NWT - 5 & $\begin{array}{l}5-27-93 \\
\# 4 \text { pre-filter }\end{array}$ & Good & Good & Good & $120 \mathrm{R} / \mathrm{hr}$ & $\begin{array}{l}\text { No evidence of calcine material } \\
\text { over the filter media. }\end{array}$ \\
\hline NWT - 6 & $\begin{array}{l}7-15-93 \\
\$ 3 \text { middle } \\
\text { filter } \\
\end{array}$ & Good & Good & Good & $18 \mathrm{R} / \mathrm{hr}$ & $\begin{array}{l}\text { No evidence of calcine material } \\
\text { over the filter media. }\end{array}$ \\
\hline
\end{tabular}

Filters \#3 and \#4 were in-service from 8-27-93 to 9-15-93.

Filter \#5 was in-service from 5-27-93 to 6-27-93.

Filter \#6 was in-service from 7-15-93 to 8-21-93. 
Table 5. Post-leach filter drying parameters, filter media conditions and sampling.

\begin{tabular}{|c|c|c|c|c|c|c|c|}
\hline & Filter \#1 & Filter \#2 & Filter $\# 3$ & Filter \#4 & Ftlter $\# 5$ & F11ter $\# 6$ & Remarks \\
\hline Filter 10 & NWT- 1 & NWT-2 & NWT-3 & NWT-4 & NWT -5 & NHT-6 & $\begin{array}{l}\text { Grab samples were taken } \\
\text { on all fllters due to } \\
\text { media deterloration. }\end{array}$ \\
\hline $\begin{array}{l}\text { Drying Air } \\
\text { Temp ('F) }\end{array}$ & 420 & 420 & 420 & 420 & 420 & 420 & \\
\hline $\begin{array}{l}\text { Air Flow Rate } \\
(\mathrm{scfm})\end{array}$ & 50 & 50 & 50 & 50 & 50 & 50 & \\
\hline $\begin{array}{l}\text { Drying Time } \\
\text { (hrs) }\end{array}$ & 16 & 17 & 13 & 12 & 12 & 12 & \\
\hline $\begin{array}{l}\text { Media } \\
\text { Condition }\end{array}$ & $\begin{array}{l}\text { Loose and } \\
\text { brittle }\end{array}$ & $\begin{array}{l}\text { Loose and } \\
\text { extremely } \\
\text { brittle } \\
\text { (10\% of } \\
\text { loose } \\
\text { filter in } \\
\text { the basket) }\end{array}$ & $\begin{array}{l}\text { Loose and } \\
\text { brittle }\end{array}$ & $\begin{array}{l}\text { Loose and } \\
\text { brittle }\end{array}$ & $\begin{array}{l}\text { Media blown } \\
\text { apart. } \\
\text { Extremely } \\
\text { loose and } \\
\text { brittle }\end{array}$ & $\begin{array}{l}\text { Loose and } \\
\text { brittle }\end{array}$ & $\begin{array}{l}\text { Most of the loose media } \\
\text { was contained in the } \\
\text { basket. }\end{array}$ \\
\hline $\begin{array}{l}\text { Location of } \\
\text { Samples }\end{array}$ & Random & Random & Random & Random & Random & Random & \\
\hline $\begin{array}{l}\text { Weight of the } \\
\text { Sample }\end{array}$ & $>40 \mathrm{gm}$ & $>40 \mathrm{gm}$ & $>40 \mathrm{gm}$ & $>40 \mathrm{gm}$ & $>40 \mathrm{gm}$ & $>40 \mathrm{gm}$ & \\
\hline $\begin{array}{l}\text { Sample } \\
\text { Radiation } \\
\text { Level }(\beta / \gamma)\end{array}$ & $50 \mathrm{mR} / \mathrm{hr}$ & $60 \mathrm{mR} / \mathrm{hr}$ & $35 \mathrm{mR} / \mathrm{hr}$ & $B O \mathrm{mR} / \mathrm{hr}$ & $90 \mathrm{mR} / \mathrm{hr}$ & $90 \mathrm{mR} / \mathrm{hr}$ & \\
\hline $\begin{array}{l}\text { Weight of } \\
\text { trip blank }\end{array}$ & $>20 \mathrm{gm}$ & $>20 \mathrm{gm}$ & $>20 \mathrm{gm}$ & $>20 \mathrm{gm}$ & $>20 \mathrm{gm}$ & $>20 \mathrm{gm}$ & \\
\hline
\end{tabular}


Table 6. HEPA filter leach/rinse cycles (F1lter ID - NWT\#1).

\begin{tabular}{|c|c|c|c|c|c|c|}
\hline & Leach \#1 & Leach \#2 & Leach \#3 & Rinse \#1 & Rinse \#2 & Remarks \\
\hline $\begin{array}{l}\text { Approximate } \\
\text { Acid/Water Volume } \\
\text { in VES-NCD-155 } \\
\text { (gallons) } \\
\end{array}$ & 143 & 143 & 143 & 138 & 138 & \\
\hline $\begin{array}{l}\text { Acid heating time } \\
(\min )\end{array}$ & 45 & 50 & $80^{*}$ & & & $\begin{array}{l}\text { * Acid heating was stopped due to } \\
\text { breakage of LS-155-2 valve handle. } \\
\text { After the repair of the valve handle, } \\
\text { acid heating resumed. Acid heat up } \\
\text { time was longer because the acid in } \\
\text { the leach vessel had cooled down. }\end{array}$ \\
\hline $\begin{array}{l}\text { Acid Solution temp } \\
\text { of during leaching } \\
\end{array}$ & $182-188$ & $180-190$ & $186-190$ & & & \\
\hline Leaching time (min) & 40 & 40 & 40 & & & \\
\hline $\begin{array}{l}\text { Water temperature } \\
{ }^{\circ} \mathrm{F} \text { during rinsing } \\
\end{array}$ & & & & $85-89$ & $74-78$ & \\
\hline Rinse time (min) & & & & 15 & 15 & \\
\hline Sparge rate (scfm) & $12-30$ & $12-30$ & $12-30$ & $12-30$ & $12-30$ & \\
\hline $\begin{array}{l}\text { Vessel drain time } \\
\text { (min) }\end{array}$ & 49 & 37 & 32 & 25 & 38 & \\
\hline
\end{tabular}


Table 7. HEPA filter leach/rinse cycles (Filter ID - NWT\#2).

\begin{tabular}{|c|c|c|c|c|c|c|}
\hline & Leach \#1 & Leach \#2 & Leach \#3 & Rinse \#1 & Rinse \#2 & Remarks \\
\hline $\begin{array}{l}\text { Approximate } \\
\text { Acid/Water Volume in } \\
\text { VES-NCD-155 } \\
\text { (gallons) }\end{array}$ & 146.6 & 146.6 & 146.6 & 126.5 & 126.5 & \\
\hline $\begin{array}{l}\text { Acid heating time } \\
\text { (min) }\end{array}$ & 50 & 40 & 43 & & & \\
\hline $\begin{array}{l}\text { Acid Solution temp } \\
\text { - F during leaching } \\
\end{array}$ & $174-190$ & $170-190$ & $172-190$ & & & \\
\hline Leaching time (min) & 40 & 40 & 40 & & & \\
\hline $\begin{array}{l}\text { Water temp }{ }^{\circ} \mathrm{F} \text { during } \\
\text { rinsing }\end{array}$ & & & & 84 & $74-75$ & \\
\hline Rinse time (min) & & & & 15 & 15 & \\
\hline Sparge rate (scfm) & 12 & 12 & 12 & 12 & 12 & \\
\hline $\begin{array}{l}\text { Vessel drain time } \\
\text { (min) }\end{array}$ & $600^{*}$ & 50 & 43 & 42 & 47 & * Vessel drain line clogged. \\
\hline
\end{tabular}


Table 8. HEPA filter leach/rinse cycles (Fi1ter ID - NWT\#3).

\begin{tabular}{|c|c|c|c|c|c|c|}
\hline & Leach \#1 & Leach \#2 & Leach \#3 & Rinse \#1 & Rinse \#2 & Remarks \\
\hline $\begin{array}{l}\text { Approximate Acid/Water } \\
\text { Volume in VES-NCD-155 } \\
\text { (gallons) }\end{array}$ & 138 & 138 & 138 & 139 & 139 & \\
\hline $\begin{array}{l}\text { Acid heating time } \\
(\min )\end{array}$ & 45 & 34 & 37 & & & \\
\hline $\begin{array}{l}\text { Acid Solution temp }{ }^{\circ} \mathrm{F} \\
\text { during leaching }\end{array}$ & $167-191$ & $170-190$ & $168-191$ & & & \\
\hline Leaching time (min) & 40 & 40 & 40 & & & \\
\hline $\begin{array}{l}\text { Water temp } \cdot F \text { during } \\
\text { rinsing }\end{array}$ & & & & $82-90$ & $76-80$ & \\
\hline Rinse time (min) & & & & 15 & 15 & \\
\hline Sparge rate (scfm) & $12-30$ & $12-30$ & $12-30$ & $12-30$ & $12-30$ & \\
\hline $\begin{array}{l}\text { Vesse1 drain time } \\
\text { (min) }\end{array}$ & 26 & 30 & 30 & 32 & 27 & \\
\hline
\end{tabular}


Table 9. HEPA filter leach/rinse cycles (Filter ID - NWT\#4).

\begin{tabular}{|c|c|c|c|c|c|c|}
\hline & Leach \#1 & Leach \#2 & Leach \#3 & Rinse \#1 & Rinse \#2 & Remarks \\
\hline $\begin{array}{l}\text { Approximate } \\
\text { Acid/Water Volume in } \\
\text { VES-NCD-155 (gallons) }\end{array}$ & 133 & 133 & 133 & 118.5 & 118.5 & \\
\hline $\begin{array}{l}\text { Acid heating time } \\
(\min )\end{array}$ & 40 & 32 & 37 & & & \\
\hline $\begin{array}{l}\text { Acid Solution temp ' } F \\
\text { during leaching }\end{array}$ & $167-191$ & $170-191$ & $168-191$ & & & \\
\hline Leaching time (min) & 40 & 40 & 40 & & & \\
\hline $\begin{array}{l}\text { Water terip ' } \mathrm{F} \text { during } \\
\text { rinsing }\end{array}$ & & & & $82-90$ & $76-80$ & \\
\hline Rinse time (min) & & & & 15 & 15 & \\
\hline Sparge rate (scfm) & $12-30$ & $12-30$ & $12-30$ & $12-30$ & $12-30$ & \\
\hline $\begin{array}{l}\text { Vessel drain time } \\
\text { (min) }\end{array}$ & 26 & 30 & 30 & 32 & 27 & \\
\hline
\end{tabular}


Table 10. HEPA filter leach/rinse cycles (Filter ID - NWT\#5).

\begin{tabular}{|c|c|c|c|c|c|c|}
\hline & Leach \#1 & Leach \#2 & Leach \#3 & Rinse \#1 & Rinse \#2 & Remarks \\
\hline $\begin{array}{l}\text { Approximate } \\
\text { Acid/Water Volume in } \\
\text { VES-NCD-155 (gallons) }\end{array}$ & 138 & 138 & 138 & 139.5 & 139.5 & \\
\hline $\begin{array}{l}\text { Acid heating time } \\
\text { (min) }\end{array}$ & 40 & 66 & 40 & & & \\
\hline $\begin{array}{l}\text { Acid Solution temp }{ }^{\circ} \mathrm{F} \\
\text { during leaching }\end{array}$ & $174-191$ & $170-191$ & $169-191$ & & & \\
\hline Leaching time (min) & 40 & 40 & 40 & & & \\
\hline $\begin{array}{l}\text { Water temp of during } \\
\text { rinsing }\end{array}$ & & & & $91-94$ & $88-94$ & \\
\hline Rinse time (min) & & & & 15 & 15 & \\
\hline Sparge rate (scfm) & $12-30$ & $12-30$ & $12-30$ & 12 & 12 & \\
\hline $\begin{array}{l}\text { Vessel drain time } \\
\text { (min) }\end{array}$ & 37 & $62 *$ & $40 *$ & 35 & 30 & * Drain pan strainer got plugged. \\
\hline
\end{tabular}


Table 11. HEPA filter leach/rinse cycles (Filter ID - NHTH6).

\begin{tabular}{|c|c|c|c|c|c|c|}
\hline & Leach \#1 & Leach \#2 & Leach \#3 & Rinse \#1 & Rinse \#2 & Remarks \\
\hline $\begin{array}{l}\text { Approximate } \\
\text { Acid/Water Volume in } \\
\text { VES-NCD-155 (gallons) }\end{array}$ & 139 & 139 & 139 & 112.5 & 112.5 & \\
\hline $\begin{array}{l}\text { Acid heating time } \\
\text { (min) }\end{array}$ & 40 & 35 & 40 & & & \\
\hline $\begin{array}{l}\text { Acid Solution temp }{ }^{\circ} \mathrm{F} \\
\text { during leaching }\end{array}$ & $166-191$ & $172-191$ & $166-191$ & & & \\
\hline Leaching time (min) & 40 & 40 & 40 & & & \\
\hline $\begin{array}{l}\text { Water temp }{ }^{\circ} \mathrm{F} \text { during } \\
\text { rinsing }\end{array}$ & & & & $88-89$ & $76-77$ & \\
\hline Rinse time (min) & & & & 15 & 15 & \\
\hline Sparge rate (scfm) & $12-30$ & $12-30$ & $12-30$ & $12-30$ & $12-30$ & \\
\hline Vessel drain time & 45 & 42 & 45 & 40 & 36 & \\
\hline
\end{tabular}


Table 12. Acid/water volume consumed and waste volume generated during filter leach.

\begin{tabular}{|l|c|c|c|c|c|c|c|}
\hline \multicolumn{1}{|c|}{ Filter } & $\# 1$ & $\# 2$ & $\# 3$ & $\# 4$ & $\# 5$ & $\# 6$ & Average \\
\hline Acid Volume (gallons) & 430 & 440 & 414 & 400 & 414 & 419 & 419.5 \\
\hline Water Volume (gallons) & 276 & 253 & 279 & 237 & 279 & 225 & 258 \\
\hline Waste Volume (gallons) & 706 & 693 & 693 & 637 & 693 & 644 & 677.5 \\
\hline $\begin{array}{l}\text { Projected Acid Volume in } \\
\text { Modified System (gallons) }\end{array}$ & 295 & 305 & 279 & 265 & 279 & 284 & 284.5 \\
\hline $\begin{array}{l}\text { Projected Water Volume in } \\
\text { Modiffed System (gallons) }\end{array}$ & 186 & 163 & 189 & 147 & 189 & 135 & 168 \\
\hline $\begin{array}{l}\text { Projected Waste Volume } \\
\text { Generation in Modified System } \\
\text { gallons) }\end{array}$ & 481 & 468 & 468 & 412 & 468 & 419 & 452.6 \\
\hline
\end{tabular}


Table 13. Analysis of leachate and rinsate from VES-NCD-123.

\begin{tabular}{|c|c|c|c|c|c|c|c|}
\hline Constituents & $\begin{array}{c}\text { PEW Evaporator } \\
\text { Acceptance } \\
\text { Limit }\end{array}$ & Filter \#1 & Filter \#2 & Filter \#3 & Filter \#4 & Fi1ter \#5 & Filter \#6 \\
\hline $\mathrm{Cl}^{-}(\mathrm{ppm})$ & 50 & 40 & 195 & 30 & 30 & 144 & 33.1 \\
\hline $\mathrm{Fl}^{-}(\mathrm{ppm})$ & 200 & 25.6 & 25.64 & 25.6 & 70 & 79 & 25.6 \\
\hline $\mathrm{SO}_{4}^{--}(\mathrm{ppm})$ & 100 & 60 & 56.9 & 71.5 & 76.7 & 75.1 & 108 \\
\hline $\mathrm{Hg}^{+1}(\mathrm{ppm})$ & 80 & 4.64 & 5.09 & 4.38 & 2.98 & 7.79 & 3.73 \\
\hline $\begin{array}{c}\text { Undissolved Solids } \\
\text { (g/liter) }\end{array}$ & 50 & 6.6 & 1.43 & 2.6 & 3.28 & & \\
\hline
\end{tabular}

NOTE: After leaching filter \#6, leachate in VES-NCD-123 was diluted before transferring from VES-NCD-123 to the PEW evaporator. 
Table 14. Filter handling and leaching time.

\begin{tabular}{|c|c|}
\hline Activity & Time $(\min )$ \\
\hline $\begin{array}{l}\text { 1. Transfer filter from PaR parking } \\
\text { area to filter handling cell }\end{array}$ & 45 \\
\hline $\begin{array}{l}\text { 2. Position filter into the leach } \\
\text { basket }\end{array}$ & 10 \\
\hline 3. Breach filter & 15 \\
\hline $\begin{array}{l}\text { 4. Position the leach basket with } \\
\text { the filter inside the leach } \\
\text { vessel }\end{array}$ & 10 \\
\hline Total time for filter handling & 80 \\
\hline $\begin{array}{l}\text { 5. Acid transfer and heat up in } \\
\text { VES-NCD-155 }\end{array}$ & 45 \\
\hline 6. Leach cycle & 40 \\
\hline 7. Drain time & 40 \\
\hline Total leach time & $125 \times 3=375$ \\
\hline 8. Rinse time & 15 \\
\hline 9. Drain time & 40 \\
\hline Total rinse time & $55 \times 2=110$ \\
\hline
\end{tabular}

Total leach time $=80+375+110=565$ minutes (approx. 10 hours) 
Table 15. Activity schedule for batch throughput.

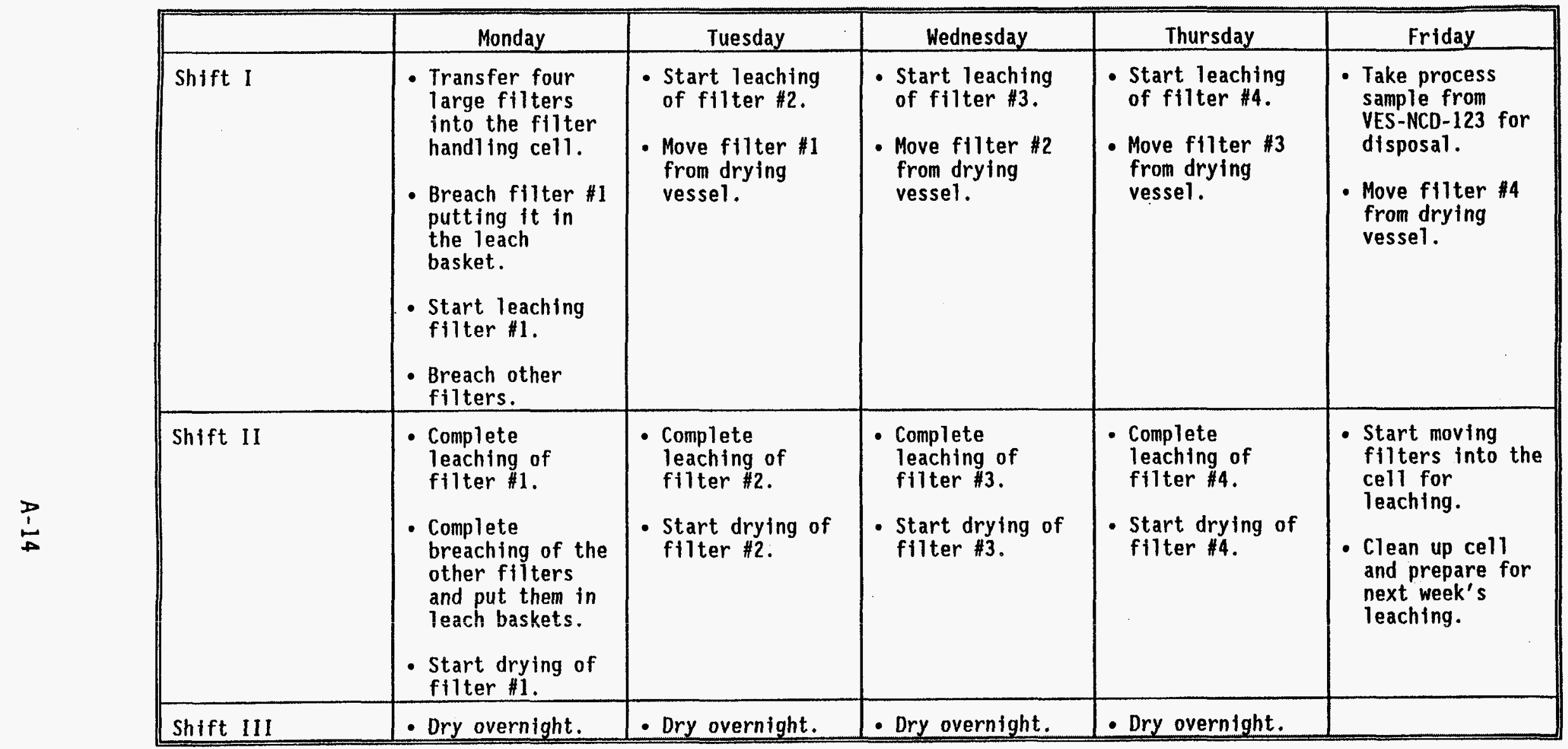


Table 16. TRU results on HEPA filter media.

\begin{tabular}{|c|c|c|}
\hline Filter & Log \# & $\begin{array}{c}\text { Gross Alpha } \\
\text { nCi } / \mathrm{g}\end{array}$ \\
\hline 1 & 022110 & 3.6 \\
\hline 2 & 022512 & 1.2 \\
\hline 3 & 030418 & 0.8 \\
\hline 4 & 031125 & 1.4 \\
\hline 5 & 03169 & 0.6 \\
\hline 6 & 032822 & 0.4 \\
\hline
\end{tabular}


Table 17. Six HFLS filter media samples analyzed for RCRA metals in 1994.

\begin{tabular}{|c|c|c|c|c|c|c|c||}
\hline Constituent & $\begin{array}{c}\text { Regulatory } \\
\text { Limit }\end{array}$ & $\begin{array}{c}\text { Filter \#1 } \\
94-022110 \\
(\mathrm{mg} / 1)\end{array}$ & $\begin{array}{c}\text { Filter \#2 } \\
94-022512 \\
(\mathrm{mg} / 1)\end{array}$ & $\begin{array}{c}\text { Filter \#3 } \\
94-030418 \\
(\mathrm{mg} / 1)\end{array}$ & $\begin{array}{c}\text { Filter \#4 } \\
94-031125 \\
(\mathrm{mg} / 1)\end{array}$ & $\begin{array}{c}\text { Filter \#5 } \\
94-03169 \\
(\mathrm{mg} / 1)\end{array}$ & $\begin{array}{c}\text { Fi1ter \#6 } \\
94-032822 \\
(\mathrm{mg} / 1)\end{array}$ \\
\hline Arsenic & $5 \mathrm{mg} / 1$ & $<0.170$ & $<0.681$ & $<0.671$ & $<0.170$ & $<0.170$ & $<0.170$ \\
\hline Barium & $100 \mathrm{mg} / 1$ & 0.240 & 3.62 & $<0.865$ & $<0.219$ & 0.48 & $<0.219$ \\
\hline Cadmium & $1 \mathrm{mg} / 1$ & $<0.216$ & $<0.866$ & $<0.853$ & $<0.216$ & $<0.216$ & $<0.216$ \\
\hline Chromium & $5 \mathrm{mg} / 1$ & $<0.208$ & $<0.833$ & $<0.820$ & $<0.208$ & $<0.208$ & $<0.208$ \\
\hline Lead & $5 \mathrm{mg} / 1$ & $<0.143$ & $<0.575$ & $<0.566$ & $<0.143$ & $<0.143$ & $<0.143$ \\
\hline Mercury & $0.2 \mathrm{mg} / 1$ & $<0.0402$ & $<0.0402$ & 0.018 & 0.016 & 0.092 & 0.012 \\
\hline Selenium & $1 \mathrm{mg} / 1$ & $<0.149$ & $<0.599$ & $<0.590$ & $<0.149$ & $<0.149$ & $<0.149$ \\
\hline Silver & $5 \mathrm{mg} / 1$ & $<0.194$ & $<0.777$ & $<0.765$ & $<0.194$ & $<0.194$ & $<0.194$ \\
\hline
\end{tabular}

This table provides the analytical results for each RCRA TC Metal analyzed for in the filter media samples. Detection limits will vary based on the size of the sample dilution.

These analyzes were performed at ICPP laboratories. 
Table 18. Six HFLS filter rinsate samples analyzed in 1994 for RCRA metals.

\begin{tabular}{|c|c|c|c|c|c|c|c|c|}
\hline Constltuent & $\begin{array}{l}\text { Regulatory } \\
\text { Limit }\end{array}$ & $\begin{array}{c}\text { Baseline } \\
\text { 94-012010 } \\
\text { ppm }\end{array}$ & $\begin{array}{c}\text { \#1 Ainse } \\
94-022012 \\
\text { ppm }\end{array}$ & $\begin{array}{c}\text { \#2 Ainse } \\
\text { 94-022512 } \\
\text { ppm }\end{array}$ & $\begin{array}{c}\text { \#3 Rinse } \\
94-030418 \\
\text { ppm }\end{array}$ & $\begin{array}{c}\text { \#4 Alinse } \\
\text { 94-0031125 } \\
\text { ppm }\end{array}$ & $\begin{array}{c}\text { \#5 Ainse } \\
94-03169 \\
\text { ppm }\end{array}$ & $\begin{array}{c}\text { \#6 Plinse } \\
94-032619 \\
\text { ppm }\end{array}$ \\
\hline Arsenic & 5 ppm & $<3.55$ & $<0.170$ & $<0.170$ & $<0.681$ & $<0.679$ & $<0.679$ & $<0.68$ \\
\hline Barium & 100 ppm & $<4.03$ & 0.33 & 2.25 & $<0.878$ & 1.56 & 2.34 & 1.19 \\
\hline Cadmium & $1 \mathrm{ppm}$ & $<0.539$ & 1.91 & 1.55 & $<0.865$ & 20.04 & 21.58 & 10.17 \\
\hline Chromlum & 5 ppm & $<4.09$ & 1.63 & 1.38 & 13.29 & 1.20 & 1.23 & 0.84 \\
\hline Lead & 5 ppm & $<4.39$ & 0.28 & 0.19 & $<0.575$ & $<0.573$ & $<0,573$ & $<0.575$ \\
\hline Mercury & $0.2 \mathrm{ppm}$ & $<0.001$ & 1.50 & 3.45 & 7.85 & 4.30 & 9.10 & 12.00 \\
\hline Nickel & 139 ppm & $<5.34$ & 0.78 & 0.75 & $<0.809$ & $<0.807$ & $<0.807$ & $<0.809$ \\
\hline Selenium & $1 \mathrm{ppm}$ & $<0.550$ & $<0.149$ & $<0.149$ & 2.07 & $<0.597$ & $<0.597$ & $<0.599$ \\
\hline Silver & $5 \mathrm{ppm}$ & $<1.56$ & $<0.194$ & $<0.777$ & 1.22 & $<0.775$ & $<0.777$ & $<0.777$ \\
\hline
\end{tabular}

This table provides the associated analytical results for each of the RCRA TC Metals analyzed for in the filter rinsate. Detection limits will vary based on the size of the sample dilution.

These analyzes were performed at ICPP laboratories.

In all tables, "rinse" means a composite sample of leachate and rinsate from vessel VES-NCD-123. 
Table 19. HFLS 1994 six filter media samples ran for total analysis by GC/MS.

\begin{tabular}{|c|c|c|c|c|c|c|c|c|}
\hline Constituent & CAS Numbor & Regulatory Limit & $\begin{array}{c}\text { Filter \#1 } \\
84-022110 \\
(\mathrm{ng} / \mathrm{mll}) \\
\end{array}$ & $\begin{array}{c}\text { Filter } 12 \\
94-022512 \\
{[\mathrm{ng} / \mathrm{ml})} \\
\end{array}$ & $\begin{array}{c}\text { Filtor } * 3 \\
94.030418 \\
\text { (ng/m) }\end{array}$ & $\begin{array}{c}\text { Filtor } 14 \\
94-031125 \\
\text { (no/mll } \\
\end{array}$ & $\begin{array}{c}\text { Fiftor } 15 \\
\text { 94.03169 } \\
\text { [nu/mll) }\end{array}$ & $\begin{array}{c}\text { Filter \#0 } \\
94.032822 \\
\text { [ng/mil) } \\
\end{array}$ \\
\hline Chloromothane & 74.87 .3 & $004533,000 \mathrm{ng} / \mathrm{ml}$ & $<52$ & $<50 \&<49$ & $<60$ & $<50$ & $<50 \&<46$ & $<50 \&<49$ \\
\hline Vinyl Chlorido & $76.01-4$ & $404333,000 \mathrm{ng} / \mathrm{ml}$ & $<62$ & $<50 \&<49$ & $<50$ & $<50$ & $<60 \&<48$ & $<50 \&<49$ \\
\hline Bromomothane & 74.83.9 & $002915.000 \mathrm{ng} / \mathrm{ml}$ & $<62$ & $<50 \&<49$ & $<50$ & $<50$ & $<50 \&<40$ & $<50 \&<49$ \\
\hline 1,1-Dichloraothene & $75-35-4$ & U078 $33.000 \mathrm{ng} / \mathrm{ml}$ & $<52$ & $<50 \&<49$ & $<50$ & $<50$ & $<60 \&<48$ & $<50 \&<49$ \\
\hline Acotone & 67.64-1 & $\begin{array}{l}F 003100,000 \mathrm{ng} / \mathrm{ml} \\
\text { U002 } 180,000 \mathrm{ng} / \mathrm{ml}\end{array}$ & $<52$ & $<50<<49$ & $<60$ & $<60$ & $<50 \&<46$ & $<50<<49$ \\
\hline Carbon Disulfide" & $75 \cdot 15$ & F005 N/A & 67 & $45 J \& 720$ & $<50$ & $<60$ & $<50<<4$ & $<50 \&<49$ \\
\hline Methylene Chlorida" & $76.09 \cdot 2$ & $\begin{array}{l}\text { FO02 } 33,000 \mathrm{ng} / \mathrm{ml} \\
\text { U080 } 33,000 \mathrm{ng} / \mathrm{ml}\end{array}$ & $<52$ & $<50 \&<49$ & $<50$ & $97^{\circ}$ & $130^{\circ} \& 140^{\circ}$ & $130^{\circ} \& 100^{\circ}$ \\
\hline trans-1.2.Dichloroethene & 168.60 .5 & U078 $33,000 \mathrm{ng} / \mathrm{ml}$ & $<52$ & $<50 \&<49$ & $<\infty 0$ & $<50$ & $<50 \&<46$ & $<50<<49$ \\
\hline 1.1. Dickloroethano & 75.34 .3 & $40767.200 \mathrm{ng} / \mathrm{ml}$ & $<52$ & $<50 \&<49$ & $<50$ & $<60$ & $<60 \&<46$ & $<50 \&<49$ \\
\hline cis-1,2-Dichloroethone & & N/A & $<52$ & $<50 \&<49$ & $<50$ & $<50$ & $<50 \&<46$ & $<60 \&<49$ \\
\hline $\begin{array}{c}\text { Mothyl Ethyl Kotons } \\
\text { [2-Butanonol }\end{array}$ & 78-93-3 & $\begin{array}{l}800538,000 \mathrm{no} / \mathrm{ml} \\
\text { U159 } 36,000 \mathrm{no} / \mathrm{ml}\end{array}$ & $<52$ & $<50 \&<49$ & $<50$ & $<50$ & $<60 \&<46$ & $<50 \&<49$ \\
\hline Chlorolorm" & 67-80-3 & U044 $6000 \mathrm{ng} / \mathrm{ml}$ & $<52$ & $<60 \&<49$ & $<50$ & $<50$ & $<60 \&<46$ & $<50 \&<49$ \\
\hline 1.1,1-Trichloroethane" & 71.66 .8 & $\begin{array}{l}F 0025800 \mathrm{ng} / \mathrm{ml} \\
\text { U2285600 ng/ml }\end{array}$ & $<62$ & $<50 \&<49$ & $<60$ & $<50$ & $<60 \&<48$ & $<60 \&<48$ \\
\hline Carbon Tatrechloride" & $66.23 \cdot 6$ & $U 2116000 \mathrm{ng} / \mathrm{ml}$ & $<52$ & $<50 \&<49$ & $<60$ & $<50$ & $<50 a<48$ & $<60 \&<49$ \\
\hline Bonzenie: & $7 \hat{i-43-2}$ & $\begin{array}{c}50063700 \mathrm{ng} / \mathrm{mr} \\
\text { U018 } 38,000 \mathrm{ng} / \mathrm{ml}\end{array}$ & $<\overline{b 2}$ & $<60<49$ & 620 & $<60$ & $<60 \&<4 \theta$ & $<60 \&<48$ \\
\hline 1.2-Dichloroethans & $107.08 \cdot 2$ & $00777,200 \mathrm{ng} / \mathrm{ml}$ & $<52$ & $<60 \&<49$ & $<50$ & $<60$ & $<50 \&<46$ & $<50 a<49$ \\
\hline Trichlorosthene" & $79.01 \cdot 0$ & $\begin{array}{l}F 0025600 \mathrm{ng} / \mathrm{ml} \\
\mathrm{U} 2285000 \mathrm{ng} / \mathrm{ml}\end{array}$ & $<62$ & $<60 \&<49$ & $<50$ & $<60$ & $<50 \&<46$ & $<50 \&<49$ \\
\hline 1.2-Dichloropropano & 78.87 .5 & U0B3 $18,000 \mathrm{ng} / \mathrm{ml}$ & $<52$ & $<50 \&<48$ & $<50$ & $<60$ & $<50 \&<46$ & $<50 \&<48$ \\
\hline Bromodichloromethene & 75.27 .4 & N/A & $<62$ & $<50 \&<49$ & $<60$ & $<50$ & $<50 \&<48$ & $<50 \&<49$ \\
\hline cis-1,3-Dichloropropeno & 10001.01 .6 & U084 $18,000 \mathrm{ng} / \mathrm{ml}$ & $<62$ & $<60 \&<49$ & $<50$ & $<50$ & $<50 \&<4 \theta$ & $<50<<49$ \\
\hline $\begin{array}{l}\text { Mothyl luobutyl Kotono } \\
\text { (4-Mothyl-2-Pontanono) }\end{array}$ & $108 \cdot 10 \cdot 1$ & $\begin{array}{l}F 00333,000 \mathrm{ng} / \mathrm{ml} \\
\text { U161 33,000 } \mathrm{ng} / \mathrm{ml}\end{array}$ & $<62$ & $<60 a<49$ & $<60$ & $<50$ & $<50 \&<46$ & $<50<<49$ \\
\hline Toluene & $108-88-3$ & $\begin{array}{l}\text { FO05 } 28,000 \mathrm{ng} / \mathrm{ml} \\
\mathrm{U} 22028,000 \mathrm{ng} / \mathrm{ml}\end{array}$ & $<52$ & $<60 \&<49$ & 670 & $<50$ & $<50 \&<46$ & $<50 \&<49$ \\
\hline
\end{tabular}


Table 19 (continued).

\begin{tabular}{|c|c|c|c|c|c|c|c|c|}
\hline Constituent & CAS Numbor & Rogulatory Limit & $\begin{array}{c}\text { Filtor } \# 1 \\
84-022110 \\
{[\mathrm{ng} / \mathrm{ml} \mid} \\
\end{array}$ & $\begin{array}{c}\text { Filter } \# 2 \\
94.022512 \\
\text { [ng/mull } \\
\end{array}$ & 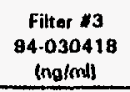 & $\begin{array}{c}\text { Filter } 14 \\
94.031126 \\
\text { (ng/ml] }\end{array}$ & $\begin{array}{c}\text { Filtor } \sharp 6 \\
94-03169 \\
\text { (ng/mli) } \\
\end{array}$ & $\begin{array}{c}\text { Filler } \# 6 \\
\text { 94.032822 } \\
\text { [ng/mil) }\end{array}$ \\
\hline Irans-1,3-Dichloropropona & 10081.02 .0 & $408418,000 \mathrm{ng} / \mathrm{ms}$ & $<52$ & $<608<49$ & $<50$ & $<60$ & $<50 \&<48$ & $<60 \&<49$ \\
\hline 1,1.2-Trichloroethane' & 79.00 .6 & $\begin{array}{l}F 0027600 \mathrm{ng} / \mathrm{ml} \\
\mathrm{U} 2275600 \mathrm{ng} / \mathrm{ml}\end{array}$ & $<52$ & $<50 \&<49$ & $<60$ & $<50$ & $<50 \&<46$ & $<60 \&<49$ \\
\hline Totrachioraothono" & $127.18-4$ & $\begin{array}{l}F 0025600 \mathrm{ng} / \mathrm{mll} \\
\text { U210 } 5600 \mathrm{ng} / \mathrm{ml}\end{array}$ & $<\boldsymbol{6 2}$ & $<60 \&<49$ & $<60$ & $<60$ & $<60 \&<40$ & $<50 \&<49$ \\
\hline 2-Hexanone & & N/A & $<52$ & $<60 \&<49$ & $x$ & $<60$ & $<50 \&<46$ & $<50 a<49$ \\
\hline Dibromochloromothane & & N/A & $<62$ & $<60 \&<49$ & $<50$ & $<60$ & $<50 \&<4 \theta$ & $<50 \&<49$ \\
\hline Chorobonzense & $108-90-7$ & $\begin{array}{l}F 0026700 \mathrm{ng} / \mathrm{ml} \\
00375700 \mathrm{ng} / \mathrm{ml}\end{array}$ & $<62$ & $<60 \&<49$ & $<60$ & $<60$ & $<60 \&<46$ & $<50 \&<49$ \\
\hline Ethylbenzono & $100-41-4$ & $F 0038,000 \mathrm{ng} / \mathrm{ml}$ & $<52$ & $<60 \&<49$ & $<50$ & $<60$ & $<60 \&<46$ & $<50 \&<49$ \\
\hline m-Xylone \& p-Xylono & 1330.20 .7 & $\begin{array}{l}\mathrm{F} 00328,000 \mathrm{ng} / \mathrm{ml} \\
U 23928.000 \mathrm{ng} / \mathrm{ml}\end{array}$ & $<52$ & $<60 \&<49$ & 107 & $<60$ & $<50 \&<4 B$ & $<60 \&<49$ \\
\hline o-Xylono & $1330-20-7$ & $\begin{array}{l}F 00328,000 \mathrm{ng} / \mathrm{ml} \\
423928,000 \mathrm{ng} / \mathrm{ml}\end{array}$ & $<62$ & $<60 \&<49$ & 265 & $<60$ & $<60 \&<46$ & $<50 \&<49$ \\
\hline Styrane & & N/A & $<62$ & $<608<49$ & 265 & $<50$ & $<60 \&<40$ & $<50 \&<49$ \\
\hline Bromatorm & $76-25-2$ & U225 $15,000 \mathrm{ng} / \mathrm{ml}$ & $<62$ & $<60 \&<49$ & $<60$ & $<60$ & $<60 \&<46$ & $<60 \&<49$ \\
\hline 1.1,2,2-Totrachloroothano & $79 \cdot 34 \cdot 6$ & $\mathrm{U} 20942,000 \mathrm{ng} / \mathrm{ml}$ & $<62$ & $<60 \&<49$ & $<60$ & $<60$ & $<50 \&<46$ & $<50 \&<49$ \\
\hline
\end{tabular}

These analyses were performed at ICPP laboratories 
Table 20. HFLS 1994 initial six filter media samples extracted by ZHE and analyzed by GC/MS.

\begin{tabular}{|c|c|c|c|c|c|c|c|c|}
\hline Constituont & CAS Number & Pegulatory Limit & $\begin{array}{c}\text { Filtor } \# 1 \\
94-022010 \\
\text { (ng/ml) }\end{array}$ & $\begin{array}{c}\text { Filter } 12 \\
94.022512 \\
(\mathrm{ng} / \mathrm{ml})\end{array}$ & $\begin{array}{c}\text { Filter } \# 3 \\
94.030418 \\
\text { (ng/ml) } \\
\end{array}$ & $\begin{array}{c}\text { Filter } 14 \\
94.031126 \\
\text { (no/mil) }\end{array}$ & $\begin{array}{c}\text { Filtor } \# 6 \\
94.03109 \\
\text { (ng/mit) }\end{array}$ & $\begin{array}{c}\text { Filter \#0 } \\
94.032822 \\
\text { (na/mil) }\end{array}$ \\
\hline Chloromothano & $74-87-3$ & U045 NIA & $<20$ & $<108<10$ & $<10$ & $<10$ & $<10$ & not nooded \\
\hline Vinyl Chloride & 76.01 .4 & $\begin{array}{l}\text { D043 } 200 \mathrm{ng} / \mathrm{ml} \\
\text { U043 N/A }\end{array}$ & $<20$ & $<10 \&<10$ & $<10$ & $<10$ & $<10$ & not noedad \\
\hline Bromomothano & 74.83 .8 & U028 N/A & $<20$ & $<10 a<10$ & $<10$ & $<10$ & $<10$ & not noeded \\
\hline 1,1.Dichloroethene & $75-35-4$ & $\begin{array}{c}0029700 \mathrm{nd} / \mathrm{md} \\
\text { U078 N/A }\end{array}$ & $<20$ & $<108<10$ & $<10$ & $<10$ & $<10$ & not neodiod \\
\hline Acotono & $07.04-1$ & U002 N/A & $<20$ & $11 \& 11$ & 130 & $<10$ & $230 E$ & not nooded \\
\hline Carbon Disulfide: & $75-15$ & $\begin{array}{l}\text { F005 } 4800 \mathrm{ng} / \mathrm{ml} \\
\text { PO22 N/A }\end{array}$ & $<20$ & $<10 \&<10$ & $<10$ & $<10$ & $<10$ & not neoded \\
\hline Mothyleno Chloride" & $75.09 \cdot 2$ & $\begin{array}{l}\text { FOO2 N/A } \\
\text { UOBO N/A }\end{array}$ & $<20$ & $<10 \&<10$ & $<10$ & $18 x$ & $19 x$ & not neodod \\
\hline Irans-1,2-Dichloroethone & $158 \cdot 60 \cdot 5$ & U079 N/A & $<20$ & $<10 \&<10$ & $<10$ & $<10$ & $<10$ & not nooded \\
\hline 1.1. Dichlaroothane & $75 \cdot 34 \cdot 3$ & U070 N/A & $<20$ & $<10 a<10$ & $<10$ & $<10$ & $<10$ & not nooded \\
\hline cis-1.2. Dichtoroathana & & U079 N/A & $<20$ & $<10 \&<10$ & $<10$ & $<10$ & $<10$ & not noodod \\
\hline $\begin{array}{c}\text { Mothyl Ethyl Ketone } \\
\text { (2-Butanune) }\end{array}$ & $78.93 \cdot 3$ & $\begin{array}{c}0036200,000 \mathrm{no} / \mathrm{ml} \\
\text { U169 N/A }\end{array}$ & 120 & $120 \& 120$ & 110 & 80 & 78 & not neoded \\
\hline Chloroform" & $67.66 \cdot 3$ & $\begin{array}{c}\mathrm{D} 0226000 \mathrm{no} / \mathrm{ml} \\
\mathrm{U} 044 \mathrm{~N} / \mathrm{A} \\
\end{array}$ & $<20$ & $<10 \&<10$ & $<10$ & $<10$ & $<10$ & not noodod \\
\hline 1,1,1-Trichloroothano" & $71 \cdot 65 \cdot 6$ & $\begin{array}{l}\text { F002 N/A } \\
\text { U226 N/A }\end{array}$ & $<20$ & $<10 \&<10$ & $<10$ & $<10$ & $<10$ & not noeded \\
\hline Carbon Tetrachloride' & $56-23.6$ & $\begin{array}{c}D 019500 \mathrm{ng} / \mathrm{ml} \\
\text { U211 N/A }\end{array}$ & $<20$ & $<10 \&<10$ & $<10$ & $<10$ & $<10$ & not noodod \\
\hline Benzena: & 71.43 .2 & $\begin{array}{c}\text { D018 } 600 \mathrm{ng} / \mathrm{ml} \\
\text { Fo05 N/A } \\
\text { U019 N/A }\end{array}$ & $<20$ & $<10 \&<10$ & $<10$ & $<10$ & $<10$ & not neoded \\
\hline 1.2.Dichloroesthanto & 107.08 .2 & $\begin{array}{l}\text { D028 } 600 \mathrm{na} / \mathrm{mt} \\
\text { U077 N/A }\end{array}$ & $<20$ & $<10 \&<10$ & $<10$ & $<10$ & $<10$ & not noodod \\
\hline Trichlorosthene" & $79.01 \cdot 6$ & $\begin{array}{c}0040600 \mathrm{ng} / \mathrm{ml} \\
F 002 \mathrm{~N} / \mathrm{A} \\
\text { U228 N/A }\end{array}$ & $<20$ & $<108<10$ & $<10$ & $<10$ & $<10$ & not neodod \\
\hline 1,2.Dichloropropane & 78.97 .6 & VOB3 N/A & $<20$ & $<108<10$ & $<10$ & $<10$ & $<10$ & not noodod \\
\hline Aromodichloromethano & 76.27 .4 & N/A & $<20$ & $<10 \&<10$ & $<10$ & $<10$ & $<10$ & not nooded \\
\hline cis-1,3-Dichloropropene & $10081.01-5$ & U084 N/A & $<20$ & $<10 \&<10$ & $<10$ & $<10$ & $<10$ & not noodod \\
\hline
\end{tabular}


Table 20 (continued).

\begin{tabular}{|c|c|c|c|c|c|c|c|c|}
\hline Constituent & CAS Number & Regulatory Limit & $\begin{array}{c}\text { Filtor \#1 } \\
94-022010 \\
(\mathrm{ng} / \mathrm{ml})\end{array}$ & $\begin{array}{c}\text { Filter } \# 2 \\
84-022612 \\
\text { (nglml) }\end{array}$ & $\begin{array}{c}\text { Filker } \$ 3 \\
94-030418 \\
(\mathrm{ng} / \mathrm{mil}) \\
\end{array}$ & $\begin{array}{c}\text { Filter } \# 4 \\
94-031126 \\
\text { (ng/m) }\end{array}$ & $\begin{array}{c}\text { Fittor } 115 \\
94.03169 \\
\text { (no/mli }\end{array}$ & $\begin{array}{l}\text { Filter \#6 } \\
94.032822 \\
{[\mathrm{ng} / \mathrm{ml}]}\end{array}$ \\
\hline $\begin{array}{l}\text { Methly Is obutyl Kotone } \\
\text { (4-Methyl-2-Pontanonol }\end{array}$ & 108.10 .1 & $\begin{array}{l}\text { Fo03 N/A } \\
\text { U161 N/A }\end{array}$ & $<20$ & $<10<10$ & $<10$ & $<10$ & $<10$ & not nooded \\
\hline Toluane & $108-88-3$ & $\begin{array}{l}F 006 \text { N/A } \\
\text { U220 N/A }\end{array}$ & $<20$ & $<10 \&<10$ & $<10$ & $<10$ & $<10$ & not neoded \\
\hline Irane-1,3-Dichlorapropone & 10061.02 .8 & $0084 \mathrm{~N} / \mathrm{A}$ & $<20$ & $<10 \&<10$ & $<10$ & $<10$ & $<10$ & not neodad \\
\hline 1,1,2-Trichloroethanne" & 79.00 .5 & $\begin{array}{l}\text { Fo02 N/A } \\
\text { U227 N/A }\end{array}$ & $<20$ & $<10 \&<10$ & $<10$ & $<10$ & $<10$ & not nooded \\
\hline Totrachtoroethene" & $127-18-4$ & $\begin{array}{l}0039700 \mathrm{ng} / \mathrm{ml} \\
F 002 \mathrm{~N} / \mathrm{A} \\
\text { U210 N/A }\end{array}$ & $<20$ & $<10 \&<10$ & $<10$ & $<10$ & $<10$ & not nooded \\
\hline 2-Hoxanono & & N/A & $<20$ & $<10 \&<10$ & $<10$ & $<10$ & $<10$ & not noodod \\
\hline Dibromochloromethane & & N/A & $<20$ & $<10 \&<10$ & $<10$ & $<10$ & $<10$ & not nooded \\
\hline Chlorobonzeno & $108-80-7$ & $\begin{array}{c}D 021100,000 \mathrm{ng} / \mathrm{ml} \\
1002 \mathrm{~N} / \mathrm{A} \\
0037 \mathrm{~N} / \mathrm{A}\end{array}$ & $<20$ & $<10<10$ & $<10$ & $<10$ & $<10$ & not nooded \\
\hline Ethylbenzano & $100-41-4$ & FOO3 N/A & $<20$ & $<10 \&<10$ & $<10$ & $<10$ & $<10$ & not noodod \\
\hline$m$-Xylono \& p-Xylono & $1330-20-7$ & $\begin{array}{l}\text { Foo3 N/A } \\
\text { U239 N/A }\end{array}$ & $<20$ & $<10 \&<10$ & $<10$ & $<10$ & $<10$ & not nooded \\
\hline a-Xylene & $1330 \cdot 20.7$ & $\begin{array}{l}\text { F003 N/A } \\
\text { U239 N/A }\end{array}$ & $<20$ & $<10<<10$ & $<10$ & $<10$ & $<10$ & not nooded \\
\hline Styrene & & N/A & $<20$ & $<10 \&<10$ & $<10$ & $<10$ & $<10$ & not noodod \\
\hline Bromotorm & 76.26 .2 & U225 N/A & $<20$ & $<10 \&<10$ & $<10$ & $<10$ & $<10$ & not nooded \\
\hline 1.1,2,2-Yotrachloroathane & 79.34 .6 & U200 N/A & $<20$ & $<10 \&<10$ & $<10$ & $<10$ & $<10$ & not noedod \\
\hline
\end{tabular}

- Insoluable organics idantified in the HFLS Wasto Analvale Plan (WAP) that require roculatory detormination.

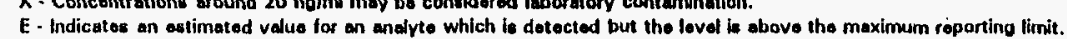

These analyses were performed at ICPP laboratories 
Table 21. HFLS 1994 filter media samples repulled and ran for total analysis by GC/MS.

\begin{tabular}{|c|c|c|c|c|}
\hline Constituent & CAS Numbor & Reguletory Limit & $\begin{array}{c}\text { Filtor } * 1 \\
84-072716 \\
\text { (ngo/mit) } \\
\end{array}$ & $\begin{array}{c}\text { Filhor } \| 2 \\
84.072717 \\
(\mathrm{ng} / \mathrm{m})\end{array}$ \\
\hline Chloromathane & $74-87 \cdot 3$ & $004633,000 \mathrm{ng} / \mathrm{ml}$ & $<10$ & $<10 \&<10$ \\
\hline Vinyl Chloride & $76-01 \cdot 4$ & $004333,000 \mathrm{ng} / \mathrm{ml}$ & $<10$ & $<10 \&<10$ \\
\hline Bromamethane & 74.83 .9 & $002816,000 \mathrm{ng} / \mathrm{ml}$ & $<10$ & $<10 \&<10$ \\
\hline 1,1-Dichloroethene & 76-35.4 & $007833,000 \mathrm{ng} / \mathrm{mt}$ & $<10$ & $<10 \&<10$ \\
\hline Acotone & 87-84-1 & $\begin{array}{l}F 003160,000 \mathrm{ng} / \mathrm{ml} \\
0002100,000 \mathrm{ng} / \mathrm{mm}\end{array}$ & $<10$ & $118<10$ \\
\hline Carbon Disullide" & $75-15$ & F005 N/A & $<10$ & $<10 \&<10$ \\
\hline Methyleno Chloride" & 75.09-2 & $\begin{array}{l}5002,33,000 \mathrm{ng} / \mathrm{ml} \\
008033,000 \mathrm{ng} / \mathrm{mm}\end{array}$ & $<10$ & $<10 \&<10$ \\
\hline trane-1.2. Dichloroethene & $150 \cdot 80-5$ & $007933.000 \mathrm{ng} / \mathrm{md}$ & $<10$ & $<10 \&<10$ \\
\hline 1.1. Dichloroathane & 76.34.3 & $00787.200 \mathrm{ng} / \mathrm{mt}$ & $<10$ & $<108<10$ \\
\hline cis-1,2-Dichloraathana & & N/A & $<10$ & $<10 \&<10$ \\
\hline $\begin{array}{c}\text { Mathy) Ethy) Kotons } \\
\text { (2-Butananool }\end{array}$ & 78-83.3 & $\begin{array}{r}F 00536,000 \mathrm{ng} / \mathrm{ml} \\
\text { U1593 36,000 } \mathrm{ng} / \mathrm{ml} \\
\end{array}$ & $<10$ & $<10 \&<10$ \\
\hline CMloroform & 87.68.3 & $00445800 \mathrm{ng} / \mathrm{ml}$ & $<10$ & $<10 \&<10$ \\
\hline 1,1,1-Trichloroothane " & $71-66.8$ & $\begin{array}{l}50026800 \mathrm{ng} / \mathrm{mt} \\
02286800 \mathrm{ng} / \mathrm{mt}\end{array}$ & $<10$ & $<10 \&<10$ \\
\hline Carbon Totrachlorido" & 58.23.5 & $02115600 \mathrm{ng} / \mathrm{mt}$ & $<10$ & $<10 \&<10$ \\
\hline Benzena" & ?1-43-2 & $\begin{array}{r}F 0053700 \mathrm{ng} / \mathrm{ml} \\
401838,000 \mathrm{ng} / \mathrm{mt} \\
\end{array}$ & $<10$ & $<10 \&<10$ \\
\hline 1.2-Dichlorosthane & $107.00 \cdot 2$ & $00777.200 \mathrm{ng} / \mathrm{ml}$ & $\leq 10$ & $<108<10$ \\
\hline Trichlorosthano" & $79.01-6$ & $\begin{array}{l}F 0025600 \mathrm{ng} / \mathrm{m} / \\
\mathrm{U} 2285800 \mathrm{ng} / \mathrm{m}\end{array}$ & $<10$ & $<108<10$ \\
\hline 1.2-Dichloropropenene & $78-87.5$ & U0B3 $18,000 \mathrm{ng} / \mathrm{mt}$ & $\leqslant 10$ & $<10 \&<10$ \\
\hline Bromadichloramethano & 76-27.4 & N/A & $<10$ & $<108<10$ \\
\hline cie-1.3. Dichloroppropene & 10001.01 .5 & $008418.000 \mathrm{ng} / \mathrm{ml}$ & $<10$ & $<10 \&<10$ \\
\hline 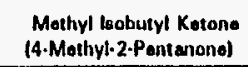 & 108.10.1 & $\begin{array}{l}\text { Fo03 } 33,000 \mathrm{ng} / \mathrm{mt} \\
\text { U161 } 33,000 \mathrm{ng} / \mathrm{ml}\end{array}$ & $<10$ & $<10 \&<10$ \\
\hline
\end{tabular}


Table 21 (continued).

\begin{tabular}{|c|c|c|c|c|}
\hline Constituont & CAS Numbor & Rogulatoory Limit & $\begin{array}{c}\text { Fillter \#1 } \\
84-072715 \\
\text { (nog/mint) } \\
\end{array}$ & $\begin{array}{c}\text { Fithor \#2 } \\
94.072717 \\
\text { tog } / \mathrm{mul} 11 \\
\end{array}$ \\
\hline Toluene & $108-88-3$ & 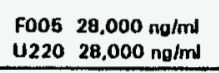 & $<10$ & $<10 \&<10$ \\
\hline trane- 1.3. Dichlaropropene & $10001.02-8$ & $008418,000 \mathrm{ng} / \mathrm{m} \mathrm{d}$ & $<10$ & $<10 a<10$ \\
\hline 1.1.2-Trichloroothano" & $79 \cdot 00.6$ & $\begin{array}{r}F 0027800 \mathrm{no} / \mathrm{ml} \\
\mathrm{U} 2276800 \mathrm{ng} / \mathrm{ml} \\
\end{array}$ & $<10$ & $<10<<10$ \\
\hline Totrachloroethone " & $127 \cdot 18 \cdot 4$ & $\begin{array}{l}50026600 \mathrm{ng} / \mathrm{ml} \\
\mathrm{U} 105600 \mathrm{~g} / \mathrm{mg} / \mathrm{m}\end{array}$ & $<10$ & $<10<<10$ \\
\hline 2.Hoxanone & & N/A & $7.4 \mathrm{~J}$ & $9.3\lrcorner \&<10$ \\
\hline Dibromochloromothane & & N/A & $<10$ & $<10 \&<10$ \\
\hline Chlorobonzano & 108-90.7 & $\begin{array}{l}F 0025700 \mathrm{ng} / \mathrm{ml} \\
00375700 \mathrm{ng} / \mathrm{ml}\end{array}$ & $<10$ & $<10 \&<10$ \\
\hline Ethyibonzone & $100 \cdot 41-4$ & $F 0030.000 \mathrm{ng} / \mathrm{ml}$ & $<10$ & $<10 \&<10$ \\
\hline m-Xylono \& p-Xylona & 1330.20 .7 & $\begin{array}{r}F 00328,000 \mathrm{ng} / \mathrm{ms} \\
423928.000 \mathrm{ng} / \mathrm{m} / \\
\end{array}$ & $<10$ & $<10 \&<10$ \\
\hline o-Xylone & 1330-20-7 & $\begin{array}{r}F 00328.000 \mathrm{ng} / \mathrm{ml} \\
\mathbf{U 2 3 3} 28.000 \mathrm{ng} / \mathrm{ml}\end{array}$ & $<10$ & $<10 \&<10$ \\
\hline Styrens: & & N/A & $<10$ & $<10 \&<10$ \\
\hline Bromotorm & $76 \cdot 26 \cdot 2$ & $\mathbf{U 2 2 6} 16.000 \mathrm{ng} / \mathrm{mt}$ & $<10$ & $<10 \&<10$ \\
\hline 1,1,2,2-Tatrachloroothane & 29-34.6 & $U 20842,000 \mathrm{no} / \mathrm{mt}$ & $<10$ & $<10 \&<10$ \\
\hline
\end{tabular}

- Insoluable organice identiliod in tha HFLS Wasto Analysis Plan (WAP) that roquire regulatory dotormination.

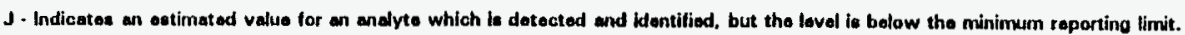


Table 22. Six HFLS filter leachate/rinsate samples analyzed in 1994 for RCRA volatile organic carbons.

\begin{tabular}{|c|c|c|c|c|c|c|c|c|c|c|c|}
\hline Consitituent & CAS Number & $\begin{array}{l}\text { Regulatory } \\
\text { Lmit }\end{array}$ & $\begin{array}{l}\text { Baselline } \\
\text { Rinse } \\
\text { git01 } \\
\end{array}$ & \begin{tabular}{|l} 
M1 Rinse \\
94022012 \\
ppb
\end{tabular} & 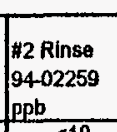 & \begin{tabular}{|l} 
\%3 Rinse \\
94030415 \\
$p p b$
\end{tabular} & $\begin{array}{l}\text { Duppricale } \\
\text { *3 Rinse } \\
\text { 94-030415 } \\
\text { ppb } \\
\end{array}$ & \begin{tabular}{|l}
$\begin{array}{c}* 4 \\
\text { 9 Rinse } \\
94031121 \\
\text { ppb }\end{array}$ \\
\end{tabular} & $\begin{array}{l}\text { Duppicale } \\
\text { \#4 Rinse } \\
94031121 \\
\text { ppb }\end{array}$ & $\begin{array}{l}\begin{array}{l}45 \text { Rinse } \\
94.03167 \\
\text { ppb }\end{array} \\
\text { pp }\end{array}$ & \begin{tabular}{|l} 
W6 Rinse \\
94032819 \\
ppp
\end{tabular} \\
\hline Chloromethane & $74-87-3$ & & & & & & & & & & \\
\hline Vinyl Chloride & $75-01-4$ & {$\left[\begin{array}{l}0043 \\
0043270 \mathrm{ppb}\end{array}\right.$} & $<10$ & $<10$ & $<10$ & $<10$ & $<10$ & $<10$ & $<10$ & $<10$ & $<10$ \\
\hline Bromomethane & $74-83-9$ & $002910 \mathrm{ppb}$ & $\leq 10$ & $<10$ & $<10$ & $\leq 10$ & 410 & 410 & $<10$ & $<10$ & 410 \\
\hline 1.1-Dlchloroethene & $75-35-4$ & $\begin{array}{l}0029708 \mathrm{ppb} \\
\text { U078 } 25 \mathrm{ppb}\end{array}$ & $<10$ & $<10$ & $<10$ & $<10$ & $<10$ & $<10$ & $<10$ & $<10$ & $<10$ \\
\hline Acelone & $67-64.1$ & $\begin{array}{l}F 003280 \mathrm{pph} \\
\mathrm{U} 002280 \mathrm{ppb}\end{array}$ & $<10$ & 136 & 47 & $<10$ & $<10$ & 33 & 16 & $<10$ & $<10$ \\
\hline Carbon Disulfice & $75-15$ & \begin{tabular}{|l|}
$F 00514 \mathrm{ppb}$ \\
P022 14 ppb
\end{tabular} & $<10$ & $<10$ & $<10$ & $<10$ & $<10$ & $<10$ & $<10$ & $<10$ & $<10$ \\
\hline Methylene Chloride" & $75-09-2$ & 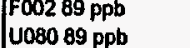 & $<10$ & $<10$ & $<10$ & $<10$ & $<10$ & $<10$ & 11 & $<10$ & 19 \\
\hline 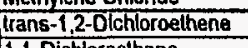 & $\frac{1}{156-60.5}$ & Uat7954 ppo & $<10$ & 410 & $\leq 10$ & $\leq 10$ & $<10$ & $<10$ & $<10$ & $<10$ & $<10$ \\
\hline 1,1-Dichloroelhane & $\frac{15-343}{7545}$ & $070759 \mathrm{ppb}$ & $\leq 10$ & $<10$ & $<10$ & 510 & $<10$ & $\frac{810}{610}$ & -10 & 510 & $<10$ \\
\hline $\begin{array}{l}\text { Methyl Euhy Ketotone } \\
\text { (2-Butanone) }\end{array}$ & 78-93-3 & $\begin{array}{l}\text { NA } \\
0035200,000 \mathrm{ppb} \\
\text { F005 280 ppb } \\
1159280 \mathrm{ppb}\end{array}$ & $\leq 10$ & $<10$ & $<10$ & $<10$ & $<10$ & $<10$ & $<10$ & $<10$ & $<10$ \\
\hline Chlorolorm: & $67-66-3$ & $\begin{array}{l}00256000 \mathrm{ppb} \\
0.04446 \mathrm{ppb}\end{array}$ & $<10$ & $<10$ & $<10$ & $<10$ & $<10$ & $<10$ & $<10$ & $<10$ & $<0$ \\
\hline 1,1,1-Trichloroethane" & $71-55-6$ & $\begin{array}{l}F 002544 \mathrm{ppb} \\
\text { U222654 ppb }\end{array}$ & $<10$ & $<10$ & $<10$ & $<10$ & $<10$ & $\$ 10$ & $<10$ & $<10$ & $<10$ \\
\hline Carbon Telrachloride* & $56-23-5$ & $\begin{array}{l}\text { Dorgsou ppb } \\
\text { Fo02 57 ppb } \\
\text { L } 21157 \mathrm{ppb}\end{array}$ & $<10$ & $<10$ & $<10$ & $<10$ & $<10$ & $<10$ & $<10$ & $<10$ & 50 \\
\hline Benzene: & $71-43-2$ & 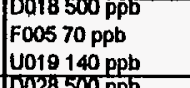 & $<10$ & $<10$ & $<10$ & $<10$ & $<10$ & $<10$ & $<10$ & $<10$ & $<10$ \\
\hline 1,2-Dichloroethane & $107-06.2$ & $\begin{array}{l}0.28500 \mathrm{ppb} \\
\text { uor7 } 210 \mathrm{ppb}\end{array}$ & $<10$ & $<10$ & $<10$ & $<10$ & $<10$ & $<10$ & $<10$ & $<10$ & $<10$ \\
\hline Trichloroethene" & $79.01 \cdot 6$ & 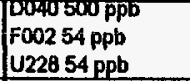 & $<10$ & $<10$ & $<10$ & $<10$ & $<10$ & $<10$ & $<10$ & $<10$ & $<10$ \\
\hline $\begin{array}{l}\text { 1,2-Dlchloropropane } \\
\text { Brocomodichloromethane }\end{array}$ & $\frac{78-87-5}{75-27-4}$ & $\frac{1}{4083850 \mathrm{ppb}}$ & $\frac{<10}{<10}$ & $\frac{<10}{<10}$ & $\frac{410}{510}$ & $<10$ & $\frac{310}{510}$ & $<\frac{<10}{<10}$ & $-\frac{10}{10}$ & $<10$ & $\frac{410}{40}$ \\
\hline 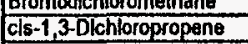 & $\frac{10-21404-5}{10061-01-5}$ & पat & $\frac{40}{410}$ & $\frac{10}{<10}$ & $\frac{510}{410}$ & $\frac{10}{<10}$ & $\frac{410}{40}$ & $\frac{10}{10}$ & $\frac{<10}{<10}$ & $\frac{<10}{410}$ & $\frac{410}{10}$ \\
\hline 4-Melhy-2-Pentanone & $108-10-1$ & $\begin{array}{l}F 003740 \mathrm{ppb} \\
U 161140 \mathrm{ppb}\end{array}$ & $<10$ & 18 & 17 & 13 & 13 & 11 & 11 & 13 & 11 \\
\hline Toluene & 108-80-33 & $\mid \begin{array}{l}F 00580 \mathrm{ppb} \\
\mathrm{U} 22080 \mathrm{ppb}\end{array}$ & $<10$ & $<10$ & $<10$ & $<10$ & $<10$ & $<10$ & $<10$ & $<10$ & $<10$ \\
\hline
\end{tabular}


Table 22 (continued).

\begin{tabular}{|c|c|c|c|c|c|c|c|c|c|c|c|}
\hline Constiluent & CAS Number & $\begin{array}{l}\text { Regulatory } \\
\text { Limit }\end{array}$ & $\begin{array}{l}\text { Baseline } \\
\text { Rinse } \\
\text { 94-01 } \\
\end{array}$ & $\begin{array}{l}\text { \#1 Rinse } \\
94-022012 \\
\text { ppb }\end{array}$ & $\begin{array}{l}\text { \#2 Rinse } \\
94-02259 \\
\mathrm{ppb}\end{array}$ & $\begin{array}{l}\text { \#3 Rinse } \\
94-030415 \\
\text { ppb }\end{array}$ & $\begin{array}{l}\text { Tupicale } \\
\text { Fu Rinse } \\
94-030415 \\
\text { ppb }\end{array}$ & $\begin{array}{l}\text { H4 Rinse } \\
94031121 \\
\mathrm{ppb}\end{array}$ & $\begin{array}{l}\text { Dupreare } \\
\text { in Rinse } \\
94031121 \\
\text { ppb }\end{array}$ & $\begin{array}{l}\text { \#5 Rinse } \\
94-03167 \\
\text { ppb }\end{array}$ & $\begin{array}{l}\text { \#6 Rinse } \\
94-032819 \\
\text { ppb }\end{array}$ \\
\hline Irans-1,3-Dichloropropene & $10061-02-6$ & $008436 \mathrm{ppb}$ & $\leq 10$ & $<10$ & $<10$ & $<10$ & $<10$ & $<10$ & 510 & $<10$ & $<10$ \\
\hline 1.1,2-Trichloroethane* & $79-00-5$ & $\begin{array}{l}F 00230 \mathrm{ppb} \\
\text { U227 } 54 \mathrm{ppb}\end{array}$ & $<10$ & $<10$ & $<10$ & $<10$ & $<10$ & $<10$ & $<10$ & $<10$ & $<10$ \\
\hline Tetrachloroethene ${ }^{\circ}$ & $127-18-4$ & $\begin{array}{l}\text { DO39700 pps } \\
\text { F002 56 ppb } \\
\text { U210 56 ppb }\end{array}$ & $<10$ & $<10$ & $<10$ & $<10$ & $<10$ & $<10$ & $<10$ & $<10$ & $<10$ \\
\hline 2-Hexanone & $591-78-6$ & NA & $\$ 10$ & $\leqslant 10$ & 410 & $\leq 10$ & $\leqslant 10$ & $<10$ & $<10$ & $<10$ & $<10$ \\
\hline Dibromochloromethane & $124-48-1$ & NA & $\leqslant 10$ & 510 & $\leq 10$ & $<10$ & $\leq 10$ & $\leq 10$ & $<10$ & 510 & $<10$ \\
\hline Chlorobenzene & 108-90-7 & $\begin{array}{l}F 00251 \text { ppb } \\
\text { D021 } 100,000 \mathrm{ppb} \\
\text { U037 } 57 \mathrm{ppb}\end{array}$ & $<10$ & $<10$ & $<10$ & $<10$ & $<10$ & $<10$ & $<10$ & $<10$ & $<10$ \\
\hline Eihylbenzene & $100-41-4$ & $F 00357 \mathrm{ppb}$ & $\leq 10$ & $\leqslant 0$ & $\leq 10$ & $<10$ & $<10$ & $\leq 10$ & $<10$ & 510 & $<10$ \\
\hline m-Xylene \& p-Xylene & $1330-20-7$ & $\begin{array}{l}\text { F003320 ppb } \\
\text { U239 320 ppb }\end{array}$ & $<10$ & $<10$ & $<10$ & $<10$ & $<10$ & $<10$ & $<10$ & $<10$ & $<10$ \\
\hline $0-$ Xylene & $1330-20-7$ & $\begin{array}{l}F 03320 \mathrm{ppb} \\
\mathrm{U} 239320 \mathrm{ppb}\end{array}$ & $<10$ & $<10$. & $<10$ & $<10$ & $<10$ & $<10$ & $<10$ & $<10$ & $<10$ \\
\hline Styrene & $100-42-5$ & NA & $<10$ & 510 & $<10$ & $<10$ & $<10$ & $<10$ & $\varangle 10$ & $<10$ & $<10$ \\
\hline Bromoform & $75-25-2$ & $\mathrm{U} 225630 \mathrm{ppb}$ & $\leq 10$ & 210 & $<10$ & $<10$ & $\leqslant 10$ & $<10$ & $\leqslant 10$ & $<10$ & 510 \\
\hline 1,1,2,2-Telrachloroethane & $79.34-6$ & $020957 \mathrm{ppb}$ & $<10$ & $<10$ & $<10$ & $<10$ & $<10$ & $<10$ & $<10$ & $<10$ & $<10$ \\
\hline
\end{tabular}

- Insoluble organics identified in the HFLS Waste Analysis Plan (WAP) as requiring a regulatory determination.

In all tables, "rinse" means a composite sample of leachate and rinsate from vessel VES-NCD-123. 
Table 23. Six HFLS filter media samples analyzed for RCRA semi-volatile organic carbons in 1994.

\begin{tabular}{|c|c|c|c|c|c|c|c|c|}
\hline Constltuent & CAS Number & $\frac{\text { Regulatory LImit }}{\mathrm{ppb}}$ & $\frac{\text { Sample \#1 }}{94-072715}$ & $\frac{\text { Sample *2 }}{84-072717}$ & $\frac{\text { Sample *3 }}{04-072714}$ & $\frac{\text { Sample \#4 }}{94-072713}$ & $\frac{\text { Sample } 45}{94-072712}$ & $\frac{\text { Sample } 6}{94-072711}$ \\
\hline & & & $\mathrm{ppb}$ & $\mathrm{ppb}$ & $\mathrm{ppb}$ & $\mathrm{ppb}$ & $\rho p b$ & $p p b$ \\
\hline n-Nitrosodlmethylamine & $62-75-9$ & POB2 NA & $<10$ & $<10$ & $<10$ & $<10$ & $<10$ & $<10$ \\
\hline Phenol & 100.95 .2 & U188 6200 & $<10$ & $<10$ & $<10$ & $<10$ & $\angle 10$ & $\leq 10$ \\
\hline bls(2-Chloroethyl) Ether & $111-44-4$ & 00257200 & $\leq 10$ & $<10$ & $\leq 10$ & $\leq 10$ & $\leq 10$ & $\leq 10$ \\
\hline 2-Chlorophenol & $95-57-8$ & U048 5700 & $<10$ & $<10$ & $<10$ & $<10$ & $<10$ & 610 \\
\hline 1,3-Dichlorobenzene & $541.73-1$ & 00716200 & $\leqslant 10$ & 510 & $<10$ & $<10$ & $\leq 10$ & $\leqslant 10$ \\
\hline 1,4-Dichlorobenzene & $106-46-7$ & 00726200 & $\leq 10$ & $<10$ & $<10$ & $<10$ & $<10$ & $\leq 10$ \\
\hline 1,2-Dichlorobenzene & $95-50-1$ & $\begin{array}{ll}0070 & 6200 \\
0027 & 7500 \\
\end{array}$ & $<10$ & $<10$ & $<10$ & $<10$ & $<10$ & $<10$ \\
\hline 2-Melhylphenol & $95-48-7$ & \begin{tabular}{|ll}
0552 & 5600 \\
0023 & 200000 \\
\end{tabular} & $<10$ & $<10$ & $<10$ & $<10$ & $<10$ & $<10$ \\
\hline $\begin{array}{l}\text { 2,20xybla(1- } \\
\text { Chloropropane) }\end{array}$ & & NA & $\leq 10$ & $\leq 10$ & $<10$ & $<10$ & $<10$ & $\leq 10$ \\
\hline -Nitroso-dl-n-propylamlne & 621.647 & U111 14000 & $\leq 10$ & $<10$ & $<10$ & $<10$ & $<10$ & $<10$ \\
\hline 3 \& 4 methylphenol & $\begin{array}{l}108-39-4 \\
106-44-5\end{array}$ & $\begin{array}{|ll|}0052 & 3200 \\
0024 & 200000 \\
0025 & 200000 \\
\end{array}$ & $<10$ & $<10$ & $<10$ & $<10$ & $<10$ & $<10$ \\
\hline Hexachloroethane & $67-72-1$ & \begin{tabular}{|ll}
1131 & 28000 \\
0034 & 3000 \\
034
\end{tabular} & $<10$ & $<10$ & $<10$ & $<10$ & $<10$ & $<10$ \\
\hline Nitrobenzene & $98-95.3$ & \begin{tabular}{|lc}
169 & 14000 \\
0036 & 2000 \\
\end{tabular} & $\leq 10$ & $<10$ & $<10$ & $<10$ & $<10$ & $<10$ \\
\hline lsophorone & & NA & $<10$ & $<10$ & $<10$ & 410 & $<10$ & $<10$ \\
\hline 2-Nitrophenol & $88-75.5$ & NA & $\leq 10$ & $<10$ & $<10$ & $\leq 10$ & 510 & $<10$ \\
\hline 2,4-Dimethyiphenol & $105-67-9$ & U101 14000 & $<10$ & $<10$ & $<10$ & $<10$ & 610 & $<10$ \\
\hline bis(2-chlorethoxy)methane & $111-91-1$ & NA & $<10$ & $<10$ & $<10$ & $<10$ & $<10$ & $<10$ \\
\hline 2,4-Dichlorophenol & $120-83-2$ & $4001 \quad 14000$ & 510 & $\leqslant 10$ & $<10$ & $<10$ & $<10$ & $<10$ \\
\hline 1,2,4-Trlchlorobenzene & $120-82-1$ & NA & 510 & $\leqslant 10$ & $<10$ & $<10$ & $<10$ & $<10$ \\
\hline Naphthalene & $91.20-3$ & 01653100 & $\leq 10$ & $<10$ & $<10$ & $<10$ & $<10$ & $\leq 10$ \\
\hline 4 -Chioroanilline & $106-47-8$ & P024 16000 & $<10$ & $\leq 10$ & $<10$ & $<10$ & $<10$ & $\leq 10$ \\
\hline Hexachlorobutadlene & $07-60.3$ & $\begin{array}{|ll|}128 & 28000 \\
0033 & 500 \\
\end{array}$ & $<10$ & $<10$ & $<10$ & $<10$ & $<10$ & $<10$ \\
\hline 4-Chioro-3-Methylphenol & $59-50-7$ & NA & $<10$ & $<10$ & $<10$ & $<10$ & $<10$ & $\leqslant 10$ \\
\hline 2-Methylnaphthaleno & 91.57 .6 & NA & $<10$ & $<10$ & $<10$ & $<10$ & $<10$ & $<10$ \\
\hline Hexachlorocyclopentadlene & $\pi-47-4$ & $0130 \quad 3600$ & 510 & $<10$ & $<10$ & $<10$ & $<10$ & $<10$ \\
\hline 2,4,5-Trlahlorophenol & $95.95-4$ & 0041400000 & $<10$ & $<10$ &.$<10$ & $<10$ & $\leq 10$ & $<10$ \\
\hline 2,4,6-Trichlorophenol & $88-06-2$ & 00422000 & $<10$ & $\leq 10$ & $<10$ & $<10$ & $<10$ & $<10$ \\
\hline 2-chloronaphthalene & 91.58 .7 & $0047 \quad 5600$ & $<10$ & $<10$ & $<10$ & $<10$ & $\leqslant 10$ & $<10$ \\
\hline 2-NitroanilIne & $88-74-4$ & NA & $<10$ & $<10$ & $\leqslant 10$ & $<10$ & $<10$ & $\leq 10$ \\
\hline Dimethyl phthalato & $131-11-3$ & 010228000 & $<10$ & $<10$ & $\leq 10$ & $<10$ & $<10$ & $<10$ \\
\hline 2,6-Dlnltrotoluene & $606-20-2$ & U106 28000 & $<10$ & $\leq 10$ & $<10$ & $\leq 10$ & $<10$ & $<10$ \\
\hline Acenapthylene & $208-96-8$ & NA & $<10$ & $<10$ & $<10$ & $<10$ & $<10$ & $<10$ \\
\hline 3. NIIroanllino & $99-09-2$ & NA & $<10$ & $<10$ & $<10$ & $<10$ & $<10$ & $<10$ \\
\hline
\end{tabular}


Table 23 (continued).

\begin{tabular}{|c|c|c|c|c|c|c|c|c|}
\hline Constlluent & CAS Number & Regulatory LImit & Sample :1 & Sample:2 & Sample :3 & Sample 14 & Sample :5 & Sample \#8 \\
\hline & & & $\frac{84-0 / 2 / 15}{\mathrm{ppb}}$ & $\frac{94-0 / 26117}{\mathrm{ppb}}$ & $\frac{84-0 / 2 / 14}{\mathrm{ppb}}$ & $\frac{94-072713}{\mathrm{ppb}}$ & $\frac{94-072712}{\mathrm{ppb}}$ & $\frac{84-072711}{\mathrm{ppb}}$ \\
\hline Acenaphthene & $83-32-9$ & $\mathrm{NA}$ & $<10$ & $<10$ & $<10$ & $\leqslant 10$ & $<10$ & $<10$ \\
\hline 2,4-Dinitrophenol & $51-28-5$ & $P 048 \quad 160000$ & $<10$ & $<10$ & $<10$ & $<40$ & $<10$ & $<10$ \\
\hline 4-Nitrophenol & $100-02-7$ & $0170 \quad 29000$ & $<10$ & 13 & 150 & 34 & 93 & 12 \\
\hline Dlbenzofuran & $132-64-98$ & NA & $\leq 10$ & $<10$ & $<10$ & $\leq 10$ & $<10$ & $<10$ \\
\hline 2,4-DInitrotoluene & $121-14-2$ & $\begin{array}{|ll|}106 & 140000 \\
0030 & 130 \\
\end{array}$ & $<10$ & $<10$ & $<10$ & $<10$ & $<10$ & $<10$ \\
\hline Diethyl phthalate & $8466-2$ & 408828000 & $<10$ & $<10$ & $<10$ & $<10$ & $<10$ & $<10$ \\
\hline Fluorene & $206-44-0$ & $N A$ & $<10$ & $\leq 10$ & $<10$ & $<10$ & $<10$ & $<10$ \\
\hline 4-Chlorophenylphenyl Ether & 7005.72 .3 & NA & $<10$ & $<10$ & $<10$ & 510 & $<10$ & $<10$ \\
\hline 4-Nitroanliline & 10001.6 & P077 28000 & $<10$ & $<10$ & $<10$ & $\leq 10$ & $\leq 10$ & $<10$ \\
\hline 4,6 Dinitro-2-Mathylphenol & & NA & $<10$ & $\leq 10$ & $<10$ & $\leq 10$ & $\angle 10$ & $<10$ \\
\hline n-Nitroso-Diphenyl Amine & $156-10-5$ & $\overline{\mathrm{NA}}$ & $<10$ & $<10$ & $<10$ & $<10$ & $<10$ & $<10$ \\
\hline Azobenzens & 103333 & NA & $<10$ & $<10$ & $<10$ & 510 & $<10$ & $<10$ \\
\hline 4-Bromophenylphenyl Ether & 101.55 .3 & $4030 \quad 15000$ & $<10$ & $\leq 10$ & $<10$ & $<10$ & 510 & $<10$ \\
\hline Hexachlorobenzene & $118-741$ & 012726000 & $\leq 10$ & 410 & $<10$ & $\leq 10$ & $\leq 10$ & $<10$ \\
\hline Pentachlorophenol & $87-86-5$ & $0037 \quad 100000$ & $<10$ & $<10$ & $<10$ & $<10$ & $<10$ & $<10$ \\
\hline Phenanthrene & $85-01.8$ & NA & $<10$ & $<10$ & $<10$ & $<10$ & $<10$ & $<10$ \\
\hline Anthracene & $120-12-7$ & NA & $<10$ & $<10$ & $<10$ & $<0$ & $<10$ & $<10$ \\
\hline Carbazole & $86-74-8$ & NA & $<10$ & $<10$ & $<10$ & $<10$ & $<10$ & $<10$ \\
\hline Dibutyl phthalate & $84.74-2$ & 006928000 & $<10$ & $<10$ & $<10$ & $<10$ & $<10$ & $<10$ \\
\hline Fluoranthene & $206-440$ & 01208200 & $<10$ & $<10$ & $<10$ & $<10$ & $<10$ & $<10$ \\
\hline Pyrene & 129.000 & NA & $<10$ & $\leq 10$ & $<10$ & $<10$ & $<10$ & $<10$ \\
\hline Butylbenzyl phthalate & 85.68 .7 & NA & $<10$ & $<10$ & $<10$ & 510 & $<10$ & $<10$ \\
\hline Chrysene & $218-01-9$ & 40508200 & $<10$ & $<10$ & $<10$ & $\leqslant 10$ & $<10$ & $<10$ \\
\hline Benz[a]anthracene & $56-55-3$ & 00188200 & $<10$ & $<10$ & $\leqslant 10$ & $<10$ & $<10$ & $<10$ \\
\hline 3,3'-Dichlorobenzidine & $91-941$ & U073 NA & $\angle 10$ & $<10$ & $<10$ & $<10$ & $\leqslant 10$ & $<10$ \\
\hline bis (2-Ethylhexyl)Phthalate & $117-81-7$ & 002828000 & $<10$ & $<10$ & $34^{\circ}$ & 10 & 277 & 26 \\
\hline Dloctylphthalate & $117-840$ & U107 28000 & $<10$ & $<10$ & $<10$ & $\leq 10$ & $<10$ & $<10$ \\
\hline Benzo[b]fluoranthene & $205-99-2$ & NA & $<10$ & $<10$ & $<10$ & $<10$ & $<10$ & $<10$ \\
\hline Benzo[kfifuoranthene & $207-08-9$ & NA & $\angle 10$ & $\leq 10$ & $<10$ & $<10$ & $<10$ & $<10$ \\
\hline Benzolalpyrene & $50-32-\theta$ & 40228200 & $<10$ & $<10$ & $<10$ & $<10$ & $<10$ & $<10$ \\
\hline Indeno $[1,2,3$-cd]pyrene & 193.39 .5 & 01378200 & $<10$ & $<10$ & $<10$ & $<10$ & $<10$ & $<10$ \\
\hline Dlbenzo [ah]anthracene & 53.70 .3 & 00638200 & $<10$ & $<10$ & $\leq 10$ & $<10$ & $<10$ & $<10$ \\
\hline Benzolghijperylene & 191.24 .2 & NA & $\leq 10$ & $\leq 10$ & $<10$ & $<10$ & $<10$ & $<10$ \\
\hline
\end{tabular}

- Phthallates are commonly used to Increase the strength and chemical Inertness of plastics; and therefore are laboratory and sample contaminates. U indicates analyte falls mass spectral confirmation. 


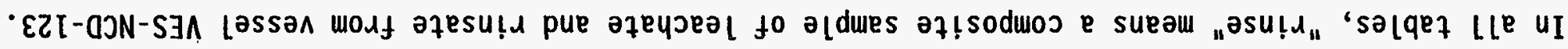

\begin{tabular}{|c|c|c|c|c|c|c|c|c|c|c|c|c|c|}
\hline ols & 015 & ats & ots & ots & OI: & OIt & 012 & ofs & oits & O1s & VN & $9906-002$ & 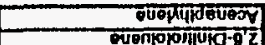 \\
\hline$\frac{012}{012}$ & $\frac{015}{012}$ & $\frac{g t s}{0 t s}$ & $\frac{t s}{d t^{3}}$ & 0013 & $\frac{\text { oft }}{\text { oit }}$ & $\frac{0.12}{0 i 2}$ & $\frac{\text { oft }}{\text { otis }}$ & $\frac{0 i s}{0 t s}$ & ols & $\frac{\text { ols }}{\text { oit }}$ & 0 ossoin & $202-009$ & 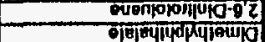 \\
\hline ots & ois & Oा? & ठี่ & ots & ots & ots & $\frac{2}{\partial t}$ & ofts & $\frac{15}{0 t s}$ & $01 \%$ & $\frac{10011}{\mathrm{~N}}$ & 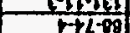 & क्षा \\
\hline Dis & 012 & Oit) & Dis & (0) & Dis & oi) & oir & ois & of & of & golton & 20516 & 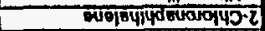 \\
\hline ot? & ôts & o1s & $\overline{017}$ & oit & ois & ots & ots & ot? & oits & ois & $0002 \mathrm{CH00}$ & 3000 & 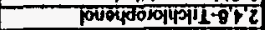 \\
\hline obs & ois & ois & o15 & of & ol: & ols & OIs & ois & oit & olp & $00000+11000$ & & W कानासम \\
\hline$\frac{\theta t s}{0 t s}$ & of & OII & ois & ois & 012 & ois & $\frac{15}{015}$ & $\frac{015}{15}$ & $\frac{015}{612}$ & ots & isoein & $\frac{p-2+4}{0,1-1}$ & 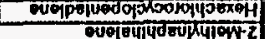 \\
\hline$\frac{a j}{0 t^{2}}$ & $\frac{012}{0.12}$ & 然 & $\frac{a p}{d t}$ & $\frac{g_{1}}{d t}$ & $\frac{0 i s}{d i}$ & oits & ois & $\frac{0 t 5}{015}$ & $\frac{0 i 3}{012}$ & $\frac{018}{015}$ & $\frac{m}{m}$ & 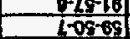 & 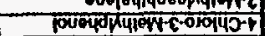 \\
\hline ots & ol: & Ol> & ots & ot> & Dl: & Ot: & Ols & ots & 01. & Ol: & sageln & $500-19$ & 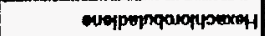 \\
\hline Dis & 015 & 015 & 012 & ot? & का० & का: & Dा? & Oㄴ? & Oा & ots & $09+120 d$ & giropi & 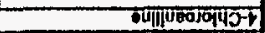 \\
\hline ol 3 & 012 & 01. & ois & ofs & Oा? & oit: & 01. & ois & Ols & dis & बsingin & $60 t-16$ & 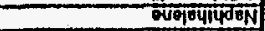 \\
\hline 012 & 012 & 013 & ots & Ois & 015 & ais & 015 & ois & O1s & ots & $\sqrt{11}$ & $1-28-021$ & 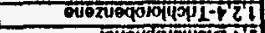 \\
\hline ots & 015 & Of. & Ols & Of: & 015 & 012 & ol. & 018 & 013 & ols & Dison & z-68021 & pot \\
\hline $01 ?$ & 015 & ols & Ols & DIP & 015 & of & 015 & & OIS & OIt & geloln & & D. \\
\hline ols & 015 & als & O12 & olz & of & OI: & O12 & Dit2 & AGE & Aib & $\sqrt{n}$ & SGL & मिएक्युत \\
\hline ols & ol: & 0l: & Aot & 01. & Ave & 196 & 012 & net & $01 \%$ & 01. & $\mathbf{w}$ & & 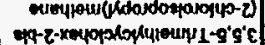 \\
\hline 015 & ols & Ol $>$ & Ot. & ols & Ol: & ol. & O1. & 012 & ol: & 01. & कृषात & $\varepsilon-96-96$ & mozuogojur \\
\hline 0it. & 01. & 01. & 01. & Dis & Ol. & ols & ol. & Ots & Ol: & Ol: & sginin & Iन & 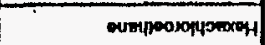 \\
\hline 0is & 015 & $0 i 2$ & oit & Dits & Dis & ois & 012 & OtS & 012 & 012 & vin & 109001 & DTI \\
\hline OII & Ols & O1> & O1) & DIs & O1: & oll & ots & ols & 015 & ols & $\cot 1$ & & 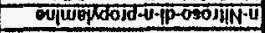 \\
\hline Ot: & Ol= & al: & Ol: & ols & ol: & Ol: & ol? & ol: & 01: & Oi. & 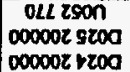 & & \\
\hline ots & 012 & ols & ol> & ots & ols & ol: & Ol> & ois & ob) & ol: & 0112 & Le+ses & ali \\
\hline Ois: & 012 & OTs & Oit & Ots & ols & O12 & ôts & Dit? & Ol= & OAs & & & 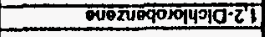 \\
\hline 01x & ols & ots & 01. & Dit. & ols & ols & ol: & ot> & ols & ol. & & & 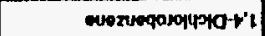 \\
\hline OIt & Ofts & of & 012 & 013 & ots & oit & ols & Ol) & 018 & & & & 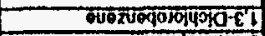 \\
\hline 015 & 015 & as & ots & 015 & o1 & of & O15 & of: & of & oIs & & & 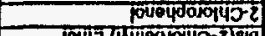 \\
\hline ofs & 015 & ofs & olr & OIt & 015 & i & oit & ofs & & of 2 & & & ग्रा1 $(0 \times 41000145-2)$ \\
\hline ofs & O1s & ois & oft & 015 & 012 & $01:$ & of & ol & 015 & 이 & & & \\
\hline 아고 & Ols & 이 & 015 & ots & Q1: & OID & dit & ols & of: & ots & & & \\
\hline Oif & QI? & Q1? & O1? & Ols & 012 & Qls & ols & Ol2 & o1s & F & & & 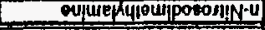 \\
\hline alozeroto & LelEO+6 & $150+8$ & $2 z 1160-6$ & $241.00+6$ & $\begin{array}{l}\text { Pthocoto } \\
\text { eroofidno }\end{array}$ & seort & oszzo-16 & ostzo+6 & $210 z 20$ on & $210220-8$ & & roquinow SVO & 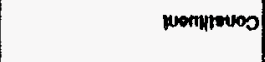 \\
\hline 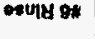 & omvilas st & bonvas: & envily the & onum we & onufy en: & owuly E: & ompla & orous $2 \pi$ & omplatis & multit & Noltęnesy & & \\
\hline
\end{tabular}




\section{Table 24 (continued).}

\begin{tabular}{|c|c|c|c|c|c|c|c|c|c|c|c|c|c|}
\hline Conselthent & CAs Numbor & $\begin{array}{l}\text { Rogulatory } \\
\text { Limki }\end{array}$ & $\begin{array}{l}\text { AsRines } \\
\text { 94.022012 }\end{array}$ & $\begin{array}{l}\text { "1 Rines } \\
\text { Duplleato } \\
\text { O4.022012 }\end{array}$ & $\begin{array}{l}12 \text { Rines } \\
\text { 94-02250 }\end{array}$ & $\begin{array}{l}\text { OR Rines } \\
\text { Duplicate } \\
\text { O4-02250 }\end{array}$ & 94030415 & $\begin{array}{l}\text { is Rinsea } \\
\text { Dupticato } \\
\text { o4-03041 }\end{array}$ & $\begin{array}{l}41 \mathrm{R} \ln 80 \\
\text { O4-031122 }\end{array}$ & $\begin{array}{l}\text { H4 Rines } \\
\text { Dupllowte } \\
\text { O4-031122 }\end{array}$ & 0403167 & $\begin{array}{l}\text { W5 Rinsen } \\
\text { Duplloale } \\
\text { O403107 }\end{array}$ & O4032810 \\
\hline 3-NHlloaniline & & & $5+10$ & 310 & 510 & $410^{\circ}$ & 310 & $\frac{310}{610}$ & $\frac{310}{10}$ & 380 & $\leq 10$ & 210 & $310^{\circ}$ \\
\hline $\begin{array}{l}\text { Acenaphithene } \\
\text { 2.4-Dintirophenol }\end{array}$ & $\frac{3.32-9}{1-256}$ & $\frac{M A}{P 04812}$ & $\frac{410}{86 Y}$ & $\frac{410}{110}$ & $\frac{410}{16}$ & $\frac{4+10}{510}$ & $\leq 10$ & $<10$ & $<10$ & $\frac{40}{39}$ & $\frac{510}{510}$ & $\frac{<10}{230}$ & $\frac{310}{210}$ \\
\hline 4Niltochend & $00-02-7$ & 0170120 & 220 & 290 & 510 & $\frac{90}{410}$ & 510 & 210 & 510 & $<10$ & रा0 & 910 & 210 \\
\hline Dibenzofuran & $32-64.56$ & $\mathrm{MA}$ & $\leqslant 10$ & .10 & .10 & +10 & $\times 10$ & $\leq 10$ & 510 & 410 & $\$ 10$ & $\$ 10$ & $\$ 10$ \\
\hline 2,4-Dinlurodotuans & & D030 130 & $<10$ & $<10$ & $<10$ & $<10$ & $<10$ & $<10$ & $<10$ & $<10$ & $<10$ & $<10$ & $<10$ \\
\hline Dlothrighilhalate & $60-2$ & 4068200 & $\$ 10$ & 510 & 210 & 510 & $\$ 10$ & 410 & 810 & $<10$ & 510 & $<10$ & $\leqslant 10$ \\
\hline & $206-44-0$ & MA & 310 & 510 & 510 & $\leq 10$ & $\leqslant 10$ & $\leqslant 10$ & 510 & $\leqslant 10$ & 810 & 810 & 310 \\
\hline 4.Chlorophondophand Elh or & $7005-723$ & $M R$ & $\$ 10$ & $\$ 10$ & 810 & $\leqslant 10$ & $\leqslant 10$ & 810 & 410 & 510 & 310 & 510 & $\$ 10$ \\
\hline 4-Niliroaniline & $10001-6$ & P07726 & 810 & $\leq 10$ & 510 & 510 & $\leqslant 10$ & sio & $\leqslant 10$ & 10 & 310 & $\leq 10$ & 810 \\
\hline n-Nilroso-Diphond Aming & $156-10-5$ & NA & $\leq 10$ & $<10$ & 410 & 410 & 510 & $<10$ & $\$ 10$ & 510 & $\$ 10$ & 510 & 410 \\
\hline Azobonzene & $103-333$ & MA & $5+10$ & 510 & 810 & 50 & $\$ 10$ & $\leqslant 10$ & 810 & $\leqslant 10$ & 310 & 510 & $\leq 10$ \\
\hline 2-Molby-1,6-Dinifophenal & $\frac{505-71-5}{150.56}$ & NA & 510 & $\leq 10$ & $\frac{610}{10}$ & 510 & $\leq 10$ & 510 & 510 & $\leq 10$ & $\frac{<10}{410}$ & $\frac{510}{510}$ & $\frac{<10}{610}$ \\
\hline 4- Bromophendphend Eller & $101.55 \cdot 3$ & 403055 & $<10$ & 410 & & 510 & & $s+0$ & 410 & $\leq 10$ & $\leq 10$ & 510 & $\$ 10$ \\
\hline Hexomathorobenzens & & $\begin{array}{l}D 032130 \\
u 1755\end{array}$ & $<10$ & $<10$ & $<10$ & 410 & $<10$ & $<10$ & 410 & $<10$ & $<40$ & $<10$ & $<10$ \\
\hline Panlachlorophanal & 865 & 0037100000 & 510 & $\$ 10$ & $\leq 10$ & $<10$ & $<10$ & $<10$ & $\leqslant 10$ & $\leqslant 10$ & $\leq 10$ & $\leqslant 10$ & 310 \\
\hline Carbazolo & 7748 & MA & 410 & 510 & 310 & 510 & $<10$ & $<10$ & & 510 & $2+10$ & $<10$ & $<10$ \\
\hline Phananthrene & 85.018 & NA & 510 & 510 & 510 & 810 & 510 & $\leqslant 10$ & 10 & 510 & 510 & -510 & 50 \\
\hline Anthrocene & $12 a-12.7$ & $\mathrm{MQ}$ & 510 & $\$ 10$ & 3io & 810 & $\$ 10$ & 310 & & $<10$ & $<10$ & $\$ 10$ & 310 \\
\hline Diturylyohthalato & 84742 & 006957 & 410 & 510 & 510 & $\$ 10$ & $\$ 10$ & 410 & 410 & 510 & $\$ 10$ & 510 & 510 \\
\hline Bublbenzuphifigalale & $65-68-7$ & NA & 510 & $\$ 10$ & & $\$ 10$ & $\$ 10$ & $\leqslant 10$ & & $<10$ & 310 & 310 & 410 \\
\hline Fluegnallerie & $200-440$ & U12060 & $\$ 10$ & 210 & $\leq 10$ & 510 & 310 & 510 & 510 & 210 & 310 & $\leq 10$ & $\leq 10$ \\
\hline & 129000 & $\mathrm{M}$ & 410 & 510 & 510 & .10 & .10 & 410 & 510 & 510 & 510 & .10 & 50 \\
\hline 3,3-Dichiorobonzldine & $91.94+1$ & 4073 & 410 & 410 & $\leq 10$ & 510 & 510 & $\leq 10$ & $\$ 10$ & 410 & $\leqslant 10$ & 310 & 510 \\
\hline Eanziglentifirecene & $56-553$ & Uol1659 & 810 & -10 & 310 & 410 & 510 & 410 & $\frac{810}{10}$ & 50 & 510 & 510 & 510 \\
\hline Chopoune & 2(B-01-0 & 005059 & 510 & 510 & 510 & 510 & .10 & 510 & 510 & $<10$ & 310 & $\$ 10$ & 510 \\
\hline blec(2-Ethytroxy) Philhatalo & 117.35:-7 & 0,028280 & 1604 & 810 & & & 10 & & & 78 & 69 & & $10 Y$ \\
\hline 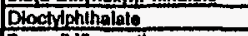 & $\frac{117-840}{110}$ & $M$ & 810 & 210 & 310 & 410 & -10 & 310 & 210 & 410 & 410 & $\leq 10$ & $<10$ \\
\hline Benzoditiluaranithene & & $\mathrm{M}$ & 310 & 210 & 510 & 510 & 510 & 410 & 10 & 810 & $\$ 10$ & 510 & $\leq 10$ \\
\hline 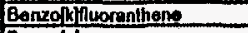 & & NA & 310 & 510 & 510 & $\$ 10$ & 510 & $<10$ & 310 & $\leq 10$ & 51 & $<10$ & $\leq 10$ \\
\hline Benzololprene & 50,326 & 0,02261 & 410 & & 210 & $=10$ & 510 & $\leq 10$ & 410 & 410 & 510 & $\leq 10$ & $\$ 10$ \\
\hline ond i, 2, 3alpontene & & 01376.6 & 510 & & 510 & 510 & & $\leqslant 10$ & 10 & & & 10. & 510 \\
\hline Dibonzof ohlanthrease & $\frac{53-70,3}{191-21-2}$ & $\frac{00355}{M}$ & $\frac{<10}{810}$ & $\frac{410}{510}$ & $\frac{310}{510}$ & $\frac{<10}{10}$ & $\frac{210}{610}$ & $\frac{-10}{510}$ & $\frac{410}{410}$ & $\frac{310}{510}$ & $\frac{10}{<10}$ & $\frac{410}{410}$ & $\frac{<10}{510}$ \\
\hline
\end{tabular}


Table 25. HEPA filter leaching system (HFLS) initial six filter last process rinse sample.

\begin{tabular}{|c|c|c|c|c|c|c|c|c|}
\hline & Constituent & $\begin{array}{c}\text { Regulatory } \\
\text { Limit }\end{array}$ & $\begin{array}{c}\text { Filter \#1 } \\
94-022010 \\
(\mathrm{mg} / 1) \\
\end{array}$ & $\begin{array}{c}\text { Filter \#2 } \\
94-022511 \\
(\mathrm{mg} / 1)\end{array}$ & $\begin{array}{c}\text { Filter \#3 } \\
94-030417 \\
(\mathrm{mg} / 1)\end{array}$ & $\begin{array}{c}\text { Filter \#4 } \\
94-031124 \\
(\mathrm{mg} / 1)\end{array}$ & $\begin{array}{c}\text { Filter } \# 5 \\
94-031611 \\
(\mathrm{mg} / 1) \\
\end{array}$ & $\begin{array}{c}\text { Filter \#6 } \\
94-032821 \\
(\mathrm{mg} / 1) \\
\end{array}$ \\
\hline & Arsenic & $5 \mathrm{mg} / 1$ & $<0.170$ & $<0.121$ & $<0.671$ & $<0.679$ & $\begin{array}{c}\text { not } \\
\text { completed } \\
\end{array}$ & $<0.681$ \\
\hline & Barium & $100 \mathrm{mg} / 1$ & $<0.219$ & $<0.156$ & $<0.865$ & $<0.879$ & $\begin{array}{c}\text { not } \\
\text { completed } \\
\end{array}$ & $<0.878$ \\
\hline & Cadmium & $1 \mathrm{mg} / 1$ & $<0.216$ & $<1.19$ & $<0.853$ & $<0.863$ & $\begin{array}{c}\text { not } \\
\text { completed }\end{array}$ & 0.902 \\
\hline & Chromium & $5 \mathrm{mg} / 1$ & 0.212 & $<1.48$ & $<0.820$ & $<0.831$ & $\begin{array}{c}\text { not } \\
\text { completed }\end{array}$ & 2.61 \\
\hline & Lead & $5 \mathrm{mg} / 1$ & $<0.143$ & $<1.02$ & $<0.566$ & $<0.573$ & $\begin{array}{c}\text { not } \\
\text { completed } \\
\end{array}$ & $<0.575$ \\
\hline & Mercury & $0.2 \mathrm{mg} / 1$ & $<0.0002$ & $<0.2$ & 0.026 & 0.46 & 0.46 & 0.36 \\
\hline . & Selenium & $1 \mathrm{mg} / \mathrm{l}$ & $<0.149$ & $<0.826$ & $<0.590$ & $<0.597$ & $\begin{array}{c}\text { not } \\
\text { completed }\end{array}$ & $<0.599$ \\
\hline & Silver & $5 \mathrm{mg} / \mathrm{l}$ & $<0.194$ & $<1.38$ & $<0.765$ & $<0.775$ & $\begin{array}{c}\text { not } \\
\text { completed }\end{array}$ & $<0.777$ \\
\hline
\end{tabular}

Preliminary (4/4/94) 


\section{ApPendix B}

Design of Leach Basket and Support frame 
. 


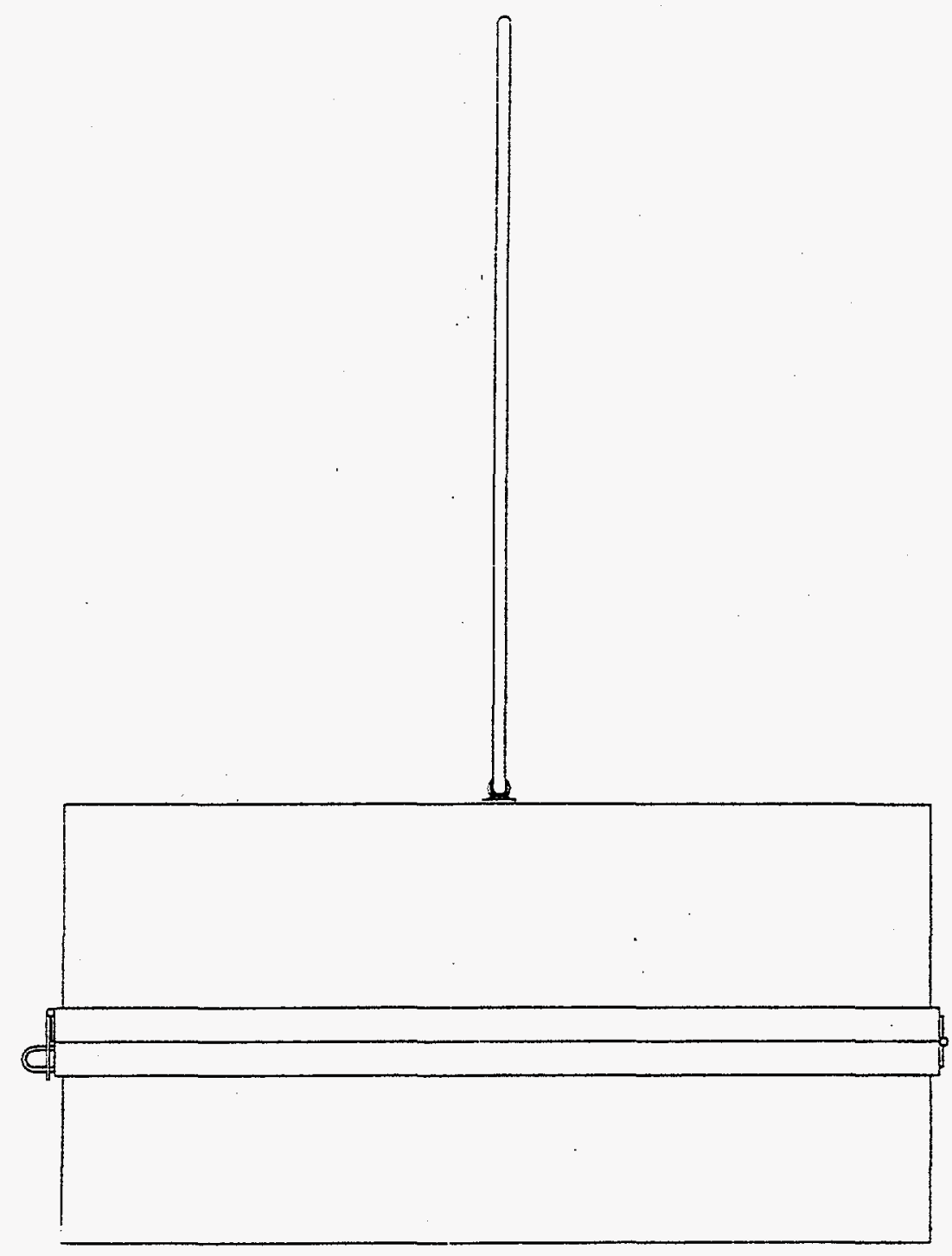

Figure B-1. Sketch of assembled basket.

$$
\text { B-3 }
$$




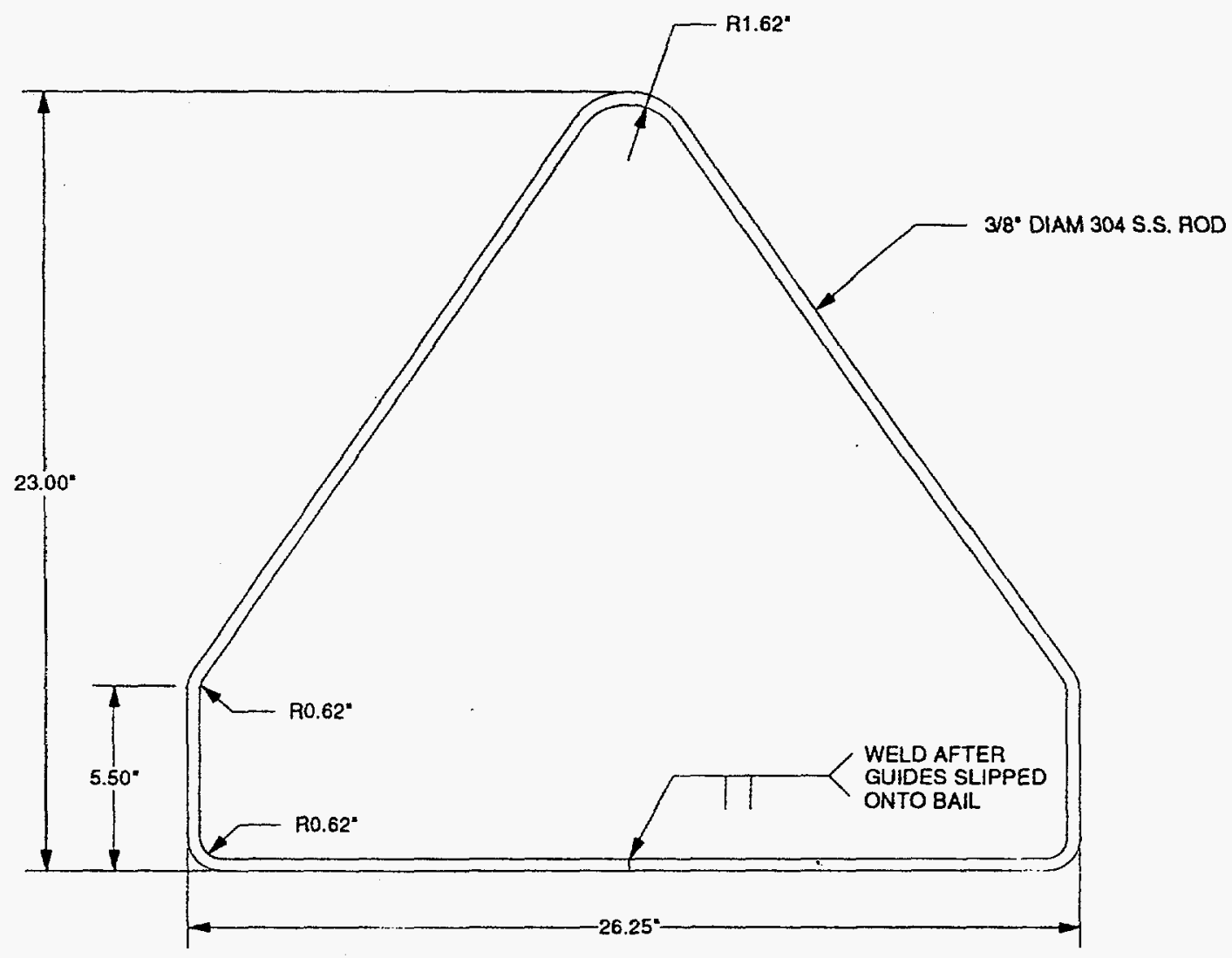

Figure B-2. Sketch of basket bail. 


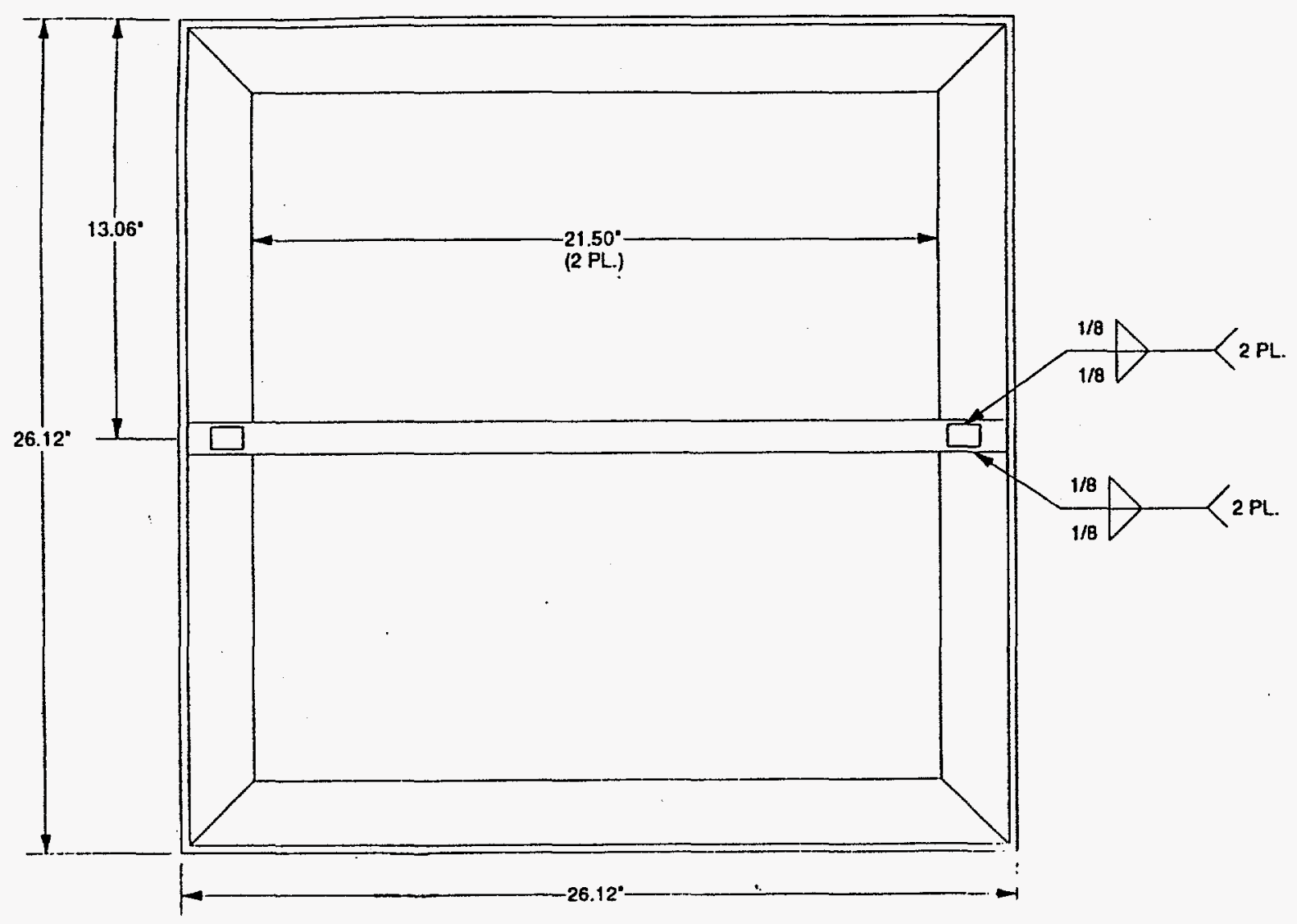

Figure B-3. Plan view of basket top assembly (screen and bail omitted for clarity).

B-5 


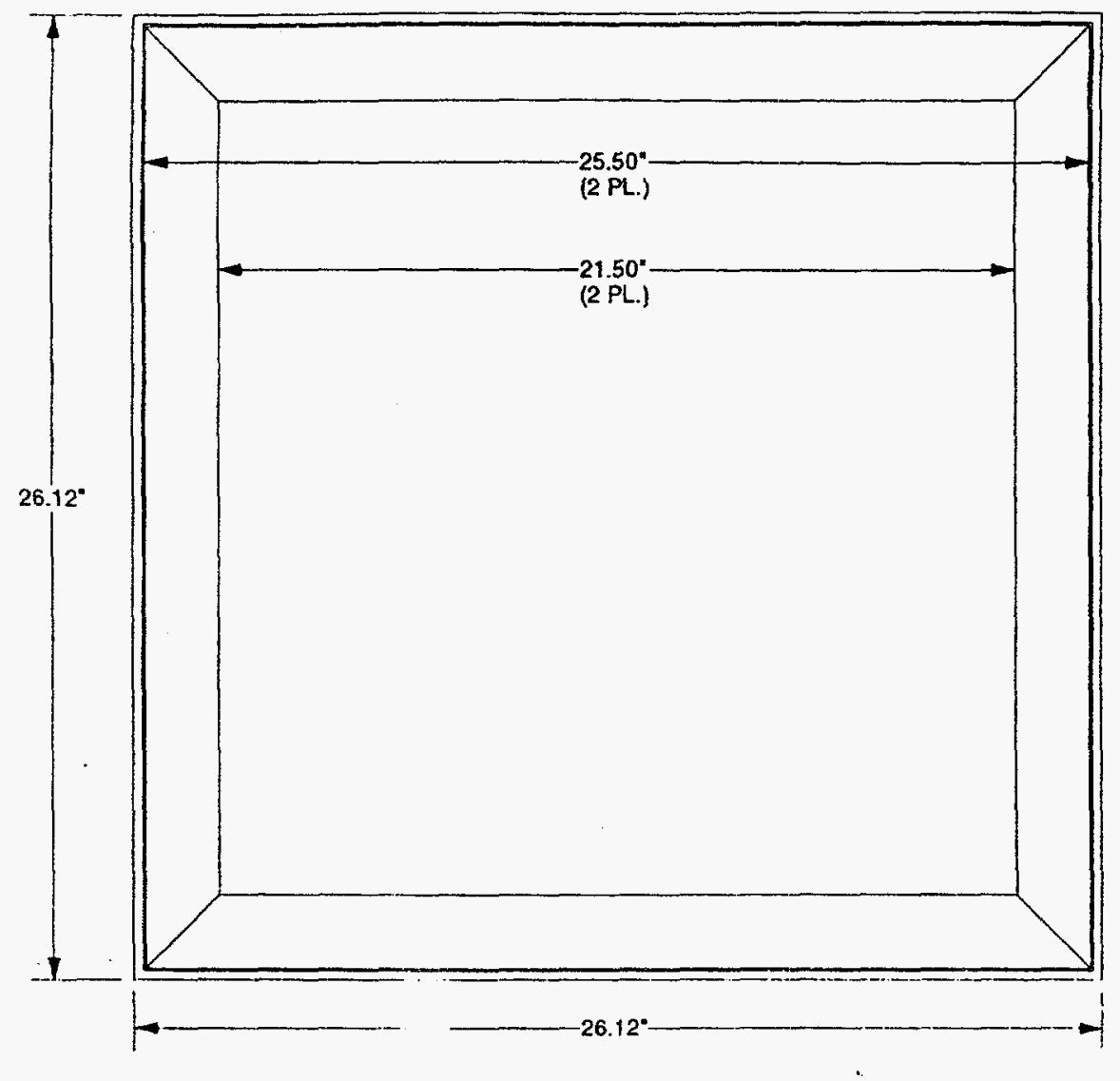

Figure B-4. Plan view of base assembly (screen omitted for clarity).

$$
\text { B-6 }
$$




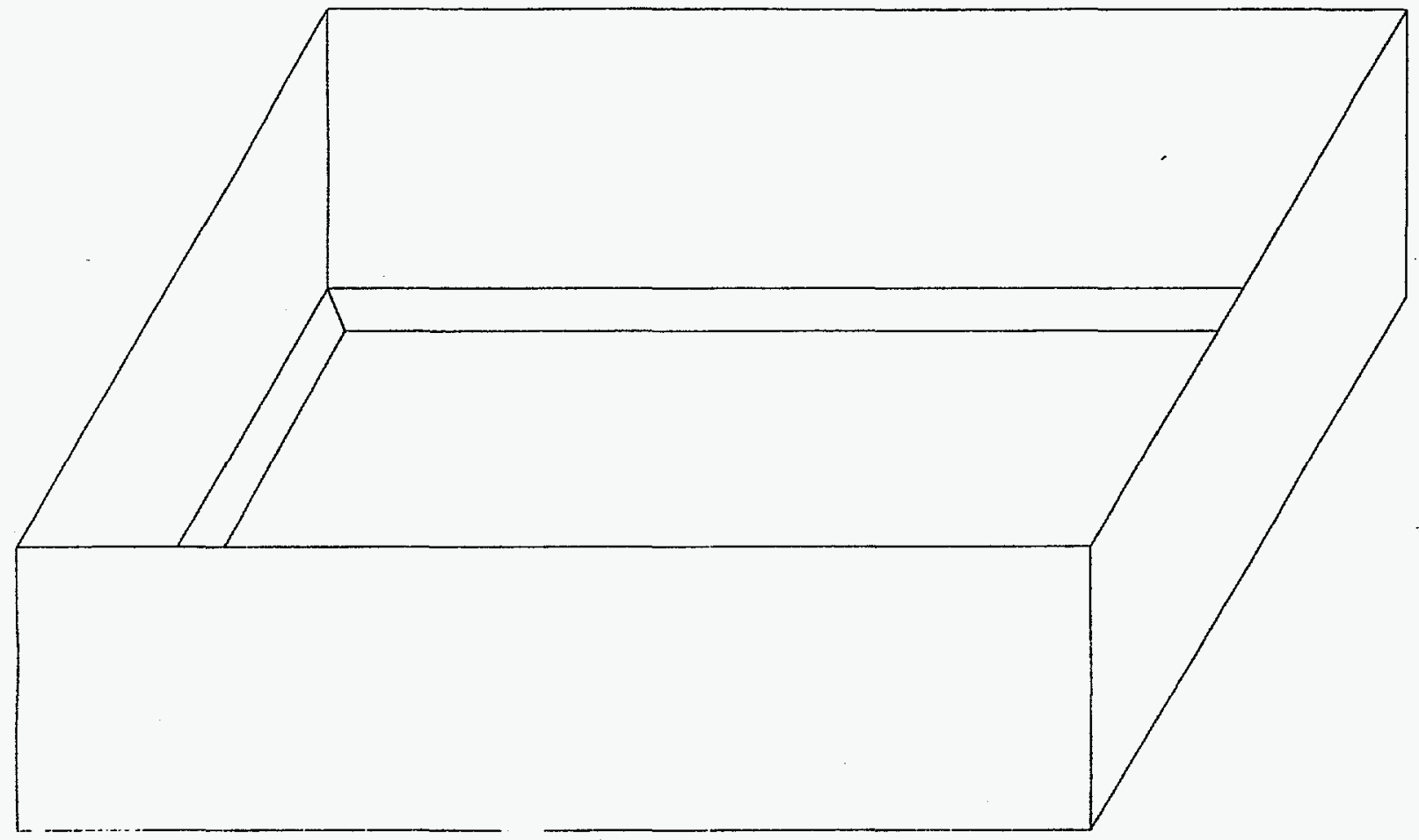

Figure B-5. Isometric sketch of folded sheet metal box.

B-7 


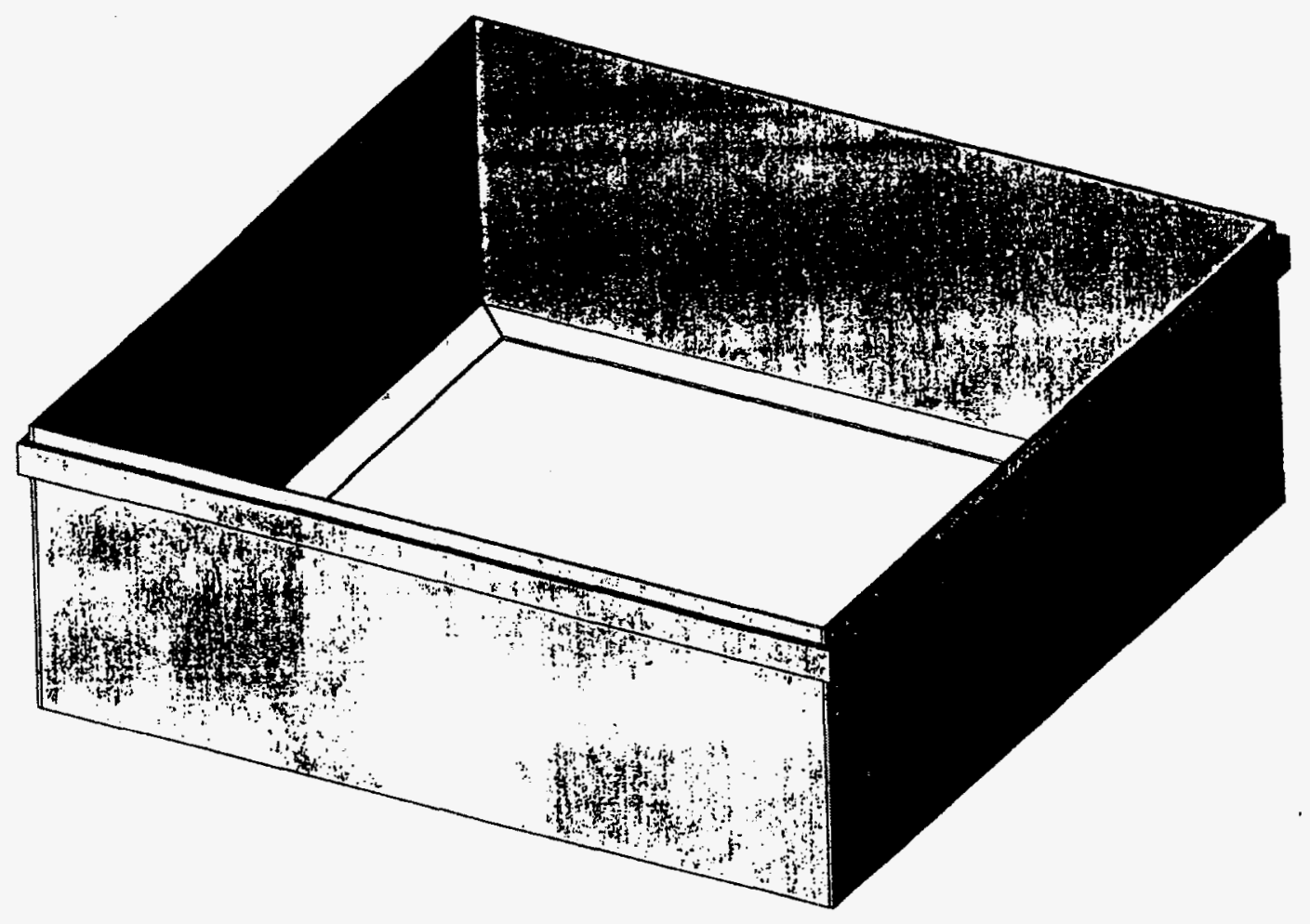

Figure B-6. 3-D Isometric view of base assembly (screen omitted for clarity). 


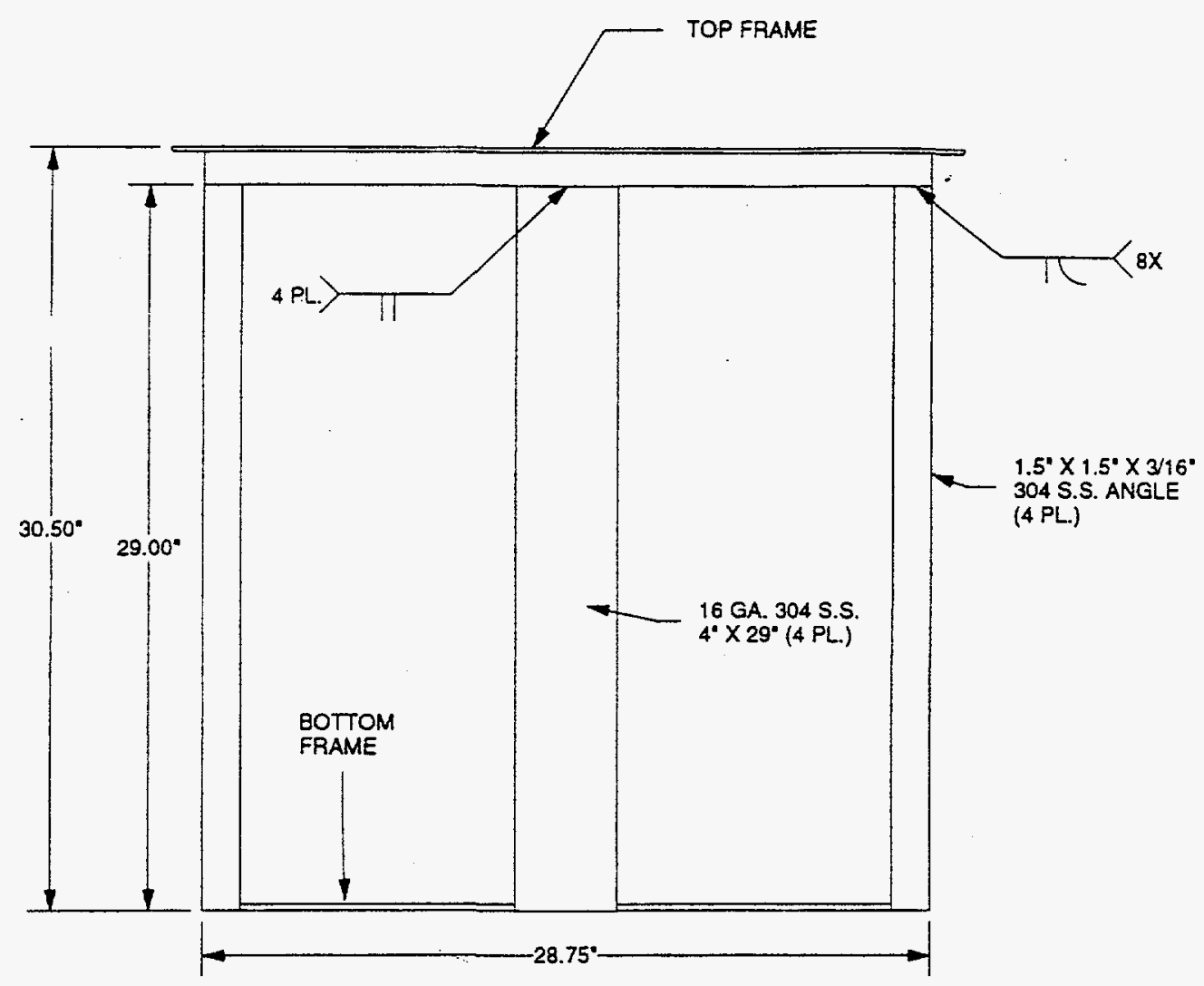

Figure B-7. Side view of basket support assembly (bail omitted for clarity). 


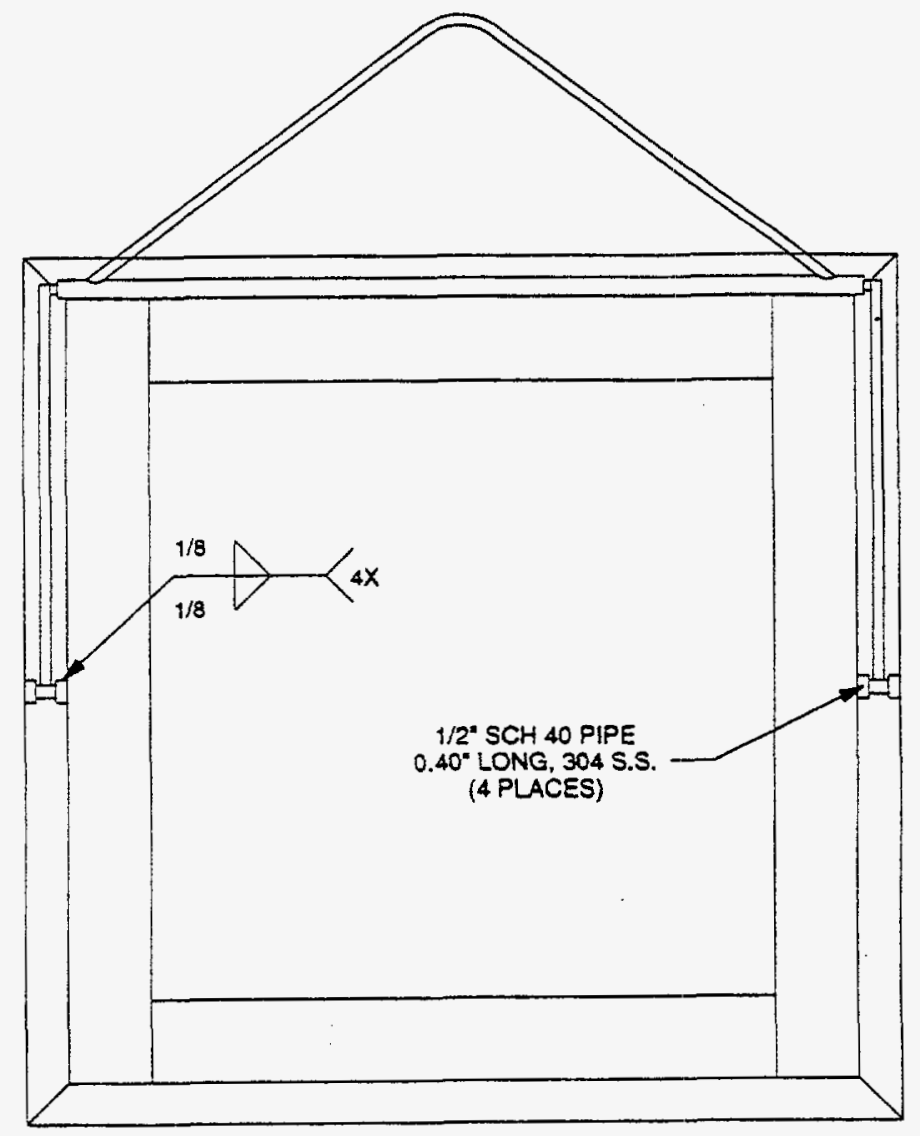

Figure B-8. Top view of basket support assembly. 


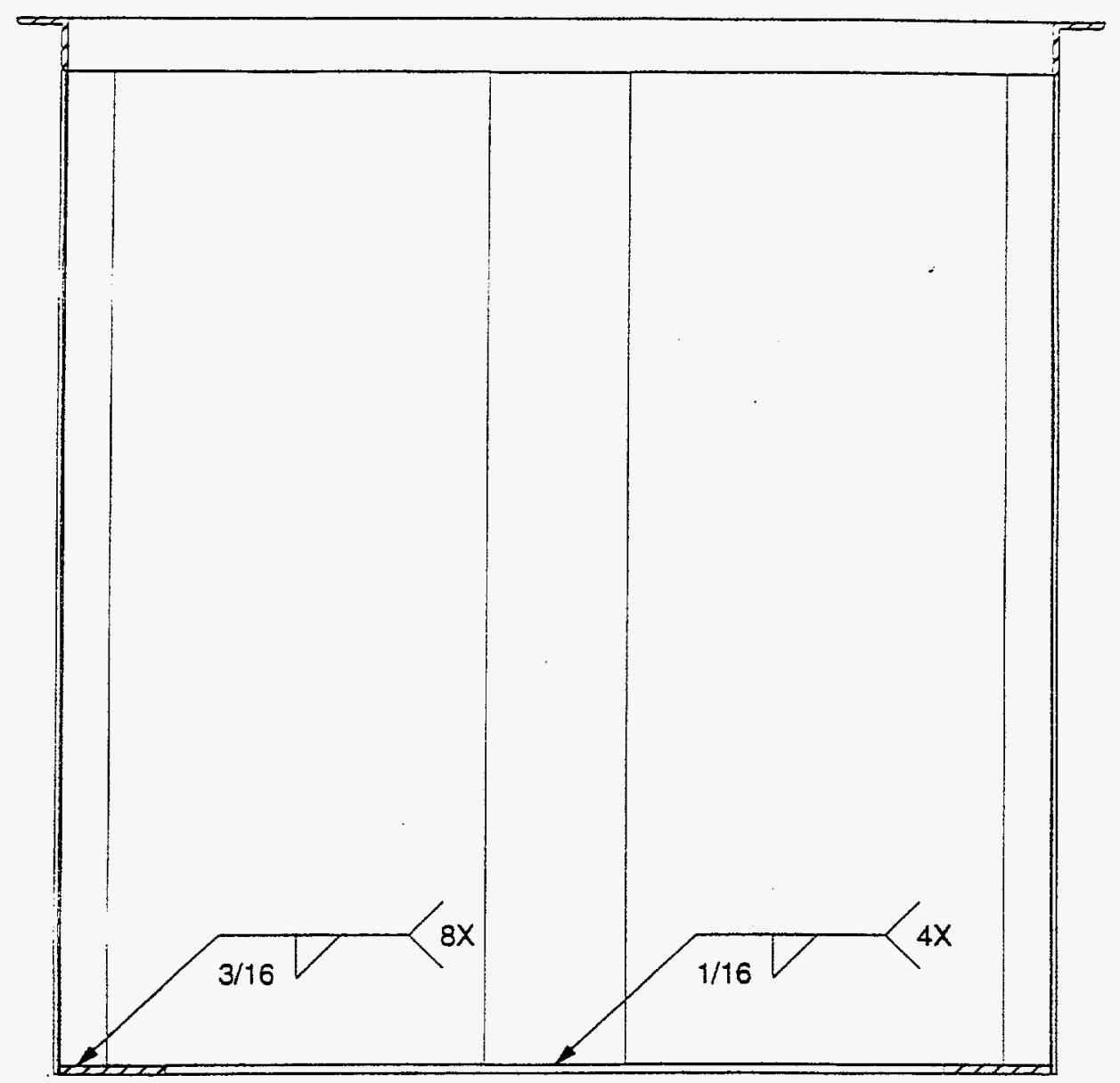

Figure B-9. Section view through side of basket support (bail omitted).

\section{B-11}




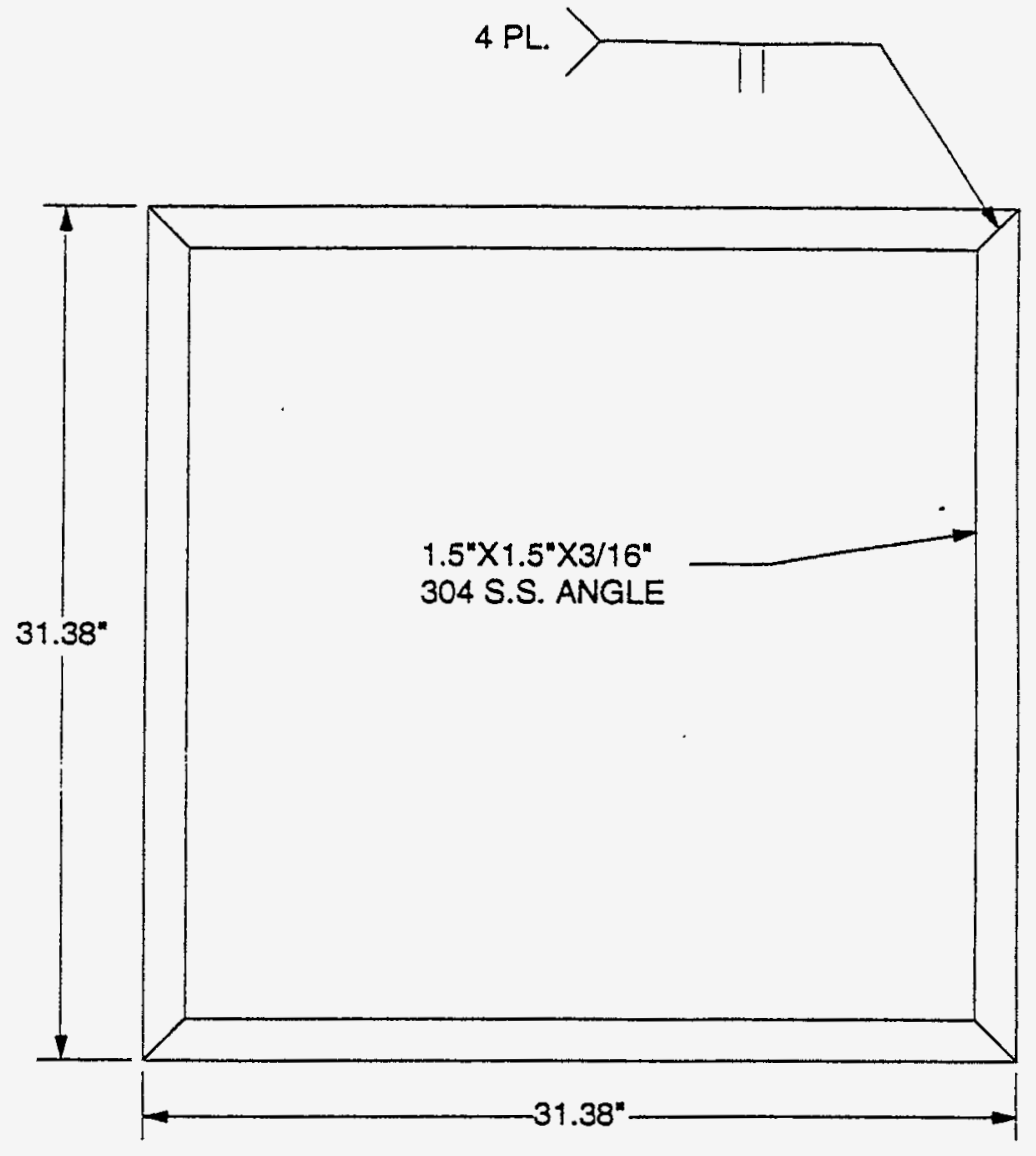

Figure B-10. Detail of top frame of basket support. 


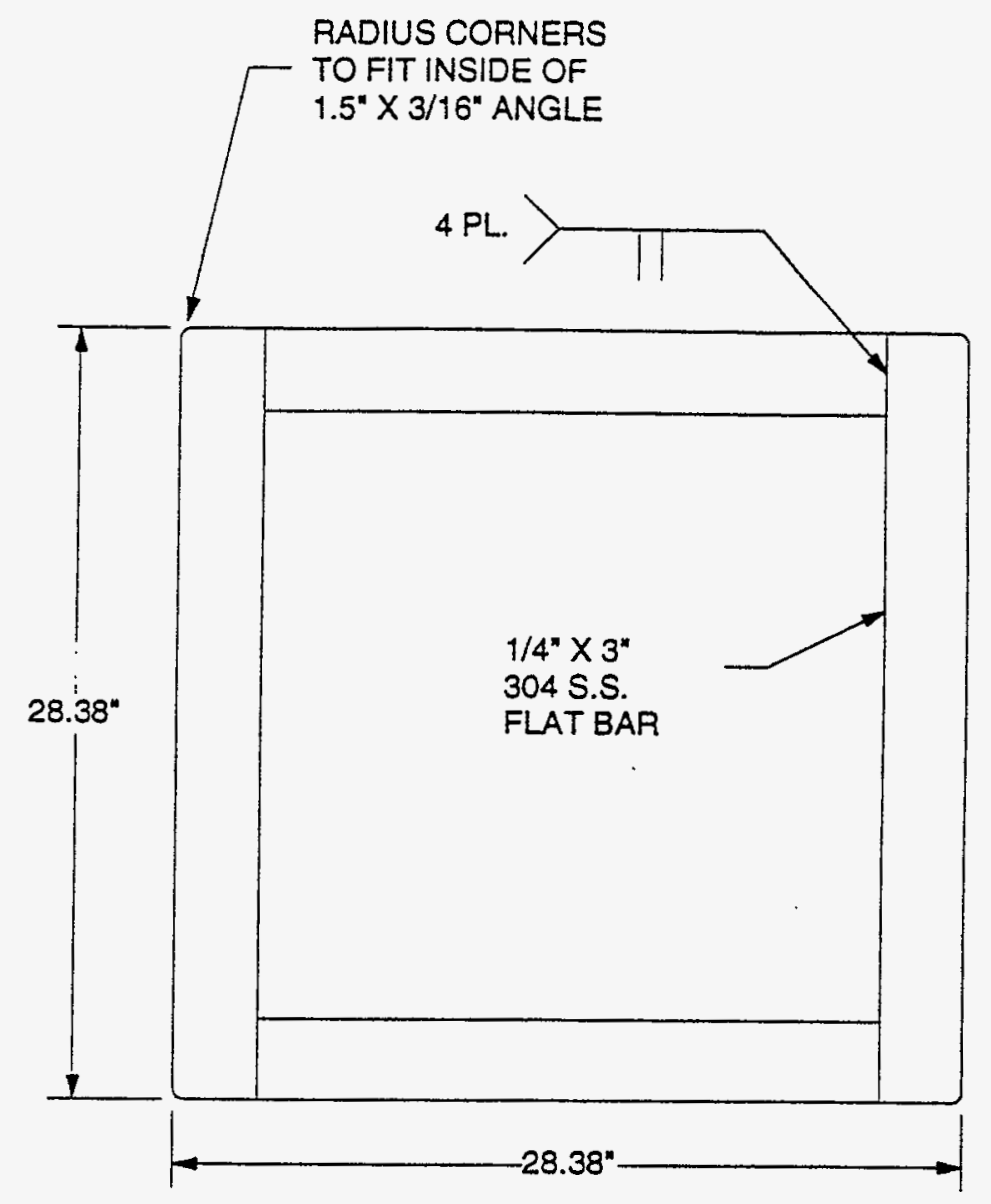

Figure B-11. Detail of bottom frame of basket support. 


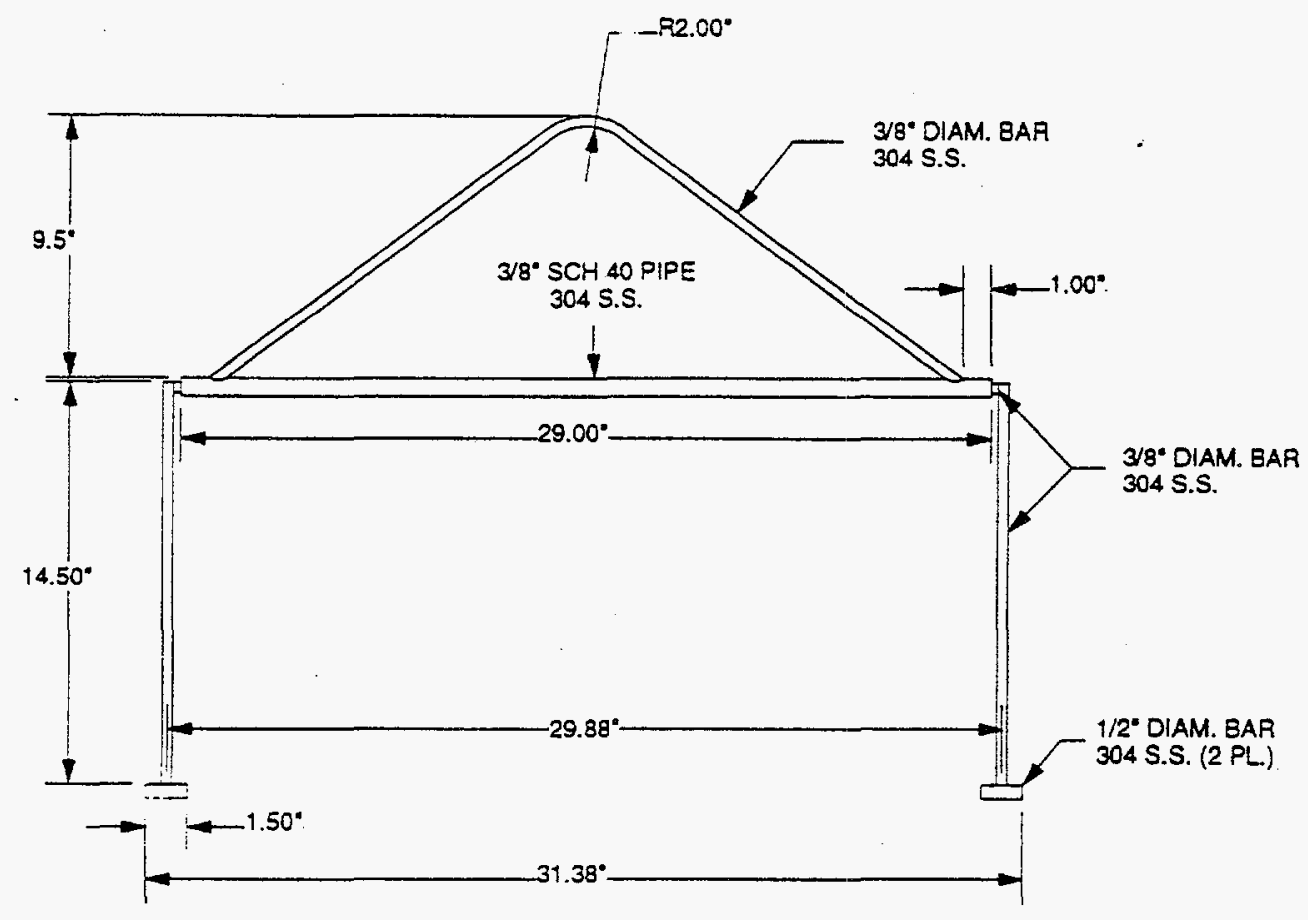

Figure B-12. Sketch of bail assembly for basket support. 